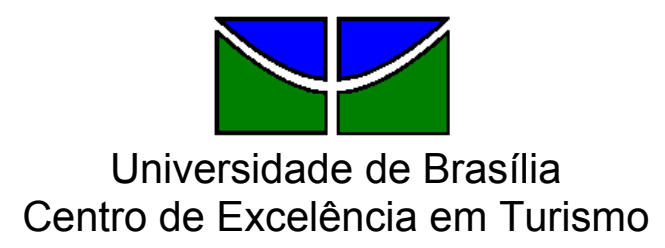

Pós-graduação Lato Sensu

Curso de Especialização em Gestão de Negócios em Turismo

\title{
BRASIL COMO DESTINO DE VIAGENS DE INCENTIVO
}

Cinthia Fernanda Marques da Silva

Brasília - 2009 


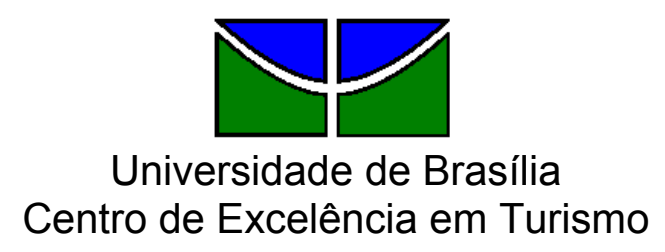

Pós-graduação Lato Sensu

Curso de Especialização em Gestão de Negócios em Turismo

\section{BRASIL COMO DESTINO DE VIAGENS DE INCENTIVO}

Cinthia Fernanda Marques da Silva

Professor Orientador: Dr. Gilson Zehetmeyer Borda

Monografia apresentada ao Centro de Excelência em Turismo da Universidade de Brasília - CET/UnB, como requisito parcial à obtenção do grau de Especialista em Gestão de Negócios em Turismo.

Brasília - 2009 
Silva, Cinthia F. M.

Brasil como destino de Incentivo / Cinthia Silva. - Brasília, 2009.

$96 \mathrm{f}$ : il.color

Monografia (especialização) - Universidade de Brasília, Centro de Excelência em Turismo, 2009.

Orientador: Gilson Zehetmeyer Borda.

1. Turismo. 2. Incentivo. 3. Brasil. I. Título 
Universidade de Brasília

Centro de Excelência em Turismo

Pós-graduação Lato Sensu

Curso de Especialização em Gestão de Negócios em Turismo

\section{BRASIL COMO DESTINO DE INCENTIVO}

Cinthia Fernanda Marques da Silva

Aprovado por:

Professor orientador: Dr.Gilson Zehetmeyer Borda

Professor Avaliador: Ms Mara Flora

Professor Avaliador: Ms Carla Márcia RodriguesTenser

Brasília, 28 de julho de 2009 
Dedico esta pesquisa a todos que incentivam e motivam pessoas a serem seres cada vez melhores. 
Agradeço a Deus, meu Pai guiador. Aos meus familiares e amigos, que tiveram paciência comigo nesta fase da minha vida. Ao meu orientador, que não poupou esforços para me instruir. 


\section{RESUMO}

Este trabalho é um estudo sobre o segmento de Turismo de Incentivo, mostrando suas motivações, origem e evolução. Relata-se brevemente as principais características desse segmento e algumas de suas peculiaridades, obtidas por meio de pesquisa bibliográfica. Também foi analisada a opinião do trade por meio de entrevistas realizadas com 7 representantes da cadeia produtiva do turismo brasileiro. O estudo tem o intuito de identificar a vocação do Brasil como destino de incentivo e a diversidade cultural do país é o principal produto a ser trabalhado nesse segmento. Por fim, apresenta-se algumas sugestões para dinamizar 0 Turismo de Incentivo no país, sendo a principal delas a criação de um Bureau de Incentivo.

Palavras- chave :

1. Motivação

2. Turismo de Incentivo

3. Empresas 


\begin{abstract}
This paper carries through on the segment of Tourism of Incentives, showing its motivation, beginning and evolution. It describes its characteristics briefly and some of its peculiarities obtained through literature. The view of the trade was also analyzed through interviews with 7 representatives of the Brazilian productive chain of tourism. The study has the aim in analyzing which is the Brazil's vocation as an incentive destination and the cultural diversity of the country is the main product to be working in that segment. Finally, it is suggested some actions to improve the Tourism of Incentive in Brazil, the main one was the creation of a Bureau of Incentive.
\end{abstract}

Keywords:

1. Motivation

2 Incentive Tourism

3. Companies 


\section{SUMÁRIO}

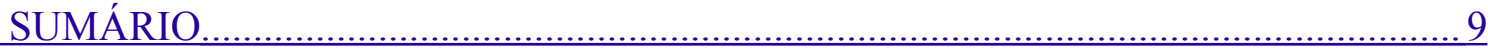

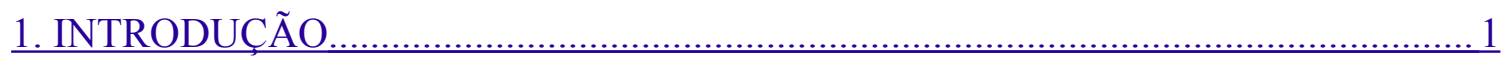

1.1. Contextualização do Assunto / Apresentação e delimitação do tema..........................1

1.2. Descrição da situação problemática / Formulação do problema ................................ 2

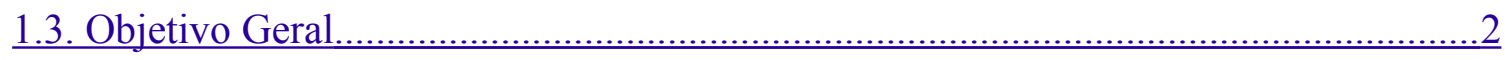

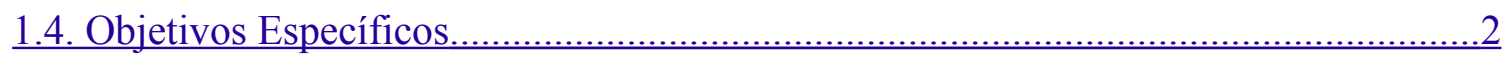

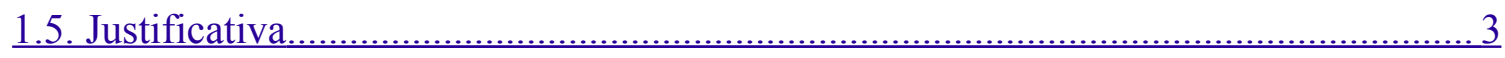

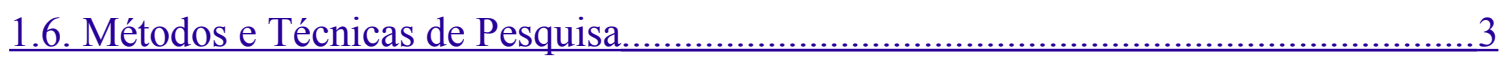

1.7. Estrutura e Organização do Trabalho............................................................... 4

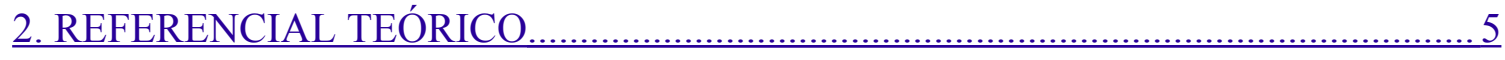

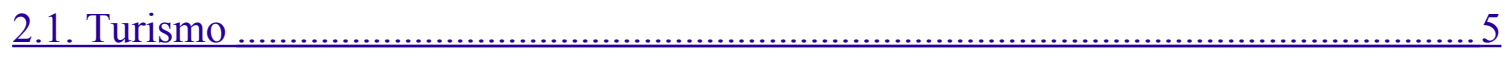

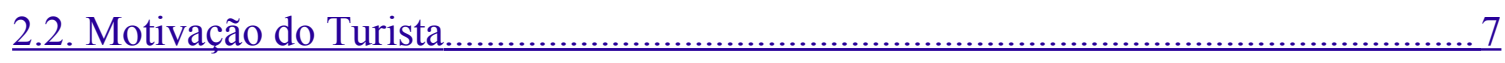

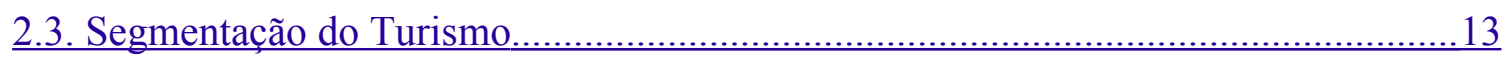

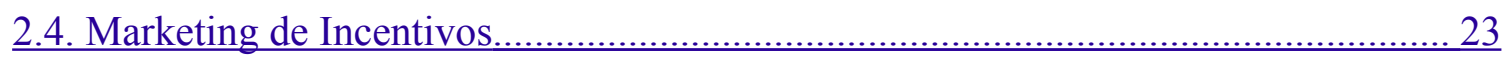

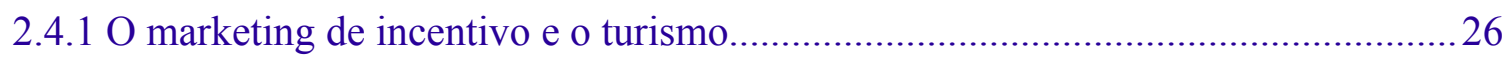

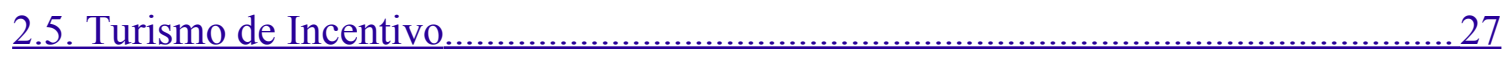

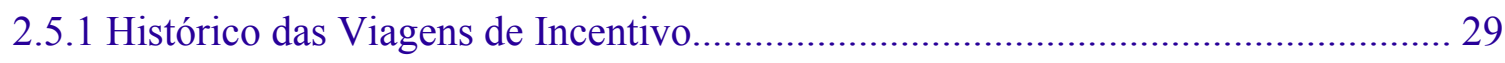

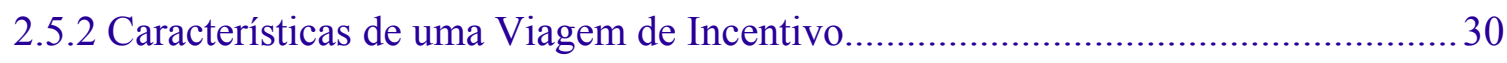

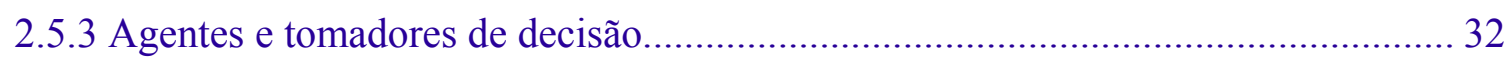

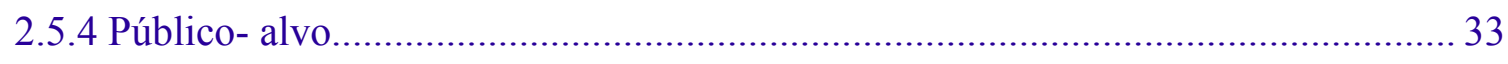

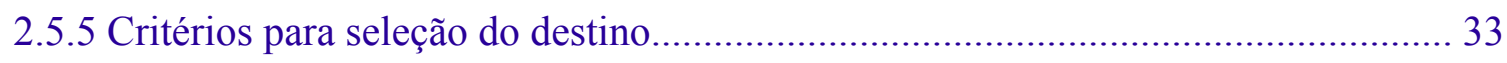

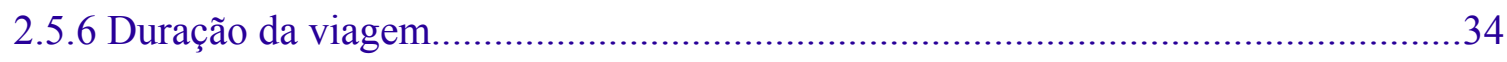

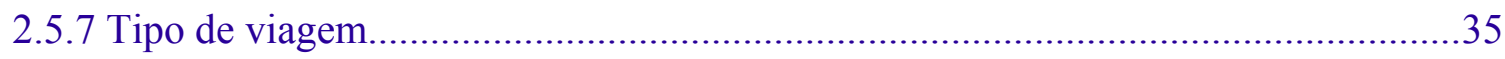

2.5.8 Período de realização das atividades de incentivo................................................. 35

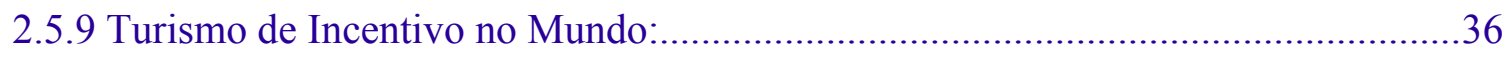

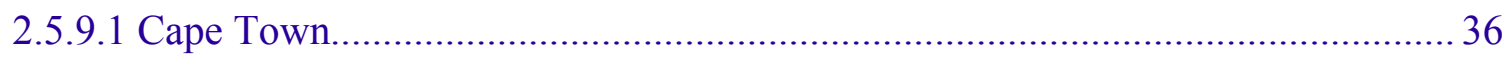

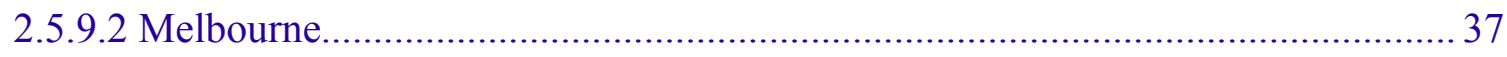

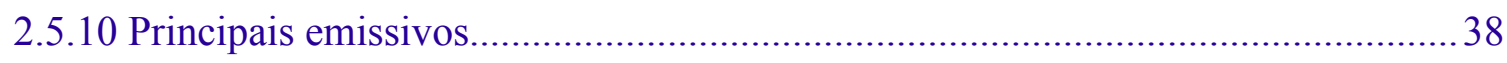

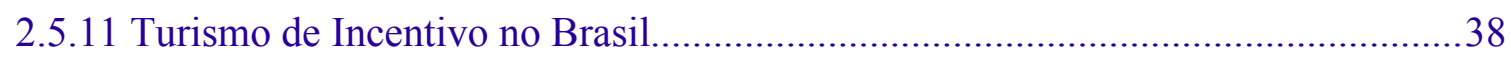

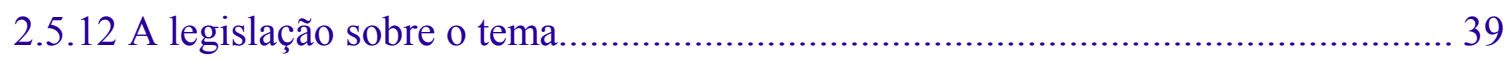

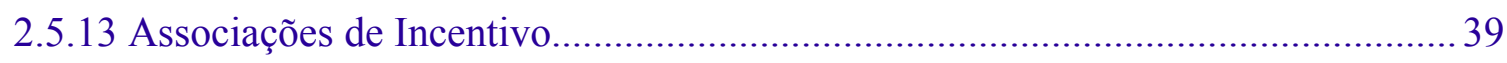

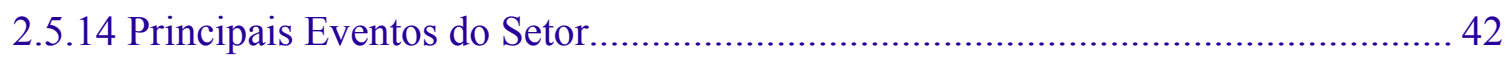


3. MÉTODOS E TÉCNICAS DE PESQUISA ……………………………………….... 44

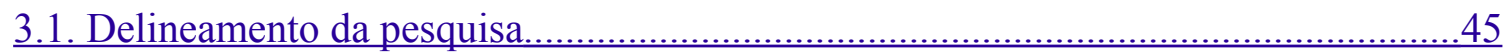

3.2. Caracterização da organização, setor ou área...…………………………………. 45

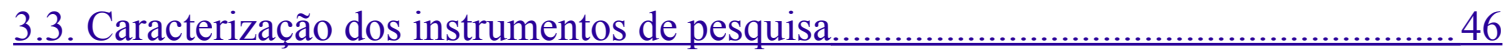

3.4. Procedimentos de coleta e de análise de dados............................................................47

4. APRESENTAÇÃO E ANÁLISE DOS DADOS DA PESQUISA……………………...48

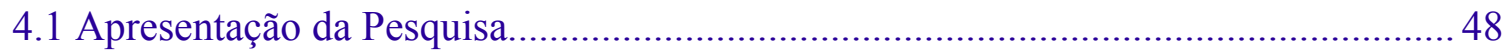

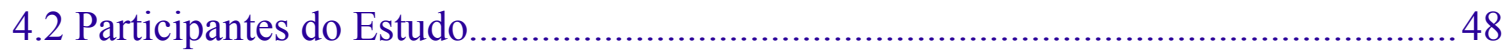

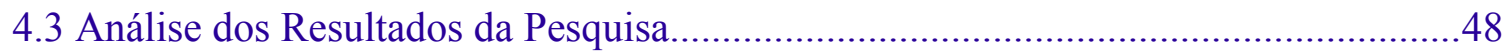

4.3.1 Viagens de Incentivo x Viagens Convencionais.....................................................49

4.3.2 Quanto custa uma viagem de Incentivo................................................................. 50

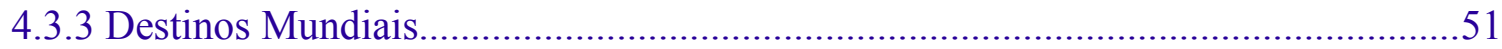

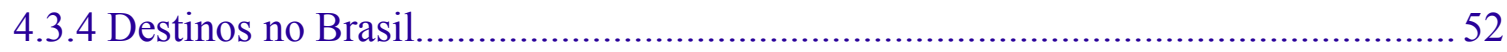

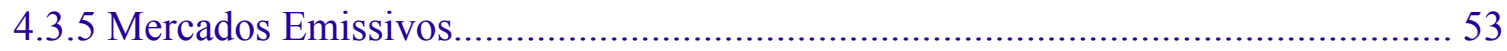

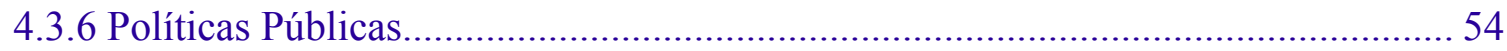

4.3.7 Vocação Brasileira para o Segmento.................................................................... 54

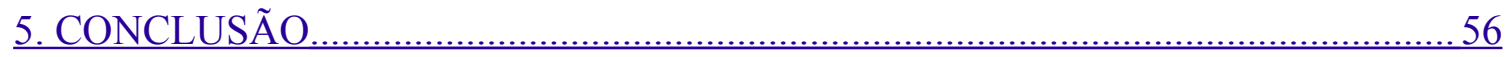

6. CONSIDERAÇÕES FINAIS...………………………………………………... 57

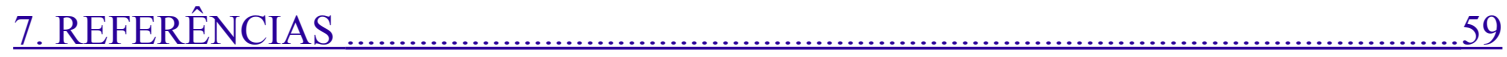

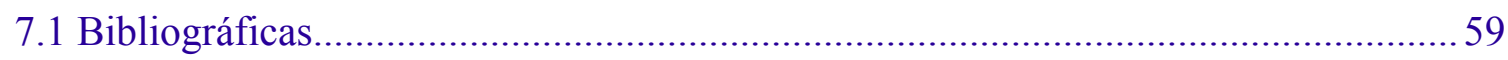

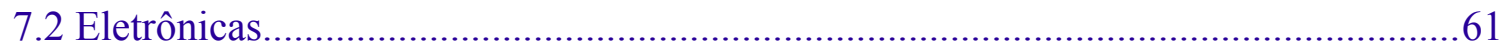

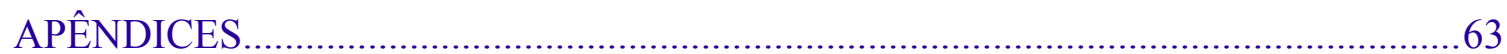

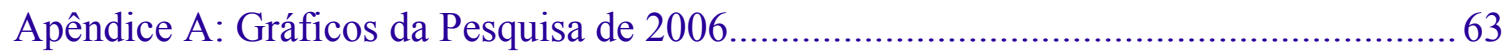

Apêndice B: Roteiro de entrevista com órgãos públicos e associativos................................69

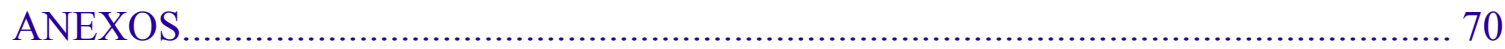

Anexo A: Apresentação AMPRO do dia 19/05/2009......................................................... 70

Anexo B: Fotos com representantes da AMPRO no dia 19/05/2009 ................................. 80

Anexo C: Lista das Principais Feiras de Turismo de Incentivo.............................................. 81 
LISTA DE ILUSTRAÇÕES

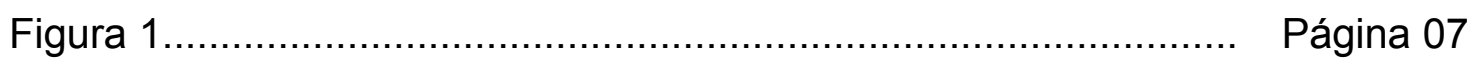

Figura 2 ............................................................... Página 50

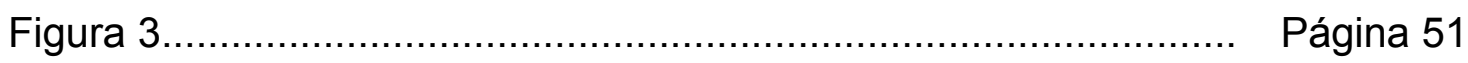

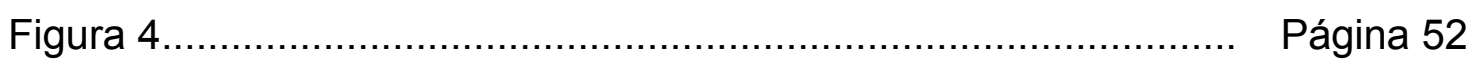




\section{LISTA DE TABELAS}

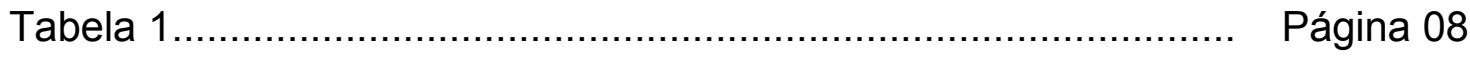

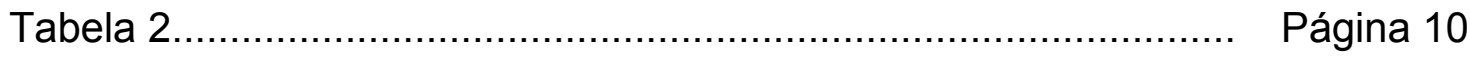

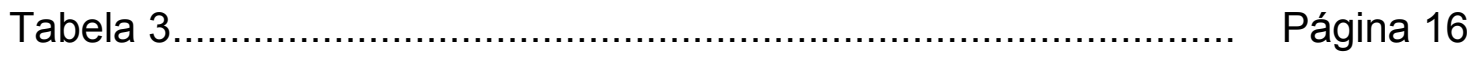

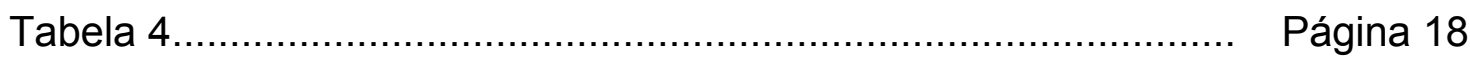




\section{INTRODUÇÃO}

O mundo cada vez mais globalizado e competitivo exige dos profissionais melhores desempenhos. Para alcançá-los, as empresas têm investido em treinamentos a fim de desenvolver profissionalmente e pessoalmente os membros de sua equipe, tornando-os assim colaboradores motivados, motivadores e mais comprometidos com o seu trabalho.

Uma das formas de motivação é via turismo, que nada mais é do que uma premiação em viagens dada pelas empresas como estímulo e recompensa pelo desempenho e produtividade de funcionários e parceiros, ao que se denomina Turismo de Incentivo.

Assim, a presente pesquisa pretendeu fazer um relato sobre o panorama do mercado de Turismo de Incentivo no Brasil, apresentando a importância dessas viagens para o crescimento do turismo nacional sob o ponto de vista publico e privado.

Para tanto, realizou-se um levantamento do histórico do Turismo de Incentivo, bem como suas principais definições e características.

Utilizou-se pesquisa bibliográfica sobre o tema, por meio de um estudo sistemático em livros, revistas, artigos, internet, documentos internos do Ministério do Turismo e do Embratur e outras fontes acessíveis ao público em geral. Foram também elaboradas entrevistas com alguns agentes do segmento de incentivo no país, com intuito de levantar sugestões sobre qual imagem o Brasil poderia adotar para se tornar um destino de Turismo de Incentivo.

\subsection{Contextualização do Assunto / Apresentação e delimitação do tema}

Esta pesquisa tem como objeto principal a análise do Turismo de Incentivo brasileiro, segmento que vem sendo enfocado desde o primeiro Plano de Marketing ${ }^{1}$

${ }^{1}$ Plano Aquarela 2003 -2007, disponível em www.brasilnetwork.tur.br 
do Embratur, em 2003 e trabalhado por agentes da cadeia produtiva do turismo brasileiro desde 1976. Ademais, segundo a ABGEV - Associação Brasileira de Gestores de Viagens Coorporativas (apud TASSITANI, 2008), esse segmento movimenta no mundo cerca de $\mathrm{R} \$ 30,9$ bilhões ao ano. Mesmo assim, de modo geral, é pouco trabalhado pelo trade turístico ${ }^{2}$ brasileiro, que prefere atuar mais efetivamente com turismo emissivo que receptivo.

A importância desse nicho mercadológico ainda não é entendida, conseqüentemente, não se consegue identificar o Brasil como um possível destino de viagens de incentivo.

Em virtude do exposto, este trabalho pretendeu traçar um panorama do Brasil como destino de incentivo e, levando em consideração a opinião do trade e dos órgão públicos responsáveis pelo turismo brasileiro, levantar hipóteses sobre qual seria a vocação do Brasil no segmento de incentivos.

\subsection{Descrição da situação problemática / Formulação do problema}

Diante do vulto dessa movimentação, pode-se afirmar que o mercado de viagens de incentivo está em franca expansão, e esse segmento ainda é pouco desenvolvido por empresários brasileiros.

Neste contexto, surge a seguinte a pergunta de qual seria a vocação do Brasil como destino de incentivos, visto as tendências mundiais para o segmento.

\subsection{Objetivo Geral}

Analisar o Brasil como destino de viagens de incentivo.

\subsection{Objetivos Específicos}

$\checkmark$ Analisar o atual panorama do Turismo de Incentivo no Brasil

${ }^{2}$ Entende-se por trade turístico os meios de hospedagem, bares e restaurantes, centros de conveções e feiras de negócios, agências de viagens e turismo, empresas de transporte, lojas de suvenir's e toda as atividades comerciais periféricas ligadas direta ou indiretamente a atividade turística. 
$\checkmark$ Avaliar as tendências mundiais

$\checkmark$ Verificar a visão do trade turístico

$\checkmark$ Identificar oportunidades e desafios

$\checkmark$ Propor ações

\subsection{Justificativa}

As viagens de incentivo são muito eficientes na hora de se motivar e reconhecer colaboradores e parceiros, pois proporcionam maior valor residual, podendo ficar na memória de cada pessoa por até 10 anos. (GOLRH, 2003)

A Organização Mundial de Turismo - OMT (2001) estima que até 2020 movimentarse-ão cerca de 1,6 bilhão viajantes e os segmentos que tendem a ter maior crescimento no período são eventos, incentivo e aventura.

Os dados acima evidenciam a importância do segmento para o Brasil, que aqui vem se estruturando há 33 anos, e ainda tem muito que avançar.

\subsection{Métodos e Técnicas de Pesquisa}

Procedeu-se de pesquisa bibliográfica, que proporcionou embasamento teórico acerca de turismo, motivação, segmentação, marketing de incentivo e turismo de incentivo. A pesquisa documental, principalmente em documentos internos do Embratur e Ministério do Turismo, propiciou a formatação do atual e anterior cenário do segmento conforme visualizado pela área pública.

Ressalta-se a dificuldade encontrada em conseguir embasamento quanto à área acadêmica sobre o tema ainda pouco estudado e abordado.

Foram efetivadas também entrevistas com o trade turístico brasileiro, que serviram para subsidiar e enriquecer este trabalho. Esse tipo de coleta de dados tem caráter qualitativo, e escolheu-se esta metodologia por se entender que as entrevistas 
podem trazer como resultado, de forma mais detalhada, a percepção de cada entrevistado acerca do assunto. Ademais, foi avaliada a opinião dos agentes do segmento frente ao produto "Brasil como destino de incentivo."

\subsection{Estrutura e Organização do Trabalho}

O presente trabalho inicia-se com a contextualização do tema, no qual foram destacam-se sucintamente os conceitos de turismo, motivação, segmentação e como esses assuntos estão inter-relacionados com o Turismo de Incentivo.

Em seguida, discorre-se acerca de Marketing de Incentivos, a fim de ambientar o leitor ao próximo tema: Viagens de Incentivo. Nesse item, busca-se evidenciar a importância do segmento para um destino apresentado um breve histórico dessa atividade, suas características e o panorama do Turismo de Incentivo no Brasil.

Analisa-se também, as estratégias usadas por alguns destinos de incentivo como as de Cape Town (África do Sul) e Melbourne (Austrália).

Abordam-se também os aspectos metodológicos utilizados justificando o tipo de pesquisa e instrumentos aplicados.

Apresentam-se os dados da pesquisa, mostrando a cada tópico o que a literatura diz acerca do tema bem como a opinião dos entrevistados.

Nas considerações finais desta pesquisa, reflete-se sobre a sua problemática, seus objetivos propostos e seus atingimentos. E por fim, sugeriram-se futuras ações para a otimização do segmento de incentivos no Brasil. 


\section{REFERENCIAL TEÓRICO}

\subsection{Turismo}

As pessoas se movimentam pelos mais distintos motivos e para os mais variados lugares. No entanto, o estudo dessa motivação se iniciou só após a Segunda Guerra Mundial, quando o movimento turístico começou a ganhar força econômica e se estruturar em suas dimensões atuais. A industrialização propiciou o aumento do tempo livre dos empregados que já não passavam mais tantas horas no trabalho, restando-Ihes assim tempo para o lazer e, conseqüentemente, para viagens.

Segundo Wahab (1991, p.23), o primeiro conceito da palavra turismo foi dado, possivelmente, pelo economista austríaco Herman Von Schullard em 1910, sendo

\footnotetext{
"a soma das operações, principalmente de natureza econômica, que estão diretamente relacionadas com a entrada, permanência e deslocamento de estrangeiros para dentro e para fora de um país, cidade ou região." (apud WAHAB, 1991, p.23)
}

Essa definição histórica é focada em um ponto de vista econômico e as várias operações que caracterizam o turismo especialmente de estrangeiros.

Sob outro enfoque, o conceito da Organização Mundial do Turismo (OMT) valoriza o tempo de duração, o local e, principalmente, as motivações que levam a pessoas a se deslocarem:

"As atividades que as pessoas realizam durante suas viagens e estadas em lugares diferentes do seu entorno habitual, por um período inferior a um ano, com finalidade de lazer, negócios ou outras." (Cunha, 1997, p.7).

Já Jafari (1989) explicita os impactos gerados pela atividade turística e também enfatiza a realização da atividade fora de seu ambiente habitual de residência do viajante. Em suas palavras, turismo é

\footnotetext{
"o estudo do homem longe de seu local de residência, da indústria que satisfaz suas necessidades, e dos impactos que ambos, ele e a indústria, geram sobre os ambientes físico, econômico e sociocultural da área receptora" (apud BENI, 2002, p.36)
} 
Hunziker e Krapf (1942; apud BENI, 2002, p.36) também valorizam esta troca que ocorre entre visitantes e visitados, e defendem uma visão não associada aos fatores econômicos. De acordo com os autores é "a soma dos fenômenos e das relações resultantes da viagem e da permanência de não residentes, na medida em, que não leva à residência permanente e não está relacionada a nenhuma atividade remuneratória".

Outra abrangente definição é a de MÖESCH (2004, p.35) que diz que turismo:

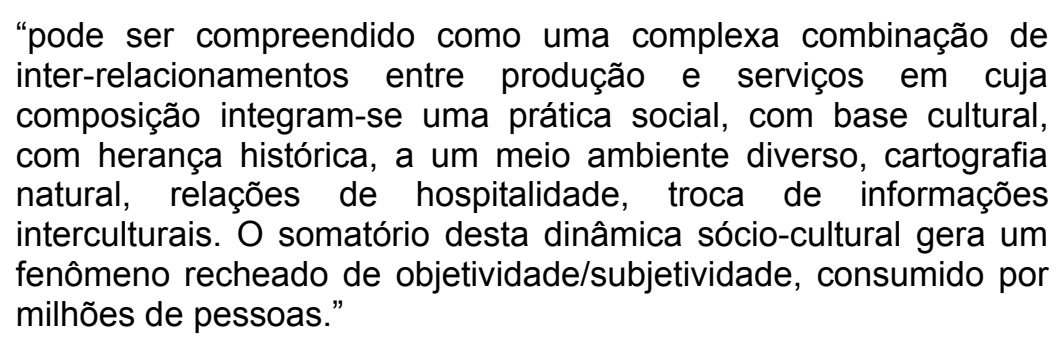

Por se tratar de um conceito com enfoque nas relações sociais, melhor se adequando aos programas de incentivo, a definição de Möesch foi a utilizada neste trabalho. Entretanto fica evidente que há uma visível ampliação no conceito de Turismo, ampliação esta que está diretamente ligada às especificidades da atividade turística.

No item seguinte aborda-se a motivação que leva as pessoas a se deslocarem de seus domicílios para outros locais. 


\subsection{Motivação do Turista}

Saber as razões das diferenças individuais que evidenciam as preferências e os interesses de cada pessoa é tema constante da produção acadêmica. Para Godim e Silva (2004) os psicólogos acreditam que grande parte das razões da diversidade das condutas individuais decorre de um processo chamado Motivação.

Neste sentido, de acordo com a teoria comportamental de Maslow (apud VAZ, 1999; p.42), a motivação se dá em vários níveis, identificados a partir de uma escala das necessidades de cada indivíduo, hierarquizadas de baixo para cima em uma pirâmide. A ânsia e motivação para o lazer, por exemplo, encontra-se no topo dessa pirâmide, conforme ilustra a figura abaixo, inserida nas necessidades de autorealização, de auto-estima e de aceitação social. Essas necessidades só são priorizadas após o suprimento das necessidades fisiológicas e de integridade física. Essa pirâmide pode ser analisada abaixo:

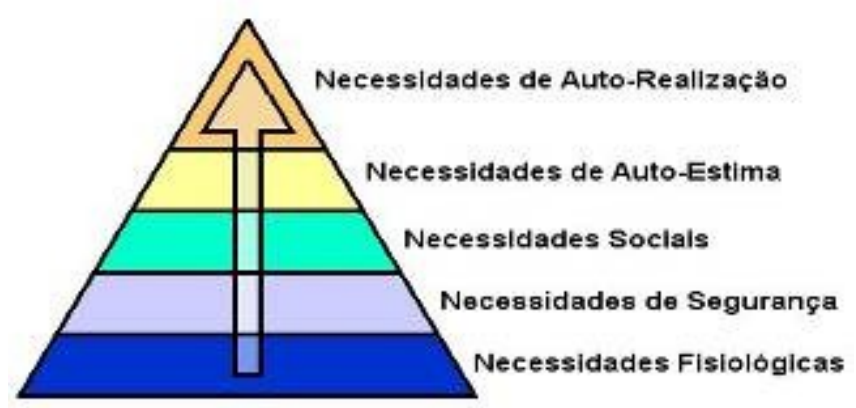

Figura 1: Pirâmide de Maslow FONTE: Portal COSMOCRONOS.

Essa teoria evidencia que, para poder dispor do lazer, o indivíduo deve, primeiramente, sentir-se bem e seguro fisicamente, ou seja, ter suprido sua fome, sede, cansaço, insegurança e só então procura algo que the dê prazer. Assim, Maslow (1954) considera que todas as necessidades motivam e provocam satisfação.

Outros autores como Herzberg (1975) discordam de Maslow acreditando que não são todas as necessidades que motivam, pois algumas apenas evitam a nãosatisfação.

"o oposto de satisfação não é insatisfação, mas sim nenhuma satisfação no trabalho; e, da mesma forma, o oposto de insatisfação no trabalho não é satisfação, mas sim nenhuma insatisfação no trabalho" (Herzberg, 1975, p.07) 
Portanto, para Herzberg (1975), a motivação só ocorre quando a satisfação se dá na realização do individuo e não no simples suprimento de suas necessidades. E entenda-se como necessidades aquelas de sobrevivência e também as condições de trabalho. Para realmente se motivar, são necessárias recompensas externas como por exemplo no caso de colaboradores de uma empresa, em que essas recompensas seriam os programas de incentivos e as internas, o reconhecimento profissional.

No turismo para se compreender melhor o que o indivíduo busca ao praticar essa atividade, isto é o que o leva a viajar, é preciso explicitar suas motivações.

A Organização das Nações Unidas ONU (1979) apresenta uma classificação para as motivações das viagens:

\begin{tabular}{|l|}
\hline $\begin{array}{l}\text { Classificação do motivo da visita (ou viagem) por divisões, para turismo receptor, } \\
\text { emissor e interno }\end{array}$ \\
\hline Lazer, recreação e férias \\
\hline Visitas a parentes e amigos \\
\hline Negócios e motivos profissionais \\
\hline Tratamento de Saúde \\
\hline Religião / Peregrinações \\
\hline Outros Motivos \\
\hline
\end{tabular}

Tabela 1: Classificação do motivo da visita (ou viagem) por divisões, para turismo receptor, emissor e interno. Fonte: ONU (apud Dias, 2002, p.29)

De acordo com a tabela, pode-se afirmar que as viagens de incentivo inserem-se em negócios e motivos profissionais, uma vez que é a empresa que escolhe o destino e o roteiro da viagem.

Ross (2002, p. 28) utiliza a relação entre lazer e trabalho para esclarecer as motivações dos turistas, uma vez que são extremamente importantes. Ele menciona o efeito "contaminação", em que a natureza do trabalho influencia diretamente na escolha da pessoa em relação à atividades de turismo. Essa teoria supõe que as 
atitudes e hábitos adquiridos no trabalho são transferidos para o comportamento escolhido pelo turista, o que explicaria as escolhas de destinos e formato de viagens de grupos de incentivo, pois uma vez que possuem hábitos em comum, este grupo teria comportamento similar como turista.

A contaminação trabalho versus lazer pode ser positiva quando uma característica profissional desejável para o trabalhador pode ser encontrada na atividade de lazer escolhida ou pode ainda ser negativa quando um aspecto indesejável do trabalho se introduz nas atividades de lazer. No caso de viagens de incentivo, os roteiros devem procurar exaltar as qualidades desejáveis nesses funcionários, como pró-atividade, dinamismo, etc., e explorá-las de forma lúdica. Da mesma maneira, atividades relacionadas ao dia-a-dia da empresa devem ser evitadas neste tipo de viagem.

Outro postulado citado por Ross é de "tempo livre ou horas de lazer e horas que não estão a sua disposição, nem são usadas no trabalho" (ROSS, 2002, p.28). É mais complexo definir essa hipótese, pois o que pode ser considerado como lazer para algumas pessoas, para outras pode ser encarado como uma limitação às horas de lazer, como é o caso do tempo dedicado à família.

Ele fala, ainda, dos tipos de gratificações procuradas pelo trabalhador.

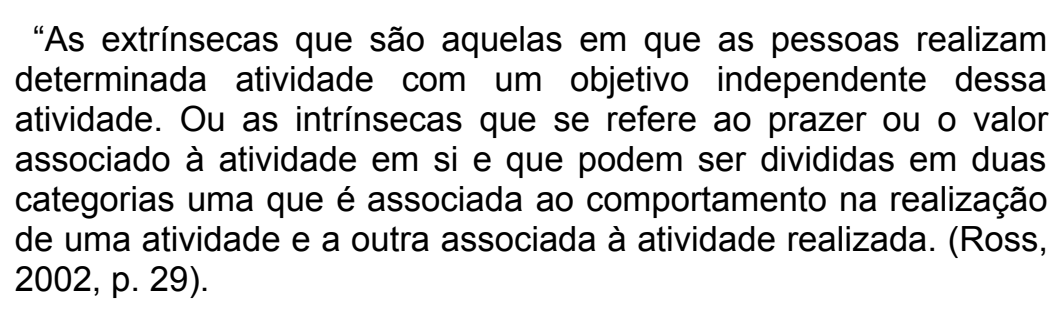

Nesse caso, o Turismo de Incentivo estaria associado às gratificações extrínsecas, pois, ao cumprirem metas, estão almejando a premiação.

A seguir, um diagrama que ilustra esse modelo, adaptado de Ross (2002, p. 29): 


\begin{tabular}{|l|l|l|}
\cline { 2 - 3 } \multicolumn{1}{c|}{} & \multicolumn{2}{l|}{ Tipo de voluntarismo } \\
\hline $\begin{array}{l}\text { Tipo de } \\
\text { Gratificação }\end{array}$ & Compulsório & Voluntário \\
\hline Intrínseco & Trabalho Divertido (Célula 1) & Turismo (Célula 3) \\
\hline Extrínseco & Trabalho (Célula 2) & Turismo Obrigatório (Célula 4) (Célula 4) \\
\hline
\end{tabular}

Tabela 2: Tipologia turismo/trabalho adaptada da tipologia lazer/trabalho. (Adaptado de Banner e Himmelfarb, 1985.)

- Célula 1: compreende os indivíduos que trabalham em empregos intrinsecamente interessantes. Esse tipo de trabalho pode ser definido como interessante e percebido como necessário pela mesma razão psicológica.

- Célula 2: conceito-padrão de trabalho para muitas pessoas, aquele percebido como necessário, realizado só por dinheiro, por exemplo, e oferece poucas ou nenhuma experiência psicológica positiva.

- Célula 3: o autor chama de "turismo puro". Compreende aqueles que optam por atividades de turismo devido ao seu valor intrínseco e prazer potencial.

- Célula 4: compreende atividade não-profissionais que se encaixam entre o trabaIho e o turismo voluntário. Poderia abranger atividades que não são consideradas nem de trabalho nem de turismo. Exemplo: visita a familiares ou obrigações sociais ou cívicas. Cabe aqui também o turismo realizado por razões de status.

Ross (2002, p. 30) não vê, portanto, trabalho e turismo como uma dicotomia, mas como duas tipologias em extremidades opostas conexas. Na extremidade do turista, há aquelas atividades em que são vistas como uma questão de escolha e na outra extremidade, a do trabalho, são atividades em que são vistas como uma questão compulsória. Dessa forma, é possível considerar mais de uma concepção de trabalho e também de turismo.

Já outros autores se baseiam a partir do turismo moderno para explicar as motivações dos turistas. Para eles, elas são as causas subjetivas que vão fazer com que o individuo escolha sua viagem. De acordo com Arrillaga (1976 apud Barretto, 1999, p.64-65), as motivações vão desde o desejo de viajar por viajar até a busca da 
felicidade, passando pelo desejo de fazer coisas que implicam uma viagem e desejo de viver novas experiências para quebrar a monotonia.

No princípio da humanidade a decisão de viajar não era tomada por livre e espontânea vontade, mas sim por necessidade de sobrevivência. Por isso na préhistória predomina a fase nômade, quando nossos ancestrais percorriam o mundo à procura de alimentos e proteção.

Gil Nuno Vaz (1999; p.42) aponta que nos dias atuais as fontes motivadoras que determinam a escolha de uma viagem são os seguintes fatores:

-Pessoal: pelo qual o motivo é a própria pessoa, seja por questões individuais ou psicológicas;

-Familiar: o indivíduo é influenciado por parentes;

-Social: a influência é dada pela opinião do grupo em que a pessoa está inserida, como sindicatos, grupos de apoio, etc.;

- Organizacional: a viagem é determinada pela empresa em relação a um determinado profissional, geralmente viagens de negócios ou de incentivo.

De acordo com o grau de escolha pode-se classificar desde a livre escolha, quando nenhum fator condicionante exterior ao indivíduo ocorre; até a completa contingência que uma obrigatoriedade impõe, passando por diversas etapas intermediárias de opções negociadas.

Mas afinal, o que leva as pessoas a escolherem o turismo como forma de aproveitar o tempo ocioso?

A mudança de ambiente, com certeza, é o principal motivo.

"O desejo de viajar, de deixar o local de vida cotidiana, a vontade de sentir o cheiro de outras localidades, de ver o sol nascer e se pôr com nuanças diversas daquelas que são o dia-a-dia do ser, cidadão. Esta necessidade sustenta e sustentará sempre a indústria do Turismo." (PIRES, 1983, p. 36) 
Nesse sentido, fica evidente a necessidade de se deslocar, de sair da rotina e do local onde ela ocorre.

A busca pelo repouso é outro forte fator, especialmente no mundo atual cheio de estresse e rotina que podem ser minimizados pela recreação e tratamentos, conforme evidencia a citação:

\begin{abstract}
"O embrião da atividade turística encontra-se nas causas das primeiras migrações humanas, manifestadas através de um impulso que impelia os primatas a mudarem de local, a encontrarem um refugio seguro, uma proteção contra os predadores. Novos perigos, entretanto, exigiam outra mudança, que muitas vezes acarretava longas peregrinações. O turismo pode ser explicado, assim, como uma solução ritualizada para conciliar os dois impulsos, o sedentário que procura preservar o animal dos riscos inerentes aos ambientes desconhecidos, e o migratório, que propulsiona o animal a explorar novas paragens. Se o homem moderno viaja a negócios, por prazer, ou em busca de conhecimentos, as raízes dessa atividade ainda permanecem ligadas àquela necessidade ancestral de mudança, de descortinar novos horizontes e, com isso, amenizar problemas originados da civilização: o ambiente tenso das grandes cidades, a falta de momentos descompromissados." (LEITE, 1991)
\end{abstract}

Assim, devido à necessidade de mudanças na vida cotidiana e cada vez mais estressante dos indivíduos, o turismo surge como uma alternativa para amenizar esses impactos .

O turismo também pode ser uma ferramenta para a projeção social. Muitas pessoas buscam afirmação social com viagens a lugares que são em suas concepções sinônimo de status como, por exemplo, SPAs, resorts, determinados destinos europeus (ex: Paris, Milão), etc.

Praticidade, funcionalidade e economia também fazem a diferença na hora de escolher uma destinação.

Diante de tantas motivações emerge a necessidade de personalizar o produto turístico para cada cliente, a fim de atender esses anseios de maneira que se consiga atingir um patamar mais elevado da satisfação do cliente em relação ao serviço oferecido. 
No item seguinte são abordadas as diferentes maneiras de motivação dos turistas em relação à segmentação do turismo.

\subsection{Segmentação do Turismo}

O turismo sofre inovações constantes em face à elevada competitividade dos mercados e das expectativas da demanda.

Nos últimos anos o turista passou não só a ser mais exigente e lutar pelos seus direitos, mas também a direcionar suas reivindicações para outras espécies de produtos. Frente a isso se destaca a função do marketing de serviços que extrapola as barreiras de satisfazer o cliente visando agora o seu encantamento.

O conhecimento das características e motivações dos consumidores permite o desenvolvimento dos produtos e serviços focados nos indivíduos e também a melhor forma de atendimento, de venda e de conhecimento das condições de consumo. A atividade turística também apresenta uma tendência à especialização, visto que as empresas do setor passam a oferecer produtos destinados a clientelas específicas. Com essa atitude essas empresas buscam diminuir seus prejuízos com anúncios publicitários e programas de fidelização a clientes que não estariam interessados no produto. A essa especialização do mercado, ou seja, a essa organização mercadológica em função dos consumidores, dá-se o nome de segmentação, pois de acordo com Pinto:

\footnotetext{
"Afinal, mercados são pessoas, pessoas são indivíduos, e os indivíduos são individuais nas suas preferências, nas suas necessidades, nos seus gostos, nas suas idiossincrasias. E a busca desses objetivos homogêneos de consumidores, num certo sentido, talvez, seja o objetivo, por excelência, da atividade de marketing". (PINTO, 1980, apud COBRA, 1997, p 72).
}

Neste sentido, deve-se enfatizar que, ao se segmentar a clientela, opta-se voluntariamente por concentrar seus esforços de marketing em determinados segmentos do mercado, possivelmente abandonando os outros segmentos, mesmo que esses se constituam um potencial. 
De acordo com Beni a segmentação é a melhor maneira de se estudar o mercado turístico:

\begin{abstract}
"É a técnica estatística que permite decompor a população em grupos de igual gênero e natureza, e também a política de marketing que divide o mercado em partes homogêneas, cada uma com seus próprios canais de distribuição, motivações diferentes e outros fatores. Com essa segmentação é possível o conhecimento dos principais destinos geográficos e tipo de transporte, da composição demográfica dos turistas, como faixa etária e ciclo de vida, nível econômico ou de renda, incluindo a elasticidade-preço da oferta e da demanda e da sua situação social, como escolaridade, ocupação, estado civil e estilo de vida". (BENI, 2002, p.153)
\end{abstract}

Ele também afirma que a segmentação traz enormes vantagens como economia de escala para empresas turísticas, aumento da concorrência no mercado, criação de política de preço e de propaganda especializada e promoção de um número maior de pesquisas científicas.

Segundo o jornal O Estado de São Paulo:

“(...) desenvolver produtos e serviços para públicos segmentados pode ser garantia de sucesso para empresários que saibam como atender precisamente as necessidades de seus possíveis clientes. O risco, no entanto, está em investir sem conhecer o que o consumidor quer comprar" (apud ANSARAH, 1999, p.192)

Tal afirmativa evidencia que uma segmentação mal planejada pode ser o fracasso de uma empresa. Algumas empresas, inclusive do setor turístico, que se especializam em determinado destino focando em um público específico, e com as mudanças de tendências ou simplesmente por fatores externos, se vêem arruinadas.

Como exemplo, pode-se citar o caso das praias do sul do Brasil que por anos tiveram suas economias atreladas aos turistas argentinos. Com a recessão na Argentina e a conseqüente queda do fluxo de turistas, algumas cidades passaram por graves problemas econômicos.

Outra desvantagem em segmentar os produtos turísticos é que o público fica acostumado a vincular uma determinada imagem a um empreendimento e muitas vezes não consegue compreender uma possível mudança de mercado. Como 
exemplo disso pode-se citar o caso da operadora de viagens Stella Barros que se especializou no destino Disney durante anos, tendo um rápido crescimento de clientes e de fama. Entretanto, com a alta do dólar em 1999 e o conseqüente declínio das viagens ao exterior, a empresa viu-se obrigada a mudar sua imagem e investir em novos produtos. Mas sua marca já estava consolidada e o público não conseguiu compreender essa mudança levando-a a sérios problemas financeiros.

A especialização de mercado emergiu a partir das últimas décadas do conceito central de pesquisa de consumo e, por essa razão, a segmentação é freqüentemente definida como uma técnica de pesquisa que busca identificar pessoas que tenham comportamentos razoavelmente homogêneos para os efeitos das compras, o que contribui muitas vezes para a descoberta e exploração de novas oportunidades mercadológicas.

Essa segmentação deve ser feita dentro dos seguintes propósitos: identificar consumidores atuais e potenciais para que se explicite quem faz parte de seu mercado alvo; quantificar a demanda potencial e efetiva a fim de que se tenha dados claros a respeito desse mercado; direcionar ações de marketing formatando o produto de acordo com as necessidades e expectativas do mercado, escolhendo os meios de comunicação em que será feita sua publicidade, etc.; e enfim avaliar a viabilidade financeira dessas ações, isto é, se o retorno será satisfatório de acordo com os objetivos propostos pela segmentação.

Cláudia Correa de Almeida Moraes diz que há duas estratégias de segmentação:

“(...) o marketing diferenciado, em que os esforços serão direcionados de maneira diferente para os diversos segmentos da empresa podendo levar ao crescimento no volume de vendas, a obtenção de maior rentabilidade e ao bom posicionamento em cada um dos segmentos, mas os custos para atuar em varias frentes poderão não compensar a segmentação e o marketing concentrado no qual os esforços serão destinados a um único segmento e com isso a empresa pode obter um posicionamento mais sólido, pois ao encontrar o nicho certo de seu produto, a empresa pode oferecer proximidade maior com o consumidor, bens e serviços competitivos alem de estabelecer pontos de venda mais adequados e utilizar veículos de publicidade selecionados exclusivamente ao segmento visado". (MORAES, apud ANSARAH, 1999, p. 16) 
Assim, a citada autora defende que o marketing concentrado seria a maneira mais eficaz de atuação das empresas que focariam em apenas um grupo de consumidor.

Outras modalidades de segmentação podem ser encontradas nas tabelas a seguir:

\begin{tabular}{|l|l|}
\hline Modalidades & Critérios \\
\hline Geográfica & $\begin{array}{l}\text { Extensão do mercado, potencial, concentração geográfica, transporte } \\
\text { e acesso, polarização, bairros e ruas, trafego, centro de compras. }\end{array}$ \\
\hline Demográfica & Idade, sexo, domicilio, família e ciclo de vida. \\
\hline Socioeconômica & $\begin{array}{l}\text { Classe de renda, instrução, ocupação, status, migração, mobilidade } \\
\text { social. }\end{array}$ \\
\hline Padrões de Consumo & $\begin{array}{l}\text { Freqüência de compra, local de compra, lealdade a marcas, heavy } \\
\text { ight user, curva ABC. }\end{array}$ \\
\hline Benefícios procurados & $\begin{array}{l}\text { Satisfação sensorial, prestigio social, emulação-preço favorável, } \\
\text { qualidade| durabilidade, redução de custos, atendimento e serviços }\end{array}$ \\
\hline Estilo de Vida & $\begin{array}{l}\text { Expectativa de vida, uso do tempo, interesses predominantes, } \\
\text { participação em eventos e agrupamentos sociais, uso do dinheiro, } \\
\text { amizades e relações pessoais. }\end{array}$ \\
\hline Personalidade & $\begin{array}{l}\text { Bases culturais, atitudes e valores, liderança } \\
\text { acessibilidade, uso e aplicações, unidade de decisão de compra, } \\
\text { demanda derivada. }\end{array}$ \\
\hline
\end{tabular}

Tabela 3: Modalidades de Segmentação

Fonte: PIMENTA E RICHERS (apud ANSARAH, 1999, pág. 18.)

Outro enfoque que se segue é apresentado por Ignarra (1998):

\begin{tabular}{|l|l|}
\hline Critérios de segmentos & Segmentos \\
\hline \multirow{4}{*}{ Idade } & Turismo infantil \\
\cline { 2 - 2 } & Turismo juvenil \\
\cline { 2 - 2 } & Turismo meia idade \\
\cline { 2 - 2 } & Turismo familiar \\
\hline
\end{tabular}




\begin{tabular}{|c|c|}
\hline \multirow[t]{3}{*}{ Nível de renda } & Turismo social \\
\hline & Turismo de maioria \\
\hline & Turismo de minoria \\
\hline \multirow[t]{4}{*}{ Meios de transportes } & Turismo aéreo \\
\hline & Turismo fluvial/lacustre \\
\hline & Turismo rodoviário \\
\hline & Turismo marítimo \\
\hline \multirow[t]{3}{*}{ Duração e permanência } & Turismo de curta duração \\
\hline & Turismo de média duração \\
\hline & Turismo de longa duração \\
\hline \multirow[t]{5}{*}{ Distancia do mercado consumidor } & Turismo local \\
\hline & Turismo regional \\
\hline & Turismo nacional \\
\hline & Turismo continental \\
\hline & Turismo intercontinental \\
\hline \multirow[t]{5}{*}{ Tipos de grupos } & Turismo individuais \\
\hline & Turismo de casais \\
\hline & Turismo de famílias \\
\hline & Turismo de grupos \\
\hline & $\begin{array}{l}\text { Turismo para grupos especiais (single, terceira } \\
\text { idade, GLS...) }\end{array}$ \\
\hline \multirow[t]{2}{*}{ Sentido do fluxo turístico } & Turismo emissivo \\
\hline & Turismo receptivo \\
\hline \multirow[t]{4}{*}{ Condição geográfica da destinação turística } & Turismo de praia \\
\hline & Turismo de campo \\
\hline & Turismo de neve \\
\hline & Turismo de montanha \\
\hline
\end{tabular}




\begin{tabular}{|c|c|}
\hline \multirow[t]{6}{*}{ Aspecto cultural } & Turismo étnico \\
\hline & Turismo religioso \\
\hline & Turismo histórico \\
\hline & Turismo antropológico \\
\hline & Turismo artístico \\
\hline & Turismo de acontecimentos programados \\
\hline \multirow[t]{3}{*}{ Grau de urbanização da destinação turística } & Turismo de grandes metrópoles \\
\hline & Turismo de médias cidades \\
\hline & Turismo de pequenas cidades \\
\hline \multirow[t]{13}{*}{ Motivação das viagens } & Turismo rural \\
\hline & Turismo de áreas naturais \\
\hline & Turismo de negócios \\
\hline & Turismo de eventos \\
\hline & Turismo de entretenimento \\
\hline & Turismo de saúde \\
\hline & Turismo educacional \\
\hline & Turismo de aventura \\
\hline & Turismo esportivo \\
\hline & Turismo de pesca \\
\hline & Turismo de descanso \\
\hline & Turismo de natureza \\
\hline & Turismo cultural \\
\hline
\end{tabular}

Tabela 4: Critérios de Segmentação

FONTE: Ignarra (1998;80-81 apud AMARAL, 2005 p. 26)

No âmbito governamental, o Ministério do Turismo brasileiro entende segmentação como:

“... uma forma de organizar o turismo para fins de planejamento, gestão e mercado. Os segmentos turísticos podem ser estabelecidos a partir dos elementos de identidade da oferta e também das características e variáveis da demanda". (BRASIL, 2005, pg. 3). 
Em seus "Marcos Conceituais", o Ministério do Turismo (2005, pg.3), partindo da segmentação da oferta, define tipos de turismo cuja identidade pode ser conferida pela existência de:

1.atividades, práticas e tradições (agropecuária, pesca, esporte, manifestações culturais, manifestações de fé)

2.aspectos e características (geográficas, históricas, arquitetônicas, urbanísticas, sociais)

3.determinados serviços e infra-estrutura (de saúde, de educação, de eventos, de hospedagem, de lazer)

Enfocando a demanda, a segmentação estabelecida pelo Ministério é definida pela identificação de certos grupos de consumidores caracterizados a partir das suas especificidades em relação a alguns fatores que determinam suas decisões, preferências e motivações, ou seja, a partir das características e das variáveis da demanda.

A publicação "Marcos Conceituais" ainda cita:

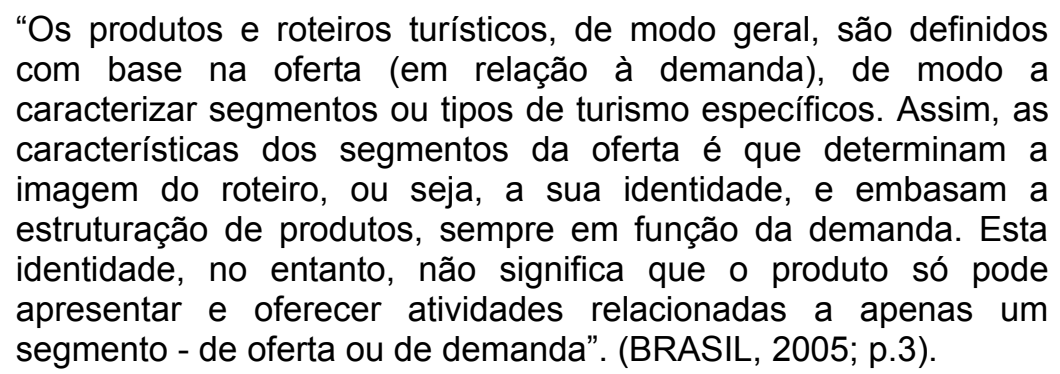

Ao adotar a segmentação como estratégia, o Ministério do Turismo conceituou, os principais segmentos da oferta que são: Ecoturismo, Turismo Cultural, Turismo de Estudos e Intercâmbio, Turismo de Esportes, Turismo de Pesca, Turismo Náutico, Turismo de Aventura, Turismo de Sol e Praia, Turismo de Negócios e Eventos, Turismo Rural e Turismo de Saúde. 
O Ecoturismo abrange turistas que anseiam contato com a natureza de forma consciente, de modo a preservar o meio ambiente. De acordo com os "Marcos Conceituais":

\begin{abstract}
Ecoturismo é um segmento da atividade turística que utiliza, de forma sustentável, o patrimônio natural e cultural e incentiva sua conservação e busca a formação de uma consciência ambientalista através da interpretação do ambiente, promovendo o bem - estar das populações. (BRASIL, 2005; p.9).
\end{abstract}

Neste sentido,o Ecoturismo é visto como um turismo voltado para apreciação de ambientes naturais e culturais enfocando sempre a sustentabilidade.

No Turismo Cultural a principal motivação do turista está relacionada sua vontade em vivenciar o patrimônio histórico e cultural de uma localidade. Este turismo compreende atividades relacionadas à vivência do conjunto de elementos significativos do patrimônio histórico e cultural e dos eventos culturais, valorizando e promovendo os bens materiais e imateriais da cultura. (BRASIL, 2005, p.13).

Apesar do conceito de cultura ser amplo, ao definir Turismo Cultural o Ministério do Turismo foca na experiência do indivíduo com os patrimônios de uma localidade.

O Turismo de Estudos e Intercâmbio é baseado na educação e profissionalização de pessoas, envolvendo a troca de aprendizagem, cultura e conhecimento com os indivíduos do destino. De acordo com o Ministério do Turismo, Turismo de Estudos e Intercâmbio constitui-se na movimentação turística gerada por atividades e programas de aprendizagem e vivências para fins de qualificação, ampliação de conhecimento e de desenvolvimento pessoal e profissional (BRASIL, 2005, p.19).

O Turismo de Esportes surge a partir do ato de viajar por razões esportivas e seus desdobramentos. Este segmento é mais rentável, pois não é somente o atleta que irá competir que vai participar do processo. Há ainda a participação de toda a equipe e daqueles que observam o esporte. É assim descrito:

"Turismo de esportes compreende as atividades turísticas decorrentes da prática, envolvimento ou observação de modalidades esportivas" (BRASIL, 2005; p.23). 
Estão inseridos neste segmento os eventos esportivos como competições, campeonatos ou simples jogos amistosos.

O Turismo de Pesca fundamenta-se nos movimentos turísticos que ocorrem em territórios específicos em relação ao perfil do turista de pesca. Esse perfil é definido pela motivação do turista, a qual determina a evolução da atividade de pesca como opção de lazer, caracterizado pelo usufruto dos recursos naturais de forma sustentável, de acordo com as peculiaridades de ambas as atividades. Compreende "(...) as atividades turísticas decorrentes da prática de pesca amadora." (BRASIL, 2005, p.28).

O Turismo Náutico pode ser caracterizado como Turismo Fluvial, em Represas, Lacustre e Marítimo. Pode envolver atividades como cruzeiros, passeios, excursões e viagens via quaisquer tipos de embarcações náuticas para fins turísticos. Caracteriza-se "(...) pela utilização de embarcações náuticas como finalidade da movimentação turística" (BRASIL ,2005, p.34).

Apesar de possuir características próprias, o Turismo de Aventura pode estar associado ao Ecoturismo, pois algumas das atividades desse segmento devem ser realizadas na natureza e com os mesmos princípios do Ecoturismo. O Turismo de Aventura deve estar comprometido, principalmente, com a segurança pelos riscos que pode oferecer. É direcionado a indivíduos que buscam estilos de vida mais saudáveis e "compreende os movimentos turísticos decorrentes da prática de atividades de aventura de caráter recreativo e não competitivo" (BRASIL, 2005, p.39).

O Turismo de Sol e Praia é um dos mais praticados nos dias atuais. No Brasil, tem sua alta estação durante as férias escolares, uma vez que os pais usufruem do recesso do trabalho juntamente aos filhos, para viajar em direção à costa. Escolhido também por outros grupos da sociedade, "constitui-se das atividades turísticas relacionadas à recreação, entretenimento ou descanso em praias, em função da presença conjunta de água, sol e calor" (BRASIL, 2005, p. 43).

Já o Turismo Rural também possibilita relaxamento, diversão e tem conquistado cada vez mais adeptos, por proporcionar o distanciamento da realidade estressante da rotina. É capaz de permitir o contato com a natureza e com a produção 
agropecuária. Oferece também a possibilidade de um maior descanso pela serenidade da propriedade em se localizar distante dos centros urbanos. Ademais, é atrativo às crianças pela integração com as atividades do campo, sendo "comprometido com a produção agropecuária, agregando valor a produtos e serviços, resgatando e promovendo o patrimônio cultural e natural da comunidade" (BRASIL, 2005, p.49).

O Turismo de Saúde visa à preservação do próprio indivíduo. Fala-se em preservar a cultura e o meio-ambiente, mas, neste caso, o centro dessa preservação é o ser. As pessoas que procuram este segmento não, necessariamente, precisam estar enfermas, basta almejar qualidade de vida. É assim definido: "Turismo de Saúde constitui-se das atividades turísticas decorrentes da utilização de meio e serviços para fins médicos, terapêuticos e estéticos". (BRASIL, 2005, p.53).

O Turismo de Negócios abrange visitas técnicas, reuniões, exposições comerciais, compra e venda de produtos e serviços entre outros do gênero. Já os Eventos compreendem encontros programados e organizados como congressos, convenções, simpósios, lançamentos, mostras, exposições e feiras. É visto como turismo de negócios e eventos:

“(...) o conjunto de atividades turísticas decorrentes dos encontros de interesse profissional, associativo, institucional, de caráter comercial, promocional, técnico, científico e social” (BRASIL 2005, p.46).

O Turismo de Incentivo, objeto de estudo desta pesquisa, está inserido no segmento de Negócios e Eventos, por se tratar, muitas vezes, de viagens que envolvem interesses comerciais, uma vez que essas viagens são premiações oferecidas por empresas a seus colaboradores e parceiros por metas alcançadas em programas pré-estabelecidos de marketing de incentivo.

No item seguinte analisa-se o que é marketing de incentivo, seu funcionamento e como ele funciona como motivador do Turismo de Incentivo. 


\subsection{Marketing de Incentivos}

Para aprofundar-se no entendimento do Turismo de Incentivo, faz-se necessária a compreensão do meio pelo qual este tipo de turismo ocorre, ou seja, o marketing de incentivo é o propiciador das viagens de incentivo.

A globalização e o aumento da competitividade no cenário corporativo nacional e internacional exigiram que as empresas passassem a utilizar estratégias eficazes para a ampliação da produtividade e do faturamento, melhoria de imagem ou de posicionamento, focadas principalmente na motivação dos colaboradores para o alcance de metas propostas. Em épocas de crise, essas ações tornam-se ainda mais necessárias, já que há tendência de redução das receitas das empresas, e para a manutenção de um equilíbrio, as vendas devem ser estimuladas.

Nesse contexto, o marketing de incentivo, oriundo do marketing promocional, surge como um grande aliado, oferecendo um conjunto de ferramentas que auxiliam no processo de motivação dos diferentes públicos-alvo - internos e externos - ao alcance dos diversos objetivos comerciais, mercadológicos e institucionais da empresa, sejam eles quantitativos ou qualitativos. Para tanto, utilizam-se principalmente de competições nas quais os bons resultados originam benefícios, sejam eles financeiros, econômicos ou emocionais. Assim sendo, aos vencedores são oferecidos prêmios valorizados pelo seu grupo, gerando ainda maior distinção.

A AMPRO conceitua marketing de incentivo como sendo:

\footnotetext{
“(..) uma ferramenta utilizada para motivar equipes internas, distribuidores e revendedores a atingirem objetivos e metas, oferecendo premiação e reconhecimento para as melhores performances". (AMPRO)
}

Esta citação evidencia a importância do planejamento no marketing de incentivo, pois ele só será de fato eficaz se houver metas e objetivos.

Normalmente essas metas e objetivos são desenvolvidas com foco em aumento de produtividade, vendas, integração, alavancagem e lançamento de produtos, mudança de cultura, geração de idéias, qualidade, entre outros objetivos. Por meio de programas de incentivo também é possível mudar comportamentos e atitudes, 
despertar e fortalecer o sentimento de orgulho, a coragem e o comprometimento dos participantes.

Historicamente, Silvana Torres evoca os Jogos Olímpicos para identificação das primeiras atividades relacionadas ao marketing de incentivos enfatizando:

\begin{abstract}
"Traçando paralelos entre a história dos jogos Olímpicos e o Marketing de Incentivos, podemos apontar algumas analogias. Assim como o Estado tinha nos jogos Olímpicos uma fonte de preparação dos atletas para combates, as empresas estabelecem programas de incentivos para suas equipes mais do que uma forma de premiar os melhores; tais programas visam treinar, capacitar equipes para um mercado altamente competitivo, que, mais do que nunca, se parece com uma batalha. Dessa forma, treinamento e capacitação estão acima dos prêmios que se acaba distribuindo" (TORRES, 2000,p.8)
\end{abstract}

Torres evidencia o retorno que a empresa terá com colaboradores melhor capacitados e comprometidos com a empresa.

Nos últimos anos, esta atividade de marketing tem crescido em ritmo acelerado, e tem obtido destaque por parte das empresas e de estudiosos. Torres ainda considera que o marketing de incentivo é:

[...] uma alternativa final, quando todo o restante não vai bem. É a ferramenta do 'vai ou racha' e tem crescido significativamente em função de sua efetividade, velocidade de resposta e da principal característica: autopagável.(TORRES, 2000,p.8)

A análise dessa autora ajuda a dimensionar o tamanho do mercado mundial de promoções, setor que movimenta cerca de US\$300 bilhões anuais (MESQUITA, 2006). Segundo Crescitelli (2002, apud Cobra, 2002, p.10), em 1997, o marketing de incentivos rendeu US\$22,8 bilhões só nos Estados Unidos.

Esse mesmo mercado no Brasil rende cerca de US\$ 2 bilhões por ano, sendo que $20 \%$ desse valor são referentes às viagens de incentivo (ABGEV apud TASSITANI, 2008). E esses números só tendem a crescer com estratégias públicas mais efetivas e apoio institucional.

Um estudo realizado pela SITE - Society of Incentive \& Travel Executives (apud BARINI, 2008), associação mundial de pesquisa e educação na área de incentivos, 
mostra que $92 \%$ dos trabalhadores pesquisados revelaram ter atingido suas metas graças a programas de incentivo, enquanto $57 \%$ das empresas pesquisadas relataram ter atingido ou ultrapassado suas metas. Esse mesmo levantamento revelou que os programas de incentivo podem melhorar o desempenho individual do funcionário em $27 \%$ e as equipes, em cerca de $45 \%$.

Para o cumprimento de tais metas e obtenção de melhores resultados, as empresas vêm motivando seus funcionários por meio de prêmios de reconhecimento a excelência profissional. Ansarah salienta que:

[...] As empresas vêm se preocupando em incentivar e premiar o
bom desempenho de seus colaboradores com opções
diferenciadas, que proporcionam aos participantes das campanhas
momentos de verdadeira emoção e gratificação.
(ANSARAH,1999,p.57)

Com esta citação, a autora ratifica a importância do bom planejamento dessas ações, visto terem o papel de emocionar os contemplados.

Para os colaboradores ${ }^{3}$, participar de um programa de incentivo consiste, basicamente, em ser desafiado a atingir determinados objetivos, estimulados pela possibilidade de ganhar um prêmio de valor intangível.

Assim, quando uma empresa desenvolve programas motivacionais, surgem questionamentos de qual seria o melhor prêmio. O prêmio oferecido a vendedores de cosméticos podem não despertar o mesmo interesse em vendedores de automóveis. Visto que cada um desses dois grupos de vendedores tem um determinado perfil.

O departamento de relações humanas de uma empresa deve primeiramente ter meios de detectar o perfil de seus funcionários, o que se denomina briefing

Uma das formas propícias e difundidas na atualidade para premiar ou reconhecer a excelência profissional, com um diferencial de forte apelo emocional e psicológico, são as viagens de incentivo, que proporcionam aos vencedores o lazer e o descanso merecidos, em meio a atividades grupais prazerosas e altamente socializadoras.

${ }^{3}$ Entende-se por colaboradores os funcionários de uma empresa 
Estudos que medem o impacto de programas de incentivos indicam que os prêmios em dinheiro são considerados pelos colaboradores até no máximo um ano, carros e outros bens duráveis têm recall de aproximadamente quatro anos, enquanto que as viagens permanecem "vivas" na memória do beneficiado por até dez anos. Afinal, viagens rendem fotos, histórias divertidas, filmes, etc. (CALVO, 2006).

Assim, aborda-se a seguir a interface entre o marketing de incentivo e o turismo.

\subsubsection{O marketing de incentivo e o turismo}

O marketing de incentivo é aplicado, via de regra, sob forma de uma campanha, que por sua vez será composta de uma série de atividades, ações e materiais de apoio, cujo papel principal será "manter aquecida" a motivação e a competição. Dentre as atividades, são os eventos que recebem o maior destaque.

Assim, a AMPRO (s.d.), em seu Manual de Viagens de Incentivo recomenda que esta campanha seja lançada em um evento: "Para obter maior eficácia, recomendase lançar uma campanha através de um evento, pois o evento é um momento mágico, que cria sinergia e entusiasmo nas pessoas."

E é partir deste ponto que se inicia o cruzamento das atividades do Marketing de Incentivo com o turismo, em especial com o Segmento de Negócios e Eventos. Ora, se os eventos pretendem a imediata sensibilização dos participantes e a valorização dos mesmos, quanto mais impactante for este começo, maior a expectativa e os benefícios gerados. E esse impacto pode ser criado por meio de um evento singular, muitas vezes realizado em um local inusitado ou muito valorizado pelo público-alvo. O evento de lançamento pode ser também uma amostra do que será obtido com o bom desempenho, e não raro envolve deslocamento do grupo para uma outra cidade, incluindo hospedagem em hotéis de boa categoria e resorts, mesclando capacitações com atividades interativas de grupos (gincanas, competições entre equipes, desafios) que utilizam práticas de turismo esportivo, ecoturismo e aventura.

Mas são as viagens, que se inserem perfeitamente neste escopo de grandes premiações, quando então, recebem a denominação de viagens de incentivo e destacam-se como as maiores responsáveis pela conexão da atividade turística com a de incentivo, alvo da cobiça dos grandes destinos internacionais. 
Como vantagem competitiva sobre as demais recompensas (bônus financeiros e produtos), as viagens oferecem a experiência vivencial e, conforme estudos publicados pela Incentive House - empresa pertencente ao Grupo Accor e especializada em Marketing de Incentivo e atuante há mais de 20 anos no mercado brasileiro de incentivos- permanecem por mais de 10 anos na memória dos participantes (GOLRH, 2003).

Cabe ressaltar ainda que, embora se trate de uma viagem de lazer, o turismo de incentivo é usualmente atrelado ao segmento de negócios e eventos, pois sua motivação tem origem em ambiente profissional e as despesas são pagas pela empresa e não pelo indivíduo.

O turismo de incentivos foi melhor detalhado no item a seguir.

\title{
2.5.Turismo de Incentivo
}

Conforme anteriormente apresentado, o Turismo de Incentivo é aquele constituído por viagens-prêmio concedidas com o objetivo de incentivar 0 desempenho profissional e/ou recompensar o cumprimento de metas como cota de venda para o pessoal de vendas, de compra para consumidores, melhoria de padrões qualitativos, etc.

Neste sentido, Hoeller descreve:

\begin{abstract}
São viagens para premiar ou reconhecer a excelência profissional com um diferencial de forte apelo cultural emocional e psicológico que proporcionam aos vencedores o lazer e o descanso merecidos em meio às atividades grupais prazerosas e altamente socializadoras.(HOELLER apud ANSARAH,1999, p.57)
\end{abstract}

Como pode ser percebido, apesar da ligação do Turismo de Incentivo com o segmento de negócios e eventos, o desfrute da viagem de incentivo se assemelha a uma viagem de lazer, tendo como grande diferencial a exclusividade. $O$ ineditismo e particularidade dessas viagens é que farão com que as pessoas se sintam especiais e valorizadas.

O Ministério do Turismo ainda não possui um conceito para este segmento, sendo o 
do Ministério das Relações Exteriores (MRE) o único existente em âmbito governamental. Segue-se:

É o segmento do turismo constituído por programas e atividades para empresas ou organizações, com o intuito de motivar ou premiar funcionários ou equipes para que metas de produção ou qualidade sejam atingidas. (BRASIL, s.d)

Com enfoque na meta a ser alcançada, Vaz (1999) diz que as viagens de incentivo recompensam as pessoas com objetos que marcam uma façanha realizada. Baseiam-se em viagens de reconhecimento e recompensa.

No Brasil, o segmento é articulado pela Associação de Marketing Promocional (AMPRO) ${ }^{4}$, a qual está submetido o Comitê Brasileiro de Operadoras de Incentivo. Essa associação diz que Turismo de Incentivo:

\begin{abstract}
"É a recompensa, geralmente final, de uma campanha que prima pela excelência e qualidade. Seu apelo é emocional, é a lembrança registrada na memória do premiado que pode durar por até 12 anos e, assim, marcar sua vida e de seu acompanhante, garantindo uma fonte de melhoria no rela-cionamento pessoal, comercial e maiores lucros para a empresa." (AMPRO)
\end{abstract}

Nesta citação, a AMPRO afirma e aposta no valor residual das viagens de incentivo.

Já a SITE, Society of Incentive Travel Executives, associação internacional que congrega todo o trade de incentivos utiliza-se do conceito de Ricci e Holland (1992) que definem viagens de incentivo como:

\footnotetext{
"uma moderna ferramenta administrativa usada em campanhas de aumento de produtividade, que oferece viagens como prêmio aos participantes mais bem sucedidos em troca do desempenho mostrado na obtenção de melhores resultados." (apud ANSARAH, 1999, p. 59.)
}

A viagem de incentivo tem como peculiaridade não ser uma opção de compra do viajante, mas sim uma conquista, e, como tal, deve ser negociada pelos planejadores da campanha motivacional da empresa em parceria com empresas especializadas em viagens de incentivo.

${ }^{4} \mathrm{~A}$ AMPRO não é a única associação que congrega o trade de incentivo, como foi abordado no item 2.5 .13 
Assim, entende-se que as viagens de incentivo têm peculiaridades próprias que foram abordadas nos itens a seguir

\subsubsection{Histórico das Viagens de Incentivo}

A idéia de motivar colaboradores por meio de viagens de incentivo foi originada nos Estados Unidos. De acordo com Ansarah (1999,p.58), o primeiro registro data de 1906, quando a empresa National Cash Register Company of Dayton, em Ohio, premiou 70 vendedores com alfinetes de diamantes, além de uma viagem à matriz da empresa em Nova lorque. Entretanto, durante as décadas de 30 e 40, observouse um declínio nas iniciativas desse tipo devido à queda da bolsa de valores em 1929 e também ao período pós-guerra. Apenas na década de 60 as viagens de incentivo retomaram seu crescimento.

Este crescimento motivou a criação de organizações como a SITE (Society of Incentive and Travel Executives), com sede em Nova lorque cujo principal objetivo é promover e apoiar o desenvolvimento das viagens de incentivo e que foi melhor abordada no item a seguir.

No Brasil esta atividade tem aproximadamente 33 anos, pois segundo o Sr. Ibrahim Georges Tahtouh, diretor do Comitê de Operadoras de Viagens de Incentivo da AMPRO em entrevista à revista eletrônica Tudo.com (BARINI, 2008) neste país a atividade é desenvolvida no Brasil desde 1976, mas só agora chegou ao seu ponto de maturação e entendimento da importância para a economia e para o turismo.

Atualmente, a adesão a tais programas ainda é discreta por parte das empresas nacionais, porém grande parte das multinacionais já aderiu, premiando seus colaboradores com roteiros no Brasil e no exterior. As multinacionais, em maior quantidade, uma vez que o produto doméstico ainda goza de preços elevados na relação custo-benefício, segundo Ibrahim.

Um exemplo nacional é a Bradesco Seguros que conquistou o Globes Awards como Melhor Atividade Motivacional para Equipes de Vendas, envolvendo 35 mil corretores em todo o Brasil, e cujo prêmio foi uma viagem com acompanhante para uma ilha de Búzios, transformada em "Ilha Bradesco Seguros" . 


\subsubsection{Características de uma Viagem de Incentivo}

A principal característica de uma viagem de incentivo é o seu caráter exclusivo, projetado e customizado especialmente para os ganhadores em todos os detalhes. Estes desfrutarão como prêmio momentos difíceis de serem alcançados, por exemplo, através da compra de um simples pacote de férias. Estas viagens devem contemplar atividades às quais as pessoas não teriam acesso, tais como jantares em monumentos históricos ou cenários naturais, competições esportivas ou presença de personalidades em eventos.

A maioria dos pacotes garante muita tranqüilidade e comodidade para os colaboradores contemplados. Oferecem invariavelmente itens como transporte (aéreo, terrestre, ou marítimo); hospedagem durante todo período da viagem, serviço de "transfer" (em táxis, ônibus ou vans), coquetel de boas-vindas, opções de entretenimento e compras, refeições, acompanhamento de guias durante toda a viagem e seguro viagem.

São escolhidos os melhores hotéis, os restaurantes mais badalados, os passeios imperdíveis, todos os "transfers" exclusivos para o grupo, podendo chegar ao requinte de ter o cardápio pré-selecionado para evitar constrangimentos com a dificuldade de uma língua estrangeira, quando o destino é internacional.

A presença do acompanhante também é fundamental, já que eles dão o apoio durante a campanha para que os participantes se sintam encorajados a superar suas metas, e nada mais justo que compartilhar desses momentos especiais. Portanto, a escolha do destino tem que ser compatível com o perfil do público.

Todos esses diferenciais é que vão fazer com que os premiados se sintam verdadeiros vencedores. Eles voltarão com a sensação de serem pessoas privilegiadas, pois, de outra forma, não conseguiriam realizar aquele sonho.

Essas características tornam essas viagens mais onerosas e por isso geralmente são realizadas na baixa temporada, pois nesta estação é mais fácil conseguir uma melhor prestação de serviços por parte dos fornecedores, já que o fluxo turístico é menor, e os estabelecimentos precisam ocupar as vagas disponíveis, proporcionando assim tarifas mais baratas. 
A viagem de incentivo como prêmio pode ser individual ou em grupo e seu custo vai variar de acordo com os serviços oferecidos.

Além disso, para as empresas, as viagens de incentivos geram os seguintes benefícios (HOELLER apud ANSARAH, 1999, p.59):

- Colaboradores motivados e as conseqüências desta motivação

- O efeito residual atuará como incentivo para outras campanhas

- Novas experiências dos colaboradores através do contato com diferentes culturas

- Integração entre colaboradores e/ou cliente e/ou fornecedores

- Envolvimento de terceiros com a empresa (no caso de viagens que incluem familiares)

- Possibilidade de se conhecer outras unidades da empresa ou até mesmo de participar de eventos do setor.

Já para os colaboradores as vantagens são:

- Apelo emocional causado pela possibilidade da viagem

- Valor residual

- Reconhecimento demonstrado pela empresa

- Status

- Fuga da rotina de trabalho

Para os fornecedores de serviços turísticos, listam-se as seguintes conveniências:

- Aumento de ocupação durante a baixa sazonalidade nos meios de hospedagem

- Aumento do número de passageiros nos meios de transportes 
- Maior flexibilidade na negociação de tarifas

- Garantia de ocupação com bastante antecedência, uma vez que este tipo de viagem costuma ser bem planejada antecipadamente

Esses fatores demonstram que todos os agentes envolvidos no Turismo de Incentivo só têm a ganhar, uma vez que movimenta empresas, colaboradores e equipamentos turísticos.

\subsubsection{Agentes e tomadores de decisão}

Como explicado anteriormente no item "O marketing de Incentivo e o Turismo", os eventos preparatórios e a viagem de incentivo são atividades integrantes de uma campanha motivacional, sendo que esta última é, via de regra, a premiação final.

A campanha de motivação é criada por empresas especializadas em marketing de incentivo, podendo ser exclusivamente dedicadas a esta finalidade ou constituir-se um departamento especializado dentro de uma empresa de marketing promocional, agências de publicidade, ou empresa organizadora de eventos corporativos.

Mas todas estas empresas valem-se de um operador de turismo especializado em incentivos. O Manual de Viagem de Incentivos digital publicado pela AMPRO, estabelece os diferentes papéis dos agentes envolvidos, definindo a empresa especializada em viagens como a tomadora de decisão sobre o destino para o qual será realizada a viagem, a partir das informações subsidiadas pela empresa coordenadora da campanha, de forma que este local seja compatível com o perfil dos participantes e objetivo da empresa.

Registra-se ainda situações onde o próprio cliente (empresa não turística) cria a campanha dentro de um departamento da empresa (marketing, $\mathrm{RH}$ usualmente), coordenada por um profissional especializado. Nestes casos, é comum que a agência de turismo que atende regularmente as demandas de viagens da empresa seja acionada para a estruturação do roteiro da viagem, no caso de ser esta a premiação.

De acordo com a ABC Fly - Viagens e Incentivos ${ }^{5}$, também existem empresas de

${ }^{5}$ ABC Fly- Viagens e Incentivos. Dispoível em: <http://www.abcflyviagens.com.br/corpora.htm> 
recursos humanos especializadas em criar, implantar, gerenciar e documentar programas de incentivo com a intenção de motivar e reconhecer a excelência das pessoas no trabalho.

De qualquer forma a atividade de incentivo envolve grande parte da cadeia produtiva do turismo pois utiliza hospedagem, transporte, alimentação, atrativos, locais para realização de eventos e atividades, entre outros.

\subsubsection{Público- alvo}

O marketing de incentivo é usualmente direcionado para colaboradores (em especial equipes de vendas) e apóia-se no fortalecimento do comprometimento para com a empresa. Contudo, estes programas demonstram sucesso não somente em aumentar vendas, mas também na área de recursos humanos para reduzir rotatividade de funcionários, melhorar produtividade, atrair candidatos qualificados, e oferecer prêmios de tempo de serviço e melhoria no trabalho. E pode ainda ser focado em parceiros , como forma de reconhecimento de sua participação nos bons resultados, ou em grandes clientes e até consumidores finais, nestes casos, visando à melhoria do relacionamento e principalmente a fidelização.

Utilizam-se constantemente de viagens de incentivos: seguradoras, empresas de tecnologia; empresas de serviços médicos; montadores e revendedores de veículos; empresas de software e informática; construtoras e empresas de material de construção; empresas de logística.

\subsubsection{Critérios para seleção do destino}

O destino da viagem de incentivo deverá ser adequado ao perfil do público alvo. Este perfil deve ser definido por meio de aplicação de entrevistas, que avalia nível cultural, sexo, nível econômico, graduação. Destinos considerados excepcionais por um grupo poderão ser extremamente frustrantes por outros. Quanto mais singular, mais personalizada a viagem, maior o impacto e maior o resultado obtido pela empresa, visto que o premiado acaba sendo um propagador do benefício, reforçando a motivação dos demais, que esperam em uma próxima oportunidade serem agraciados também.

A imagem do destino e seus atributos, além dos diferenciais competitivos explorados 
pelo mesmo em suas campanhas promocionais, possuem um peso importante, bem como o ineditismo, já abordado anteriormente.

Além destes fatores essenciais, alguns critérios básicos devem ser observados:

- Facilidades de deslocamento e logística

- Hotelaria com boa infra-estrutura

- Custos dentro do orçamento definido pela empresa

- Atividades interessantes

- Equipamentos culturais e/ ou cenários naturais que possuam política de realização de eventos facilitada.

Por questões de custos e logística, é bastante comum que o destino do evento seja na cidade ou entorno da matriz do cliente. A própria visitação às instalações da empresa, com a realização de atividades nas suas dependências e o contato com os dirigentes, já é visto como uma ação motivacional.

Outra tendência é a realização de viagens de incentivo após a visitação a uma importante feira de negócios do setor da empresa. Desta forma, os gastos com a viagem são diluídos na capacitação que os participantes recebem pelo acesso às informações proporcionadas pela feira. Os destinos então tendem a ser o mesmo da feira, cidades vizinhas com bom apelo turístico ou com acesso logístico facilitado a partir desta. Destinos como São Paulo, com alta concentração de feiras de negócios de renome internacional, e destinos turísticos próximos possuem significativo diferencial competitivo neste cenário.

\subsubsection{Duração da viagem}

Recomenda-se que a duração de uma viagem de incentivo esteja limitada a oito dias, pois deve-se ter em mente que o participante é um profissional relevante na empresa e, por este motivo, não deve ficar afastado por muito tempo. Trabalha-se fundamentalmente a qualidade do tempo sobre a quantidade.

Para Elisete Hoeller (1999), 50\% das viagens de incentivo duram entre 4 e 7 dias, e 
outros $40 \%$ duram apenas 3 dias. Mas a autora compreende que apesar desse tempo ser considerado curto, é aceitável. Pois, muitas vezes, as empresas não têm como liberar um número elevado de funcionários por períodos muito longos.

E, segundo Souza:

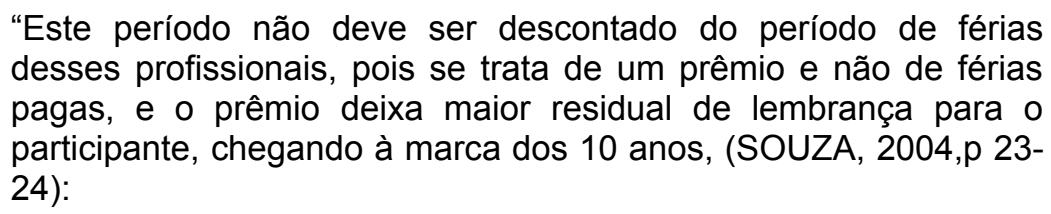

Já que a viagem é uma premiação ao colaborador, não pode haver nenhum ônus, como o desconto de dias de férias.

\subsubsection{Tipo de viagem}

É possível encontrar viagens de incentivo individuais mas a grande maioria ocorre em grupos pequenos, de até 20 pessoas. Isso se deve ao fato de que a viagem com os demais funcionários da empresa fortalece os laços emocionais e gera integração. A empresa tem total interesse na retenção de bons funcionários e a criação ou fortalecimento de vínculos favorece este processo. Essas viagens possuem orçamentos mais elevados.

As viagens individuais geralmente são iniciativas de empresas de pequeno porte ou departamentais. Deste modo, na maioria das vezes, não há a contratação de agências de incentivo, pois a própria empresa toma as decisões.

Também algumas empresas viabilizam a participação de um acompanhante para que a viagem se torne ainda mais memorável.

\subsubsection{Período de realização das atividades de incentivo}

A premiação por resultados financeiros e econômicos usualmente ocorre por ocasião do fechamento do ano fiscal da empresa, quando o faturamento é checado e as performances individuais podem ser medidas. No Brasil, e em vários países da América Latina este período corresponde a dezembro - fevereiro.

No entanto, em se considerando o receptivo internacional, o calendário do ano fiscal 
dos países-alvo deve ser analisado.

De acordo com a pesquisa de 2006, os meses em que o Brasil mais recebe turistas de incentivo são outubro e março, respectivamente.

\subsubsection{Turismo de Incentivo no Mundo:}

A tendência é que os destinos mais diferenciados continuem sendo muito visitados pelos turistas de incentivo. Hoeller (apud, ANSARAH,1999, p.63) aponta que destinos exóticos são cada vez mais procurados, e isso se deve ao fato de que roteiros tradicionais muitas vezes já foram visitados pelos participantes. Assim, na década de 90, os destinos mais procurados pelos norte-americanos eram: Havaí, Acapulco, St. Marteen, Nassau, Flórida, Califórnia e Puerto Vallarta.

Já dentre as preferências dos europeus estavam: Londres, França, Espanha e Alemanha. Além de Estados Unidos e Caribe.

Sobre essas diferenças de escolha entre norte-americanos e europeus, a autora Helena Souza (2005) resume:

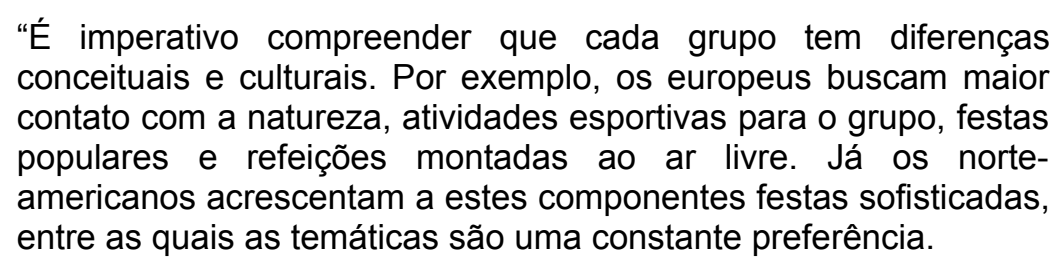

Além deste exotismo, os lugares onde as grandes empresas têm sede, quando oferecem atrativos, também são bastante utilizados. Neles são feitas visitas às empresas e grandes eventos, por exemplo.

Dois destinos foram analisados durante esta pesquisa: Cape Town (África do Sul) e Melbourne (Austrália). Escolheu-se esses destinos devido às similaridades desses países com o Brasil.

\subsubsection{Cape Town}

Desde 2005 o Turismo de Incentivos foi reconhecido pelos órgãos públicos de turismo da cidade.

A priori, foi feita uma pesquisa com os 30 operadores de incentivo identificados na 
cidade. O objetivo desta pesquisa era traçar um panorama do comportamento do segmento.

A pesquisa indicou que sua principal demanda provinha da Europa Ocidental, mais especificamente da Alemanha, Inglaterra e Irlanda, Escandinávia, Áustria, Suíça, Holanda e França; da América do Norte, ou seja, Estados Unidos e Canadá, e da América do Sul, exclusivamente do Chile.

Os principais ramos das empresas que utilizaram o serviço de incentivo foram: farmacêuticas, bancos, finanças e telecomunicações.

Segundo esta pesquisa, os principais concorrentes da África do Sul no segmento de Incentivos são: México, Brasil, Tailândia, Argentina, Turquia, Portugal, Nova Zelândia, Emirados Árabes e Marrocos.

Desde então, a África do Sul como um todo tem se mobilizado na captação de viagens de incentivo tendo como principal apelo seus safáris e atividades ligadas à selva. Com o slogan "South Africa - It's possible", este país se abre para as criativas idéias dos planejadores de incentivo, ou seja, tudo que se imaginar fazer na África do Sul como um almoço no meio da savana junto aos elefantes, é possível.

A Copa do Mundo de 2010 também vem representando um produto de viagens de incentivo.

\subsubsection{Melbourne}

A cidade australiana de Melbourne aborda o turista de incentivo através de 5 programas:

\section{- Melbourne Sights}

Por este programa, o turista é convidado a conhecer os pontos turísticos e as paisagens da cidade como monumentos, shoppings, passeios de helicóptero, etc.

\section{- Melbourne Sounds}

Este programa oferece corridas de carros, jogos de cricket, passeios de moto, dentre outras atividades. 
- Melbourne Scents

Este programa proporciona ao turista oportunidades de conhecer a cultura australiana, pois ele inclui visitas à comunidades aborígenes e à zona rural.

- Melbourne Touch

Contato com cangurus e uma tarde em um SPA fazem parte deste programa.

- Melbourne Taste

Os participantes deste programa desfrutarão de aulas de culinária e degustações de vinho.

Para estimular a captação de grupos de incentivo o governo de Melbourne oferece banners de boas-vindas no aeroporto, cartas convites assinadas pelo Governador, uma cerimônia aborígene de boas-vindas, dentre outras ações.

\subsubsection{Principais emissivos}

Elisete Hoeller (apud ANSARAH, 1999, p.63) aponta que os principais mercados emissivos de turistas de incentivo são: Estados Unidos, responsável por $52 \%$ dessa demanda, seguido por Inglaterra, França, Itália e Alemanha.

Esse fato se deve, principalmente, por estarem concentrada na América do Norte e na Europa grande parte das empresas multinacionais do mundo.

\subsubsection{Turismo de Incentivo no Brasil}

De acordo com Souza (2005, p. 22), os turistas de incentivo:

“(...) vêm principalmente para o Rio de Janeiro. O circuito clássico dos franceses, cujos grupos são menores (média de 60 a 70 pessoas) do que os dos norte-americanos (150 a 200 pessoas) é o Rio de Janeiro, Salvador e Foz do Iguaçu. Os portugueses vão mais para o Nordeste do que para o Rio de Janeiro."

Confirmando a afirmação acima, na maioria dos sites visitados de operadoras de incentivo brasileiras, encontra-se além de roteiros para o Rio de Janeiro e Bahia, programas de incentivo para o Nordeste de uma forma geral. 
A floresta Amazônica, com suas infinitas oportunidades, também é destino recorrente das operadoras brasileiras;

É possível afirmar que o Brasil, por agregar diferentes opções de turismo, possui enorme potencial para o segmento de incentivos, entretanto ainda inexplorado.

\subsubsection{A legislação sobre o tema}

Há apenas uma legislação existente que se refere à distribuição gratuita de prêmios, mediante sorteio, vale-brinde ou concurso, a título de propaganda, consubstanciada na Lei $n^{\circ}$ 5.768, de 20/12/1971, regulamentada pelo Decreto $n^{\circ} 70.951$, de 09/08/1972. Tal legislação estabelece que a distribuição gratuita de prêmios, a título de propaganda quando efetuada mediante sorteio, vale-brinde, concurso ou operação assemelhada, dependerá de prévia autorização do Ministério da Fazenda. Entretanto esta legislação não se aplica ao mercado de turismo de incentivos, já que a premiação independe de fatores de sorte ou azar (sorteio, vale-brinde etc.).

Já ações de marketing de incentivo propriamente dito, e por conseqüência o Turismo de Incentivo, carecem de lei específica. Nesse sentido, há um Projeto de Lei de número 6.746/2006 que regula a concessão espontânea de prêmios por produtividade no âmbito de programas e projetos de incentivo ao desempenho dos trabalhadores.

\subsubsection{Associações de Incentivo}

Do ponto de vista governamental, não foram identificadas políticas públicas em nível federal direcionadas ao desenvolvimento desse segmento turístico.

A menção ao turismo de incentivo nas páginas web e materiais promocionais dos diversos destinos brasileiros é raríssima. Ao contrário de países e cidades turísticas relevantes no cenário internacional, os destinos turísticos brasileiros, por meio de seus CVBx- Convention \& Visitors Bureaux - e Secretarias de Turismo raríssimas vezes mencionam incentivo em seus portais web ou materiais promocionais.

Matéria publicada na coluna "Viagem e Aventura" do jornal " O Estadão" de 26 de fevereiro de 2002 afirma que o Instituto Brasileiro de Turismo (Embratur) reconheça a existência do turismo de incentivo, ainda não há estatísticas no país sobre quanto 
ele movimenta em recursos financeiros, nem sobre a quantidade de turistas envolvidos. Desta forma, esses números acabam diluídos nas estatísticas das contas comerciais e nas de eventos.

Já os empresários do segmento brasileiro de viagens de incentivo encontram-se organizados em várias associações de classe, sem que haja uma liderança entre elas e da mesma forma inexiste uma entidade encarregada exclusivamente desta atividade.

Listam-se essas entidades:

- $\mathrm{ABEOC}$ - Associação Brasileira de Empresas Organizadoras de Eventos

Engloba tanto organizadores de eventos associativos, como corporativos e fornecedores para eventos. Possui grande capilaridade com entidades regionais em vários estados da Federação. Promove um Congresso Anual, realizado durante a semana dos Eventos. Não identificado comitê especifico de incentivos.

- ABGEV - Associação Brasileira de Gestores de Viagens Corporativas

Tem a particularidade de agregar gestores de viagens corporativas, organizadores de eventos, fornecedores e cliente. Dentre os seus 09 comitês de trabalho há um específico de Gestores de Eventos. Não foi identificado, em maio de 2009, comitês específicos de viagens de incentivo. ABGEV faz parte do Paragon Partnership, um grupo mundial de Associações de Viagens de Negócios, liderados pela conceituada NTBA (National Business Travel Association, E.U.A), com mais 11 importantes entidades: ABGEV (Brasil), ABTA (Austrália/Ásia), ABTA (Áustria), AFCV (França), CBTA (Canadá), DBTA (Dinamarca), FBTA (Finlândia), IBTA (Espanha), NATM (Holanda), SBTA (Suécia) e VDR (Alemanha).

\section{- AMPRO - Associação de Marketing Promocional}

Agrega empresas especializadas em marketing de incentivo, agências de publicidade, empresas de premiação, organizadoras de eventos corporativos. Há um comitê especializado em Turismo de Incentivo. A entidade é a promotora do EBEI Encontro Brasileiro das Empresas de Incentivo, reúne eventos da principais entidades do segmento de negócios e eventos. 
Por esta associação possuir um comitê especializado em Turismo de Incentivo e ser pioneira em planejar a formação de um Bureau de Incentivo, a AMPRO foi a associação escolhida para ser foco desta pesquisa.

- FAVECC - Fórum das Agências de Viagens Especializadas em Contas Comerciais

Tem por objetivo a busca de soluções conjuntas visando facilitar as viagens de negócios dos clientes executivos. Em maio de 2009, o website da entidade registrava 25 agências associadas, que somadas atingem 67 filiais e 346 postos de serviços dentro de empresas. As associadas estão distribuídas em São Paulo, Campinas, São José dos Campos, Rio de Janeiro, Belo Horizonte, Brasília, Salvador, Recife, Maceió,Vitória, Fortaleza e Curitiba. Em 2008, de acordo com o fórum, estas empresas geraram um volume de negócios diretos de $\mathrm{R} \$ 4.970$ bilhões. O FAVECC produz estatísticas mensais e nacionais, disponibilizadas em sua página web, sem senha de acesso.

- BITO - Brazilian Incoming Tour Operators

Reúne as principais operadoras de turismo receptivo do país, algumas delas focadas em turismo de incentivo.

Dentre as entidades internacionais, destacam-se:

- SITE (Society of Incentive Travel \& Executives).

A organização agrupa representantes de diversas especialidades: consultorias de marketing, agências de incentivo, de promoção e propaganda, companhias de transportes, operadoras de turismo, bureaux, redes hoteleiras e empresas de lazer, com um total de aproximadamente 2100 membros em 82 países.

De acordo com a própria SITE, esta grande adesão se deve ao fato de:

"Site is the only global authority connecting motivational experiences with business results (...) Site serves as the source of expertise, knowledge and personnel connections that will catapult and sustain professional growth, and help build the value of extraordinary motivational experiences worldwide." (SITE)

\footnotetext{
6 "A Site é a única autoridade global que conecta experiências motivacionais com resultados de negócios. (...) A Site serve como a fonte de expertise, conhecimento e conexões pessoais que irão catapultar e sustentar o
} 
Deste modo, esta sociedade congrega diversos grupos de discussão acerca do tema motivação, como o SITE Academy for Young Leaders, que foca na formação dos futuros profissionais do mercado de incentivos.

- Incentive Federation Inc.

A Incentive Federation foi fundada com o intuito de promover, proteger, e incentivar pesquisas acerca dos segmentos de promoção e incentivos. Esta organização defende e divulga esses assuntos através de pesquisas e publicações.

Embora melhor articuladas, as associações internacionais do segmento também não são especializadas em turismo de incentivo.

\subsubsection{Principais Eventos do Setor}

As feiras internacionais estão entre os principais eventos do segmento de incentivos. Entre as várias definições existentes para as feiras, adota-se nesta pesquisa, a da Confederação Brasileira de Conventions \& Visitors Bureaux, através da qual as feiras são um meio pelo qual os clientes visitam seus fornecedores.

Dentre as principais feiras internacionais do segmento de Incentivos, pode-se destacar:

- CONFEX

- IMEX

- EMIF - European Meeting Industry Fair

- Feria Internacional del Mercado de Reuniones e Incentivos de América Latina y el Caribe - FIEXPO Latino America

- $\quad$ MITM AMERICAS - Meetings \& Incentive Trade Market

- IT\&ME - The Motivation Show

crescimento profissional, e auxiliar na construção do valor de experiências motivacionais extraordinárias a nível mundial" (Tradução Livre) 
- BTC International

Já em âmbito nacional, os principais eventos do setor são:

- LACIME: Latin America and Caribbean Incentive \& Meetings Exhibition

- LACTTE - Encontro Latino-Americano de Viagens Corporativas e Tecnologia

- $\quad E B E I$ - Encontro Brasileiro de Empresas de Incentivos 


\section{MÉTODOS E TÉCNICAS DE PESQUISA}

As pesquisas podem ser fundamental ou aplicada. A fundamental busca o conhecimento pelo conhecimento e a pesquisa aplicada tem com meta o interesse prático, onde os resultados sejam aplicados na realidade (ANDER-EGG, 1978, p.33). Neste sentido, este trabalho tem como característica a pesquisa aplicada, ao sugerir estratégias reais para o Turismo de Incentivo no Brasil.

Procedeu-se, também a uma pesquisa bibliográfica em fontes primárias e secundárias, que embasam teoricamente o trabalho acerca dos temas turismo, motivação, segmentação, marketing de incentivo e turismo de incentivo. Todavia ressalta-se a limitação e a dificuldade em conseguir embasamento acadêmico e técnico sobre tema, pouco estudado e abordado no turismo. Segundo Filho e Santos:

\footnotetext{
"A pesquisa bibliográfica sempre será necessária em trabalhos científicos para se ter conhecimento prévio de qualquer assunto a ser tratado. Essas fontes bibliográficas, de acordo com eles, são "informações já escritas em livros, jornais e revistas, entre outros" (FILHO e SANTOS, 2003, p. 97).
}

Bervian e Cervo (2002) afirmam que a pesquisa bibliográfica tem como "objetivo encontrar respostas aos problemas formulados e o recurso é a consulta dos documentos bibliográficos" (p. 88). A fonte de informações sempre estará na forma de documentos escritos podendo ser impressos ou eletrônicos.

Sobre esse tipo de pesquisa, Marconi e Lakatos afirmam:

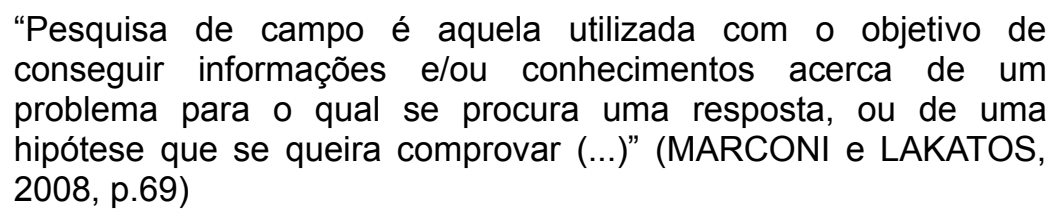

Ainda de acordo com essas autoras (2008, p.81), alguns estudiosos consideram a entrevista como o instrumento por excelência da investigação social e dependendo 
de como for conduzida, é muitas vezes superior a outros sistemas na obtenção de dados.

Realizou-se ainda, uma pesquisa quantitativa feita por esta autora juntamente com a acadêmica Shênia Patricia Cassiano de Oliveira, em 2006. Nesta investigação foram aplicados 14 questionários às principais agências de receptivo de Turismo de Incentivo no Brasil, sobre as características desse segmento.

\subsection{Delineamento da pesquisa}

A quase ausência de ações para o turismo de incentivos no Brasil é motivação inicial para esta pesquisa.

O segmento de incentivos brasileiro vem sendo trabalhado pela cadeia produtiva do turismo desde 1976, e movimenta cerca de $\mathrm{R} \$ 31$ bilhões ao ano (ABGEV apud TASSITANI, 2008)

Com estratégias públicas mais efetivas e apoio institucional, esse número só tende a crescer.

\subsection{Caracterização da organização, setor ou área}

Os dados foram coletados através dos seguintes meios:

O panorama atual do segmento em órgãos oficiais foi desenhado através de dados do Ministério do Turismo e do Embratur. Esses dados foram obtidos por alguns documentos internos e principalmente entrevistas com servidores.

O Ministério do Turismo foi criado em 2003 com o intuito de melhor organizar e estruturar o turismo nacional. É constituído por 2 Secretarias Nacionais: a de Políticas de Turismo e a de Programas de desenvolvimento do Turismo. 
O programa deste ministério que trata de segmentação e conseqüentemente de turismo de incentivos é o "Estruturação dos Segmentos Turísticos" que está incorporado ao macro programa "Regionalização do Turismo".

O Embratur - Instituto Brasileiro de Turismo - é uma autarquia subsidiada pelo Ministério do Turismo e cuja função é a promoção do Brasil no exterior como destino turístico.

Atualmente o instituto possui quatro diretorias: A Diretoria de Marketing, a Diretoria de Turismo de Negócios e Eventos, a Diretoria Administrativa, e a que mais será focada no presente trabalho: a Diretoria de Lazer e Incentivo.

Entrevistas também foram realizadas com 2 membros do Comitê de Operadoras de Viagens de Incentivo da AMPRO. Este comitê possui 9 associados.

A Confederação Brasileira de Conventions \& Visitors Bureaux é uma associação que congrega a maioria dos Conventions do Brasil. Estes Conventions têm por finalidade gerar negócios para suas localidades, seja através da captação de eventos, da formação de parcerias, etc.

\subsection{Caracterização dos instrumentos de pesquisa}

Como fonte de pesquisa utilizou-se publicações nacionais e internacionais que estão disponíveis tanto em meios impressos e/ou digitais.

Como instrumento de pesquisa foram realizadas entrevistas de caráter qualitativo, considerando assim a opinião do trade nacional acerca do tema pesquisado, pois segundo o IBOPE (Instituto Brasileiro de Opinião Pública e Estatística):

As pesquisas qualitativas são exploratórias, ou seja estimulam os entrevistados a pensarem livremente sobre algum tema, objeto ou conceito. Elas fazem emergir aspectos subjetivos e atingem motivações não explícitas, ou mesmo conscientes, de maneira espontânea. São usadas quando se busca percepções e entendimento sobre a natureza geral de uma questão, abrindo espaço para a interpretação. (Portal IBOPE)

Desta forma, justifica-se a escolha por se tratar de percepções e opiniões destes agentes acerca do Turismo de Incentivo 


\subsection{Procedimentos de coleta e de análise de dados}

A coleta de dados documental foi feita através de pesquisas na internet, publicações impressas e documentos internos do Ministério do Turismo e do Embratur.

As entrevistas foram previamente planejadas e realizadas por meio de reuniões ou por email, por esta pesquisadora durante o período de abril a junho de 2009. 


\section{APRESENTAÇÃO E ANÁLISE DOS DADOS DA PESQUISA}

\subsection{Apresentação da Pesquisa}

Conforme consta no tópico dedicado à explicação da metodologia adotada neste trabalho, procurou-se identificar a percepção dos atores envolvidos no segmento de Turismo de Incentivo no Brasil, por meio de pesquisa de campo através de entrevistas de caráter qualitativo. Como dados secundários utilizou-se pesquisa com operadoras de incentivo realizadas por esta pesquisadora em conjunto com a acadêmica Shenia Patricia Cassiano de Oliveira, em 2006 que objetivaram traçar um panorama do segmento no mercado nacional.

\subsection{Participantes do Estudo}

Representando o trade de incentivos brasileiro, foram entrevistados 2 responsáveis pelas operadoras de viagens de incentivo do comitê de Operadoras de Viagens de Incentivo da AMPRO.E também um representante da Confederação Brasileira de Conventions \& Visitors Bureaux.

A fim de considerar a opinião dos órgãos públicos, também participaram deste estudo um representante da gerência de Congressos, Negócios e Incentivos do Embratur, e um técnico da área de estruturação de produtos do mesmo instituto.

Pelo Ministério do Turismo, entrevistou-se um técnico responsável pelo Segmento Negócios e Eventos, e um representante da Diretoria de Marketing.

Já a pesquisa de 2006 envolveu 14 agências de viagens brasileiras especializadas no segmento de Incentivo.

\subsection{Análise dos Resultados da Pesquisa}

O universo da pesquisa compreendeu 7 pessoas de diferentes esferas do Turismo Brasileiro mas que de alguma forma estão envolvidos com o segmento de incentivo. 
Como dados secundários, utilizou-se uma pesquisa elaborada por esta pesquisadora em parceria com a acadêmica Shênia Patricia Cassiano de Oliveira, em 2006 com 14 agências de viagens especializadas em incentivo.

\subsubsection{Viagens de Incentivo $x$ Viagens Convencionais}

Os entrevistados foram unânimes ao serem questionados acerca do que diferencia uma viagem de incentivo dos outros tipos de viagem. Eles entendem, que assim como a teoria já previamente apresentada, essas viagens são premiações finais de um programa de incentivo, destinadas em sua maioria à colaboradores, clientes e parceiros de empresas.

Com este pensamento o representante da CBCVB, disse que “(..) uma viagem normal é aquela que o próprio viajante planeja, definindo roteiro, meio de transporte, tempo, etc. Já a viagem de incentivo é um prêmio, uma conquista e não é decidida por quem ganha, mas pela direção da empresa, que planejará uma viagem completa como forma de recompensa a um colaborador ou vários colaboradores que tenham atingido metas e contribuído com os objetivos da empresa".

O representante da gerência de Estruturação de Produtos do Embratur citou, 2 aspectos principais que diferenciam a viagem de incentivo das demais viagens de lazer. O primeiro é o "consumidor", cliente, ou demandante desse tipo de viagem. Ao contrário das viagens de lazer normais, quem demanda a organização de uma viagem de incentivo é normalmente um cliente corporativo (empresa) para seus funcionários.

A segunda diferença é quanto ao objetivo da viagem. Apesar de incluir atividades de lazer e entretenimento tal como uma viagem normal, o objetivo da viagem de incentivo é originário do objetivo da empresa/organização que usa a viagem como forma de premiação ou recurso motivacional ou para treinamento de seus funcionários.

Com foco nas especificidades de uma viagem de incentivo, a pesquisa de 2006, apresentou os seguintes resultados: 
Figura 2: O que diferencia uma viagem normal de uma viagem de incentivo.

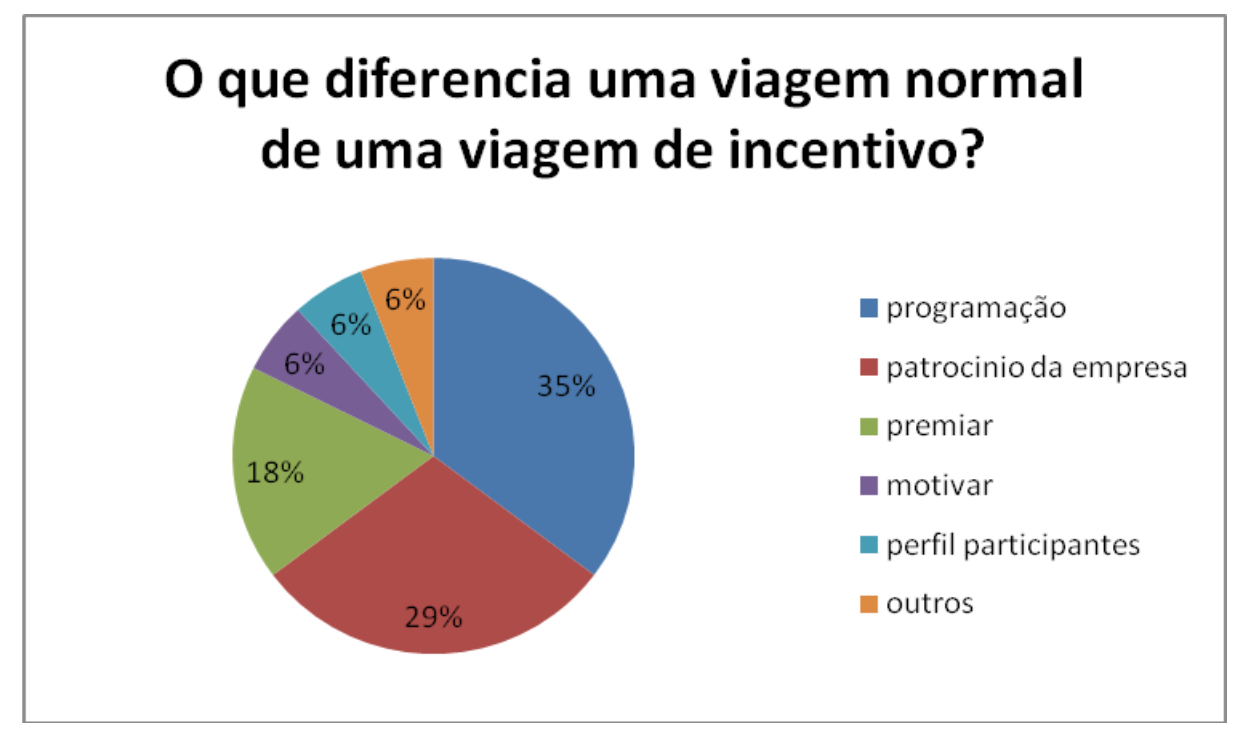

O gráfico acima evidencia o caráter único das viagens de incentivo, já que seu principal diferencial é a programação especialmente planejada para esse publico específico.

Também ganha destaque o fato dessa premiação ser patrocinada pelas empresas.

\subsubsection{Quanto custa uma viagem de Incentivo}

As características e detalhes mencionados no tópico anterior, assim como foi apresentado no referencial teórico, tornam as viagens de incentivo mais onerosas que outros tipos de viagens. Neste sentido, o representante da gerência de Segmentação do Ministério do Turismo afirmou em sua entrevista que:

\footnotetext{
"A viagem de lazer é geralmente planejada com mais antecedência, e talvez por esse mesmo motivo, todos os gastos são minimamente calculados, já que as pessoas têm que se preocupar mais com esse quesito. Nas viagens de incentivo, como os gastos são geralmente pagos pela empresa, podem ser realizados com menos preocupação."
}

E esses altos custos despendidos pelas empresas com os turistas de incentivo, foram analisados na pesquisa de 2006 e tabulados como se segue: 
Figura 3: Gasto médio do turista de incentivo.

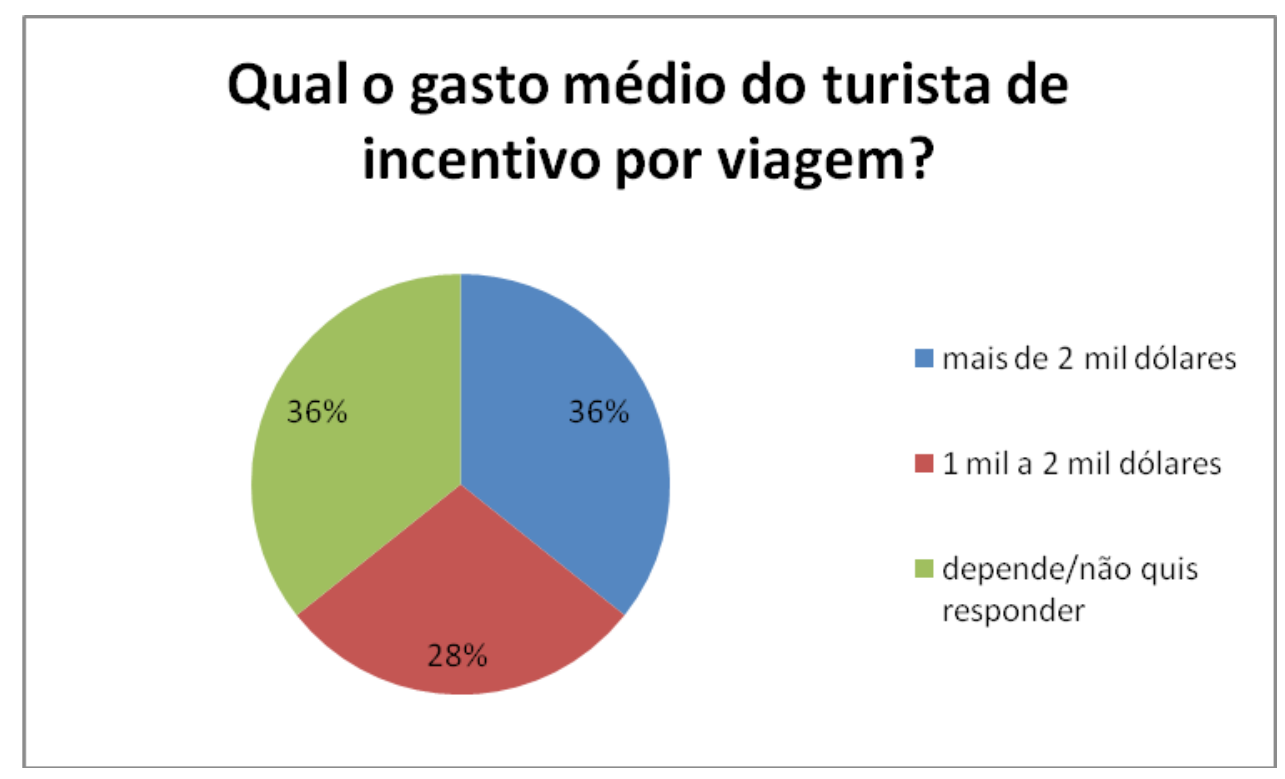

Os valores acima se referem ao gasto total da viagem desses turistas. Considerando que, segundo Hoeller (1999), 40\% destas viagens duram até 3 dias e custam um valor aproximado de US\$667,00 ao dia. Mesmo superestimando, esse seria um gasto muito superior aos US\$165,14 diários estimados para os turistas de negócios. (WERZBITZKI, 2009). O representante da Havas Creative Tours, escreveu em seu questionário em 2006, que já organizou viagens de incentivo cujas cifras ultrapassaram um milhão de dólares.

\subsubsection{Destinos Mundiais}

Em sua entrevista à esta pesquisadora, o representante do Comitê de Operadoras de Viagens de Incentivo da AMPRO, afirmou que os principais destinos de incentivo no mundo são: Miami, Orlando, Las Vegas, Chile e Paris. E ainda há destinos de oportunidade como a África do Sul, com seu apelo aos safáris e agora a Copa do Mundo de 2014; a China, potência emergente; a Índia; a Nova Zelândia e Dubai.

Estes destinos vão ao encontro da teoria de Hoeller (1999) que aponta que destinos exóticos são cada vez mais procurados, e isso se deve ao fato de que roteiros tradicionais muitas vezes já foram visitados pelos participantes

O entrevistado da Gerência de Estruturação de Produtos do Embratur, destacou em sua entrevista a ilha de St. Maarten, no Caribe que, segundo ela, possui uma grande 
diversidade de oferta para viagens de incentivo: "Uma vez que o destino é conhecido como hub para atividades náuticas, velas, regatas, algumas empresas promovem seus serviços como opções de atividades a serem incluídas em uma viagem de incentivos."

De maneira mais abrangente, o entrevistado da Diretoria de Marketing do Ministério do Turismo, lembra que destinos que possuem bons resorts também são preferências das agencias de incentivos. Este fato se deve aos resorts agregarem várias atividades em um único lugar.

\subsubsection{Destinos no Brasil}

Esta pesquisa constatou, por meio dos dados dos questionários de 2006, que lugares como Rio de Janeiro, Salvador e Foz do Iguaçu são os destinos preferenciais deste segmento no Brasil.

\section{Figura 4: Destinos Brasileiros}

\section{Quais os destinos mais procurados?}
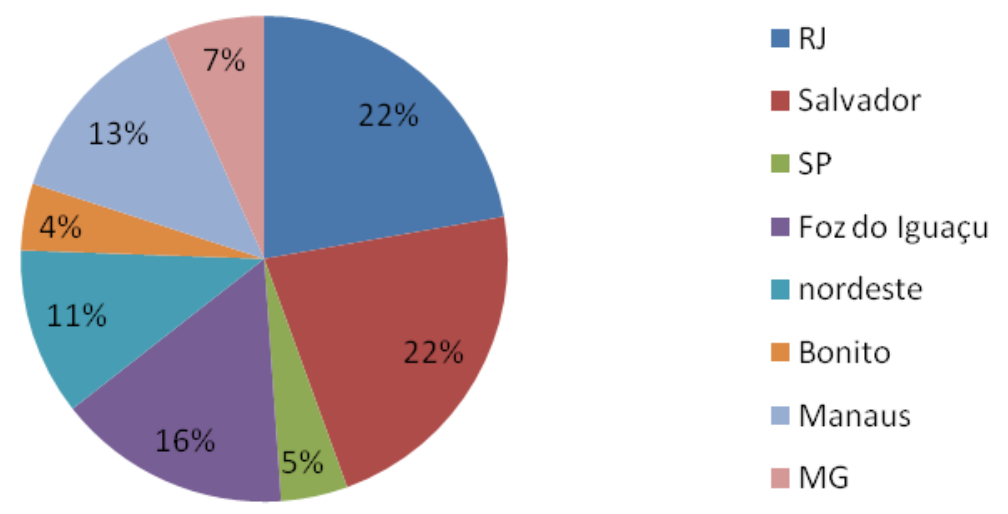

Dados esses que comprovam mais uma vez que a finalidade deste tipo de viagem é o lazer.

A Havas Creative Tours, afirmou ao responder seu questionário que, para sua empresa os principais destinos brasileiros de Incentivo são: São Paulo e Rio de Janeiro, devido a essas 2 cidades abrigarem várias sedes de empresas. Entretanto esse fato não foi constado como regra pelas outras 13 empresas questionadas. 
Ainda de acordo com o gráfico acima e sendo reiterado por um dos representantes da AMPRO em entrevista no dia 19/05/2009, pode-se analisar que as cidades históricas de Minas Gerais vêm ganhando espaço nesse mercado.

Para a Confederação Brasileira de Conventions \& Visitors Bureaux, essa diversidade da oferta brasileira é muito favorável para a apresentação do país no exterior como destino de incentivo.

Em combinação ou isoladamente, esses destinos nada deixam a desejar quando comparados aos mais concorridos lugares do mundo, segundo os representantes da AMPRO. Pois, para eles, o Brasil oferece grandes companhias aéreas, rede hoteleira com a presença das maiores bandeiras internacionais, boa infra-estrutura para eventos, além de diversidade de destinos e de lazer.

Eles ainda destacaram que existem alguns produtos que funcionam como bons catalisadores de viagens de incentivo como a Fórmula 1, o carnaval do Rio, da Bahia, de Recife e de São Paulo, a grande diversidade de feiras e eventos segmentados, e ainda significante quantidade de empresas com sede em outros países.

O representante da área de Segmentação do Ministério do Turismo, apresentou em sua entrevista que a cidade de Ribeirão Preto -SP, vem desenvolvendo um trabalho de turismo de incentivo e eventos. Devido a este fato, esta cidade foi escolhida pelo Ministério do Turismo como Destino Referência de Turismo de Negócios e Eventos no Brasil. Ele ainda explica que neste caso, o apelo de incentivo de Ribeirão Preto é a agroindústria, além da produção de etanol. A cidade utiliza-se do título de "A Capital do Etanol" para atrair turistas de negócios e incentivos.

Os dados evidenciam que o país possui bons produtos a serem trabalhados como destino de incentivo, basta os operadores usarem a criatividade e a ousadia.

\subsubsection{Mercados Emissivos}

Segundo a pesquisa aplicada em 2006 que se encontra no Anexo A, os principais mercados emissivos de viagens de incentivo para o Brasil são Inglaterra, Itália e França.

Apesar de os turistas dos Estados Unidos possuírem empecilhos diplomáticos como 
vistos de entrada no Brasil, deste país também se origina significativa demanda para o segmento de incentivo brasileiro.

Esses dados coincidem com os apresentados por Elisete Hoeller (1999) no item "Principais Emissivos", no qual se explica que esse feito se deve a grande quantidade de multinacionais existentes nesses países.

\subsubsection{Políticas Públicas}

Os representantes do Ministério do Turismo e da CBCVB afirmaram não figurar em seus planejamentos, estratégias para o turismo de incentivo. Apenas as representantes do Embratur, mencionaram que aquela autarquia está em fase de planejamento do segmento, o que já é avanço para os órgãos públicos, pois o primeiro passo para o desenvolvimento deste segmento já foi dado, que é o reconhecimento.

\subsubsection{Vocação Brasileira para o Segmento}

Por meio das entrevistas contatou-se que a imagem do Brasil como destino de Incentivo deve estar voltada à grande diversidade cultural e natural que este país oferece.

Pois, ao ser questionado sobre esse tema, o representante da Gerência de Estruturação de Produtos do Embratur, disse acreditar que:

“(...) a vocação é significativa, pela diversidade de experiências possíveis de serem vivenciadas no Brasil. Entretanto, tenho dúvidas quanto ao nível de qualidade e criatividade dos serviços ofertados pelas empresas do ramo."

Já o representante da Gerência de Congressos, Negócios e Incentivos do mesmo Instituto, aposta nas idéias dos profissionais de incentivo brasileiros e afirma que o que precisa mudar no país são as atitudes tomadas frente aos patrimônios. Assim como podem ocorrer eventos, jantares, etc no Museu do Louvre, ele afirma que o mesmo deveria acontecer em nossos museus e palácios.

A CBCVB, e os representantes do Ministério do Turismo concordaram com o Embratur no quesito diversidade brasileira. 
Dentre essa diversidade a Gerencia de Segmentação do Mtur ressalta a variedade de sabores, culturas, credos, que podem e devem figurar como produtos de incentivo.

A Diretoria de Marketing do mesmo Ministério, e os representantes da AMPRO compartilham da opinião que a imagem e os produtos da diversidade brasileira já estão estruturados. Sendo necessário apenas a sua formatação e comercialização.

O Comitê de Operadoras de Incentivos, diz que o Brasil possui todos os prérequisitos para ser um destino de incentivo de excelência, pois por ser "bom para o negócio, é bom para o ócio".

O representante desse Comitê ainda cita o fato de o Brasil ser sede na América Latina de diversas multinacionais como a Bayer, a Microsoft, a GE, Coca-Cola, Nestlé, Unilever, Toyota, dentre outras.

Apesar dessas opiniões, sugere-se que seja realizada uma pesquisa a fim de identificar como o Brasil se projeta para o trade internacional no segmento de viagens de incentivo. 


\section{CONCLUSÃO}

Esta pesquisa teve como objetivo geral analisar o Brasil como destino de incentivo e por fim constatou que este é um mercado promissor que deve ser melhor trabalhado no país. Pois aqui existem potencialidades ímpares como o ineditismo, boa infraestrutura turística, além de fortes apelos culturais e naturais como as suas festas populares e as dezenas de florestas, o que segundo a bibliografia analisada e os entrevistados, são requisitos importantes para o segmento.

Ao se analisar o panorama do Turismo de Incentivo no país, pode-se afirmar a inexistência de políticas públicas de apoio ao segmento no Brasil. Ademais a oferta de viagens de incentivo pelo trade está descentralizada, havendo várias organizações totalmente turísticas ou não, relacionadas ao mesmo (tais como AMPRO, FAVECC, ABGEV, BITO), sendo que não se identifica liderança de uma sobre as demais.

.Apesar dessa descentralização, aqui figuram excepcionais equipamentos que poderiam ser utilizados pelo turismo de incentivo, tais como museus, monumentos históricos, parques, festas populares. No entanto, a falta de cultura na exploração destes espaços para realização de eventos e atividades de incentivo impede que os agentes turísticos possam utilizá-los em sua total potencialidade.

Já outros destinos como Cape Town e Melbourne estão cada vez mais empenhados em se firmarem como destino de viagens de incentivo, figurando em seus planejamentos governamentais ações específicas para o segmento.

Por meio da análise das entrevistas com o trade turístico brasileiro, chegou-se à conclusão que a vocação do Brasil como destino de Incentivo está em explorar a sua diversidade. Diversidade essa que é climática, regional, gastronômica, geográfica, e cultural.

Para tanto, sugere-se no tópico seguinte algumas ações. 


\section{CONSIDERAÇÕES FINAIS}

Frente ao cenário do Turismo de Incentivo brasileiro apresentado acima, faz-se necessário um planejamento urgente desse segmento, que deve reunir todos os atores envolvidos bem como os setores públicos e privados, pois com a proximidade da Copa do Mundo de 21014, de acordo com as experiências relatadas por países que sediaram outras edições da Copa do Mundo da FIFA, o crescimento das atividades de turismo de incentivo nos períodos pré e trans-evento constituem-se em um dos maiores benefícios gerados com a captação do evento.

Sugere-se, seguindo o modelo de Cape Town, que a pedra fundamental deste planejamento seja uma profunda pesquisa da situação atual deste segmento no Brasil para que se conheça a oferta de produtos, e quem seriam os potencias consumidores dos mesmos.

A articulação entre o trade de incentivo brasileiro e órgãos governamentais também se faz necessária, a fim de se implementar um Bureau de Incentivo, o qual constituirá em uma liderança para o segmento.

Este bureau deverá realizar reuniões regulares com os seus membros e com a iniciativa pública para traçar o Plano Estratégico de Turismo de Incentivo. Este plano terá como objetivo primeiro definir qual a imagem (vocação) do Brasil como destino de incentivo a ser utilizada. Ou seja, qual será o apelo brasileiro para atrair viagens de incentivos. O presente trabalho permitiu concluir que de acordo com os entrevistados essa vocação tende para a Diversidade Brasileira.

Para a criação deste Plano Estratégico poderiam ser realizados benchmarkings a países de referência em incentivos como Estados Unidos, Austrália, Nova Zelândia e África do Sul.

Conforme também sugerido por representantes da AMPRO, faz-se necessária a capacitação dos atores públicos e privados do segmento, para que assim se tenha uma mão de obra especializada. Esta capacitação poderia acontecer em forma de workshops, palestras e treinamentos. 
Após devidamente estruturado o segmento, aconselha-se a sua divulgação no exterior através de famtrips, publicidade em mídia especializada, relacionamento com grandes empresas que se utilizam de programas de incentivos, participação em eventos (feiras) do segmento, etc. 


\section{REFERÊNCIAS}

\subsection{Bibliográficas}

AMARAL, Karla J. Segmentação do mercado turístico: bases, tipologias e tendências: CEPEX EM REVISTA. Itararé, ano 01. N. 01. Abr/Mai/Jun. 2005 ANSARAH, Marília G. R. (org.) Turismo - Segmentação de Mercado. São Paulo: Futura, 1999.

ARRILLAGA, J.I, Introdução ao estudo do Turismo, Rio de Janeiro, Ed. Rio, 1976.

BARRETTO, Margarita. Manual de Iniciações ao Estudo do Turismo. Ed.9 Campinas: Papirus, 1999

BARRETTO, Margarita. O imprescindível aporte das ciências sociais para o planejamento e a compreensão do turismo. Horizontes Antropológicos, Porto Alegre, ano 9, n.20, p. 15-20, outubro de 2003.

BENI, Mário Carlos. Análise estrutural do turismo. 7 ed. São Paulo: SENAC São Paulo, 2002.

BERVIAN, Pedro A., CERVO, Amado L. Metodologia Científica. São Paulo: Prentice Hall, 2002

COBRA, Marcos Henrique Nogueira. Marketing básico: uma perspectiva brasileira . 4 ed. São Paulo: Atlas, 1997

CRESCITELLI, Edson. Marketing de Incentivo, São Paulo: Cobra, 2002.

CUNHA, Licínio. Economia e Política do Turismo. Lisboa: McGRAW-HILL, 1997

DIAS, Reinaldo; AGUIAR, Marina Rodrigues de. Fundamentos do Turismo: conceitos, normas e definições. São Paulo: Alínea, 2002.

FILHO, Domingos P., SANTOS, João A. Metodologia Científica. São Paulo: Futura, 1998 ou 2003.

GODIM, Sonia M. G.; SILVA, Narbal. Motivação no Trabalho in ZANELLI, José C.; BORGES-ANDRADE, Jairo E.; BASTOS, Antonio V. B. Psicologia, Organização e Trabalho no Brasil. Porto Alegre: Artmed, 2004

HERZBERG,F. Como se faz para motivar um funcionário. in Biblioteca Harvard de Administração. São Paulo: Abril. 1975.

HOELLER, Elisete. Turismo de Incentivos. In: ANSARAH, Marília G. R. (org.) Turismo - Segmentação de Mercado. São Paulo: Futura, 1999.

HUNZIKER, W. \& KRAPF, K. Algmeine Frendenverkrslehre. Zurique, [s.n], 1942.

IGNARRA, Luiz Renato. Fundamentos do turismo. São Paulo: Pioneira, 1998.

JAFARI, J. (1989), Sctructure of Tourism. In: WITT, S.; MOUTINHO, L (eds.). 
Tourism Marketing and Management Handbook. Prentice Hall International: Reino Unido, 1989.

LEITE, Rogério C. de Cerqueira. Viagens do Homem que Atravessam os Séculos. Folha de São Paulo, São Paulo, 21/02/1991.

MARCONI, Marina A.; LAKATOS, Eva M. Técnicas de Pesquisa. 7 ed. São Paulo: Atlas, 2008.

MARTIN, Vanessa, Turismo de Incentivo: eventos e viagens como premiação no Brasil. Dissertação de Mestrado, Departamento de Comunicação e Artes da Escola de Comunicações e Artes da USP, 2006

MASLOW, A. Motivação e Personalidade. Nova lorque: Harper\& Row, 1954.

MOESCH, Marutschka Martini. A Produção do Saber Turístico. São Paulo: Contexto, 2004.

MORAES, Claudia Corrêa de Almeida. Turismo-segmentação de mercado: um estudo introdutório. In: ANSARAH, Marilia G.R.(org.)Turismo: segmentação de mercado. São Paulo: Futura, 1999

O ESTADO DE SÃO PAULO; In: ANSARAH, Marília G. R. (org.) Turismo - Segmentação de Mercado. São Paulo: Futura, 1999.

ONU, 1979. In: DIAS, Reinaldo; AGUIAR, Marina Rodrigues de. Fundamentos do Turismo: conceitos, normas e definições. São Paulo: Alínea, 2002.

PIMENTA C.; RICHERS R., Segmentação: opção estratégica para o mercado brasileiro. São Paulo: Nobel, 1991.

PINTO, Ivan. Segmentação do mercado: uma oportunidade incompreendida. I Debate de Marketing publicado na Revista Mercado Global, v. 8, n. 46, 1980, p. 3241.

PIRES, Luciano David. A Nova Fase do Turismo Mundial; Rio de Janeiro: Eu \& Você, 1983

RICCI, Peter, HOLLAND, Stephen M., Incentive: recreation as a motivation medium. Tourism Management, UK, v 13, n 13, setembro 1992.

ROSS, Glenn F. Psicologia do Turismo. São Paulo: Contexto, 2002.

SOUZA, Helena. Turismo de Incentivo: emoção, superação e profissionalismo. Matéria publicada na Revista dos Eventos - Edição nº 31 - 2004 - Pgs. 23-27

TORRES, Silvana. Marketing de Incentivos. Ed. Atlas, 2000

VAZ, Gil Nuno. Marketing Turístico: Receptivo e Emissivo. São Paulo: Pioneira, 1999.

WAHAB,Salah-Eldin Abdel. Introdução à administração do turismo. $3^{\circ}$ ed. São

Paulo: Pioneira, 1991. 


\subsection{Eletrônicas}

ABC Fly - Viagens e Incentivos. Disponível em http://www.abcflyviagens.com.br/corpora.htm> Acesso em 05/07/2009.

AMPRO. Disponível em:<www.ampro.com.br> . Acesso em 25 /04/ 2009.

AMPRO. Manual de Viagens de Incentivo. Disponível em $<$ http://www.ampro.com.br/servicos/recomendacoes/manual_ampro.pdf $>$ Acesso em 05/07/2009.

BARONE, Camila. Programas de incentivos. Disponível em: <http://carreiras.empregos.com.br/comunidades/rh/fique_por_dentro/251103pn_festas_fim_ano2.shtm>. Acesso em: $06 / 01 / 2009$.

BARINI, Camila. Marketing de Incentivo tem Movimento Crescente no Brasil. Disponível em: <http://www.tudocom.com.br/ci tudocom/materia/titulo/marketing-deincentivo-tem-movimento-crescente-no-brasil> Acesso em 13/06/2009

BRASIL. Ministério das Relações Exteriores. Definições. Disponível em:< http://www.mre.gov.br>. Acesso em: 10 de fevereiro de 2008.

BRASIL. Ministério do Turismo. Marcos Conceituais. Disponível em: <www.turismo.gov.br> . Acesso em 26/04/ 2009.

BRASIL. Ministério do Turismo. Plano Nacional do Turismo. Disponível em: <www.turismo.gov.br> . Acesso em 26/04/ 2009.

CALVO, Fabrina. Turismo de Incentivo: estimulando o desempenho de colaboradores nas empresas. 2006. Disponível em < www.artigos.com $>$, Acesso em 16/05/2009.

CAPE TOWN TOURISM, The Western Cape incentive sector. 2006. Disponível em < http://www.tourismcapetown.co.za> Acesso em 16/06/2009.

COSMOCRONOS. Disponível em< www.cosmocronos.blogspot.com $>$ Acesso em 05/05/2009.

EMBRATUR. Plano Aquarela. Disponível em: $<$ www.brasilnetwork.tur.br $>$. Acesso em 26/04/2009.

FAVECC, Disponível em <http://www.favecc.com.br/?url=perfildofavecc $>$ acesso em 8/06/2009.

FBCVB. Manual de Apoio. Disponível em:

$<$ http://www.fbcvb.org.br/hotsite/inscricao/manual_de_apoio.asp $>$ acesso em 08/06/2009. 
GOLRH. Cresce o número de empresas que premiam funcionários com viagens. Agosto de 2003. Disponível em < http://www.grupolabor.com/rhnot3.asp >, acesso em 25/05/2009.

IBOPE. Pesquisas. Disponível em $<$ http://www.ibope.com.br/calandraWeb/BDarquivos/sobre_pesquisas/tipos pesquisa .html> acesso em 09/06/2009.

MELBOURNE CONVENTION \& VISITORS BUREAU. Melbourne Incentives. Disponível em < www.mcvb.com.au>, acesso em 16/06/2009

MESQUITA, Westerlei S.Turismo de Incentivo: uma síntese mercadológica. 2006. Disponível em:< http://www.etur.com.br/conteudocompleto.asp?IDConteudo=11033> Acesso em 16/05/2009

OMT. Visão 2020. 2001. Disponível em: <http://www.unwto.org/>, Acesso em $15 / 06 / 2009$

RAMIRO, Denise. Turismo de Gravata. Revista Isto É. 24 de maio de 2006. Disponível em: <http://www.terra.com.br/istoedinheiro/453/negocios/turista_gravata.htm>. Acesso em: 6 de janeiro de 2009.

SITE. Disponível em <http://www.siteglobal.com/About/Vision/tabid/73/Default.aspx>, acesso em 08/06/2009.

TASSITANI, Cléo. Quanto custa uma viagem de Incentivo? Diponível em: $<$ http://www.destaquesp.com/index.php/Turismo/Especial/quanto-custa-uma-viagemde-incentivo.html >, acesso em 05/05/2009

TURISMO de Incentivo Cresce no Brasil. O Estadão, São Paulo, 26 de fevereiro de 2002, Disponível em <http://www.estadao.com.br/arquivo/suplementos/2002/not20020226p72133.htm>, acesso em 09/06/2009.

WERZBITZKI, João José. Turista de eventos gasta US\$314,70 por dia, no Brasil. Disponível em <http://blogs.abril.com.br/blogdojj/2009/05/turista-eventos-gasta-us314-70-por-dia-no-brasil.html> , acesso em 23/06/2009 


\section{APÊNDICES}

\section{Apêndice A: Gráficos da Pesquisa de 2006}

Esta pesquisa foi elaborada por esta pesquisadora em parceria com a acadêmica Shenia Patricia Cassiano de Oliveira, em 2006.

Foram questionadas, por email, as seguintes Agências de Viagens:

- Free Way Turismo;

- Best Team Brazil;

- Elcotur;

- Havas Creative Tours;

- Contempory Travel;

- OPCO Tours;

- Del Bianco;

- Blumar;

- Clássico Turismo;

- Ambiental Expedições Viagens e Turismo;

- Sobratur;

- Tropical Secrets;

- Incentivare;

- Rentamar Turismo.

Os dados tabulados desta pesquisa seguem: 


\section{O que diferencia uma viagem normal de uma viagem de incentivo?}

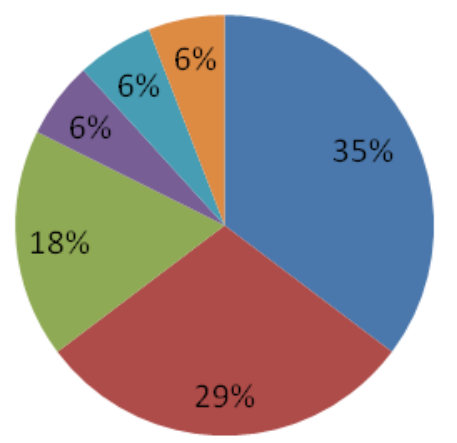

- programação

- patrocinio da empresa

- premiar

motivar

- perfil participantes

coutros

\section{Qual o público?}

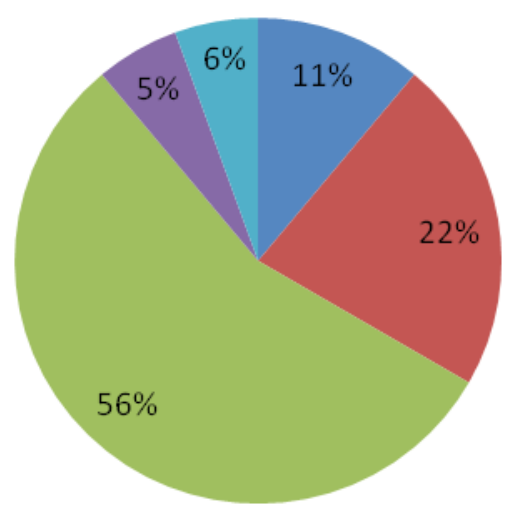

clientes/revendedores/co nvidados

—empresários em geral

funcionários de multinacionais

- funcionários com acompanhantes

autros

\section{Quais os destinos mais procurados?}

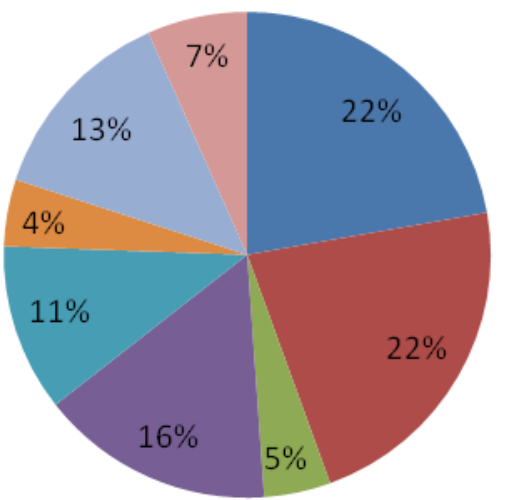

- RJ

- Salvador

$\square \mathrm{SP}$

- Foz do Iguaçu

nordeste

Bonito

- Manaus

- MG 
O que está incluído no pacote de viagem de incentivo?

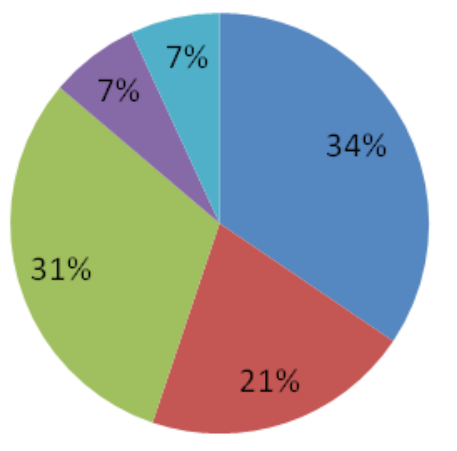

- hospedagem/transfer/city tour

- atividades diferenciadas

festas/shows

- palestras/dinâmicas

\section{Quantos dias duram uma viagem de} incentivo?

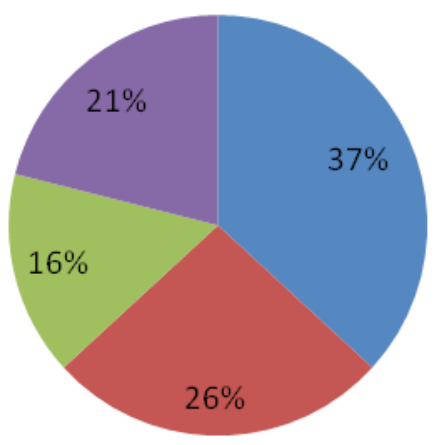

- 5 a 7

- 7 a 10

mais de 10

- 3 a 5 
Qual o mês de preferência para a realização dessas viagens?

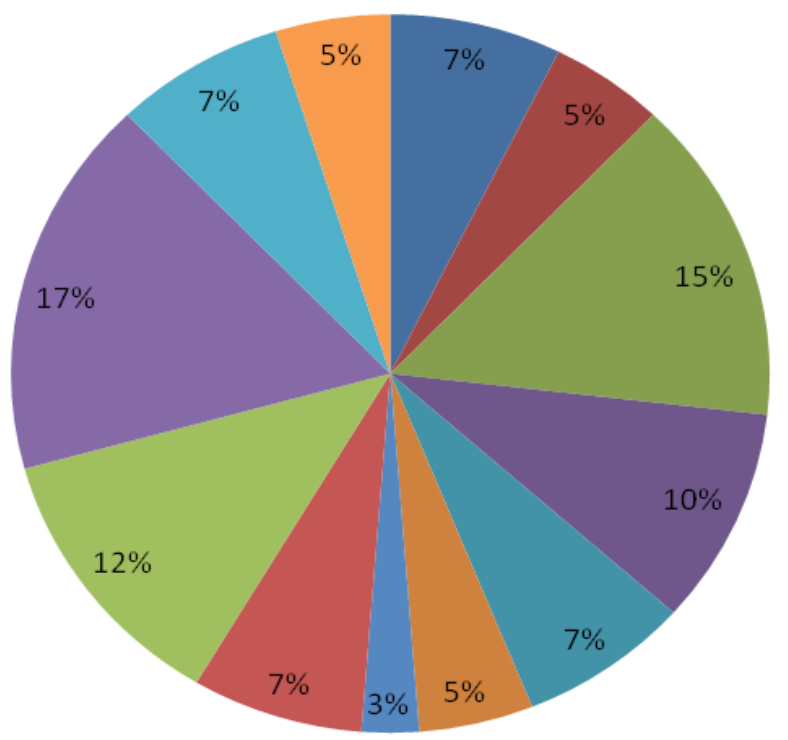

\section{Qual o meio de divulgação dos pacotes de incentivo?}

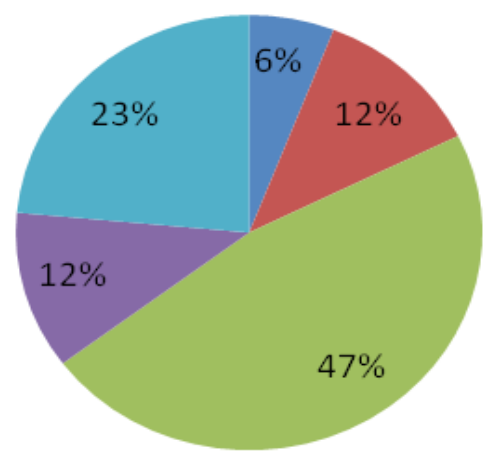

agências de viagens

— internet/publicações

- mediação feita por operadores no exterior

feiras

- outros 
Para realizar as viagens de incentivo, as empresas procuram as agências ou é o contrário?

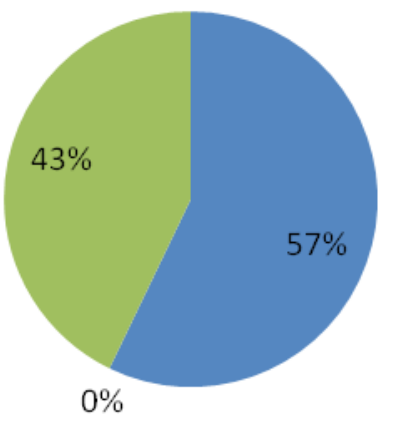

a empresa procurou a agência

- a agência procurou a empresa

ambos

\section{Qual o gasto médio do turista de incentivo por viagem?}

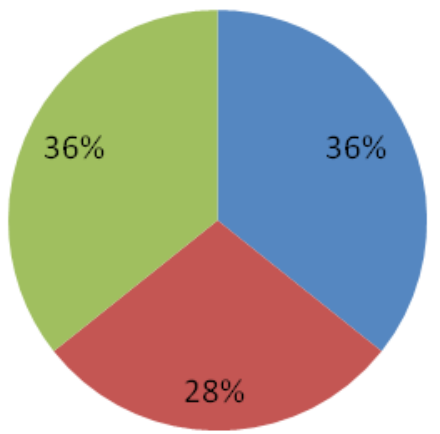

mais de 2 mil dólares

घ 1 mil a 2 mil dólares

- depende/não quis responder 


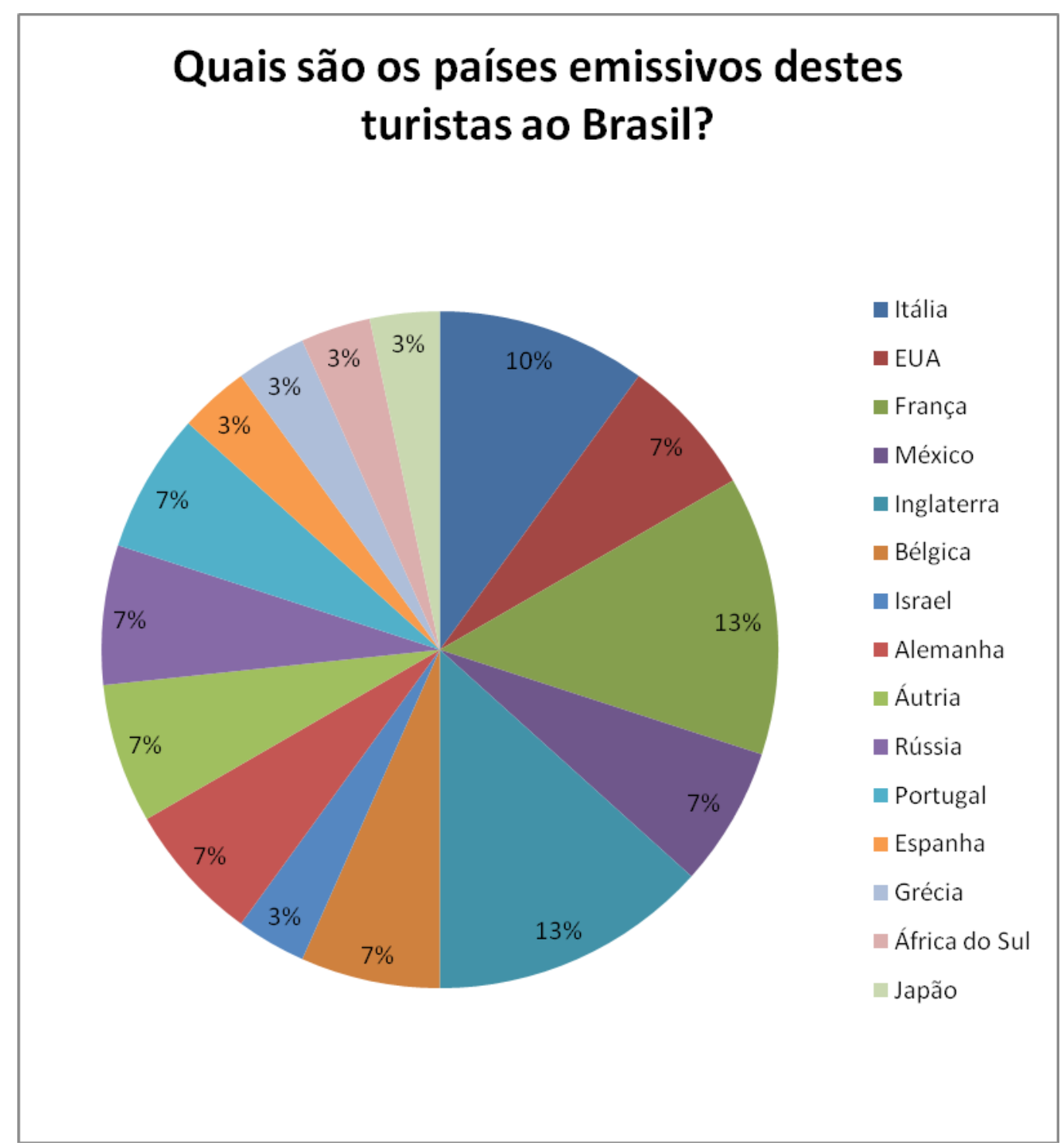




\section{Apêndice B: Roteiro de entrevista com órgãos públicos e associativos.}

Nome:

Empresa:

Data:

Na sua opinião:

1)O que diferencia uma viagem normal de uma viagem de incentivo?

2)O que deveria ser incluído nos pacotes das viagens de incentivo?

3) Você tem conhecimento de alguma estratégia de incentivo utilizadas por outros destinos? Destas estratégias, alguma se adéqua a realidade brasileira?

4) Você tem conhecimento de destinos brasileiros que são trabalhados como destino de incentivos? Se sim, quais? E quais produtos possuem potencialidade no segmento?

5)Como você acha que está organizada a oferta do produto de incentivos no Brasil?

6) Como o Brasil pode promover o segmento no exterior?

7) Na empresa que você trabalha, figura em seu planejamento o Turismo de Incentivos?

8) Se sim, você acha que essas ações são suficientes?

9) Por fim, qual é a vocação do Brasil para o segmento de viagens de incentivo? 


\section{ANEXOS}

\section{Anexo A: Apresentação AMPRO do dia 19/05/2009}
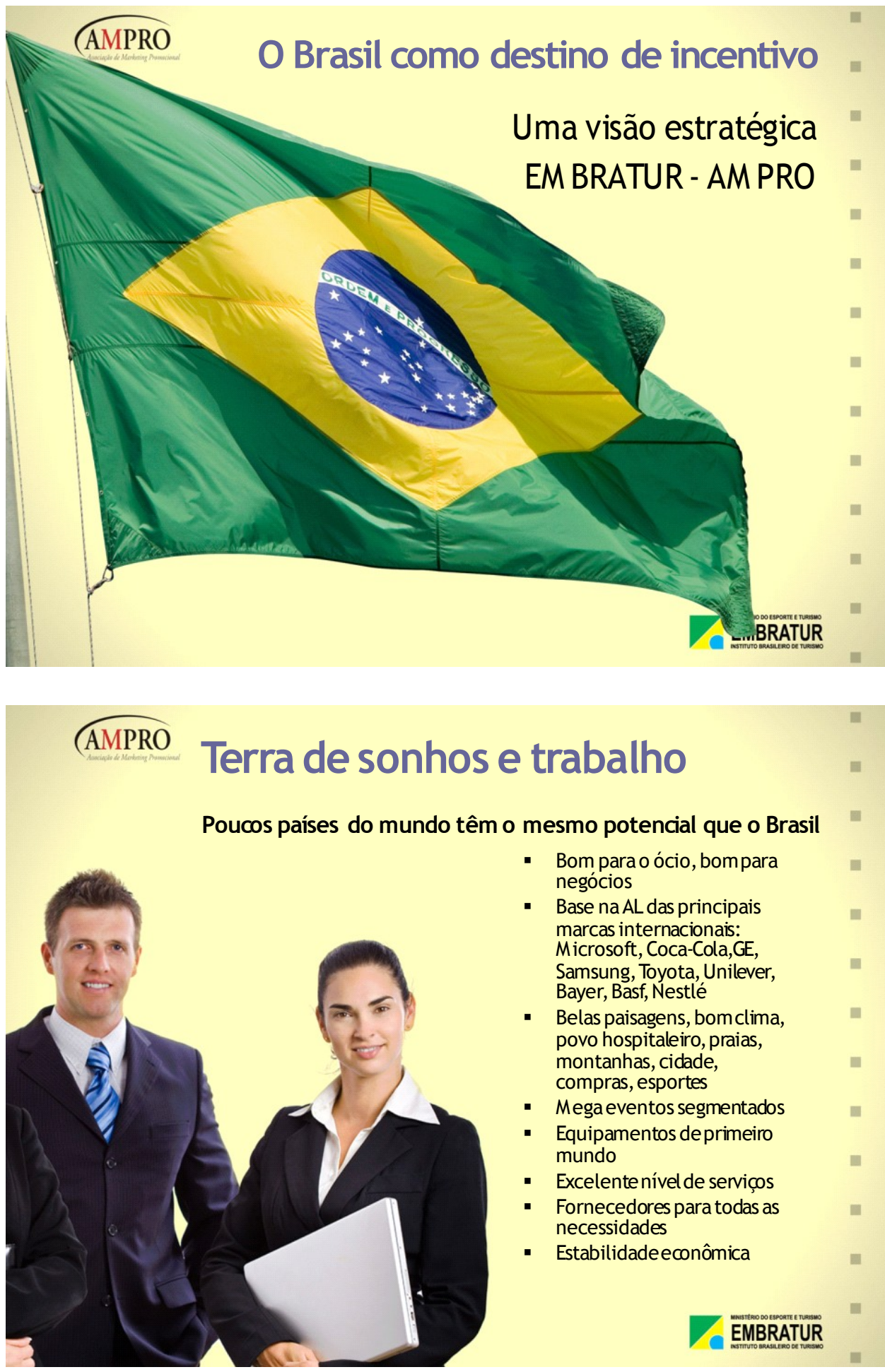

EMBRATUR

- Bom para o ócio, bompara negocios

- Base na AL das principais marcas internacionais: Microsoft, Coca-Cola,GE, Samsung, Toyota, Unilever, Bayer, Basf, Nestlé

- Belas paisagens, bomclima, povo hospitaleiro, praias, montanhas, cidade, compras, esportes

- Mega eventos segmentados

- Equipamentos deprimeiro mundo

- Excelentenível de serviços

- Fornecedores para todas as necessidades

- Estabilidadeeconômica 

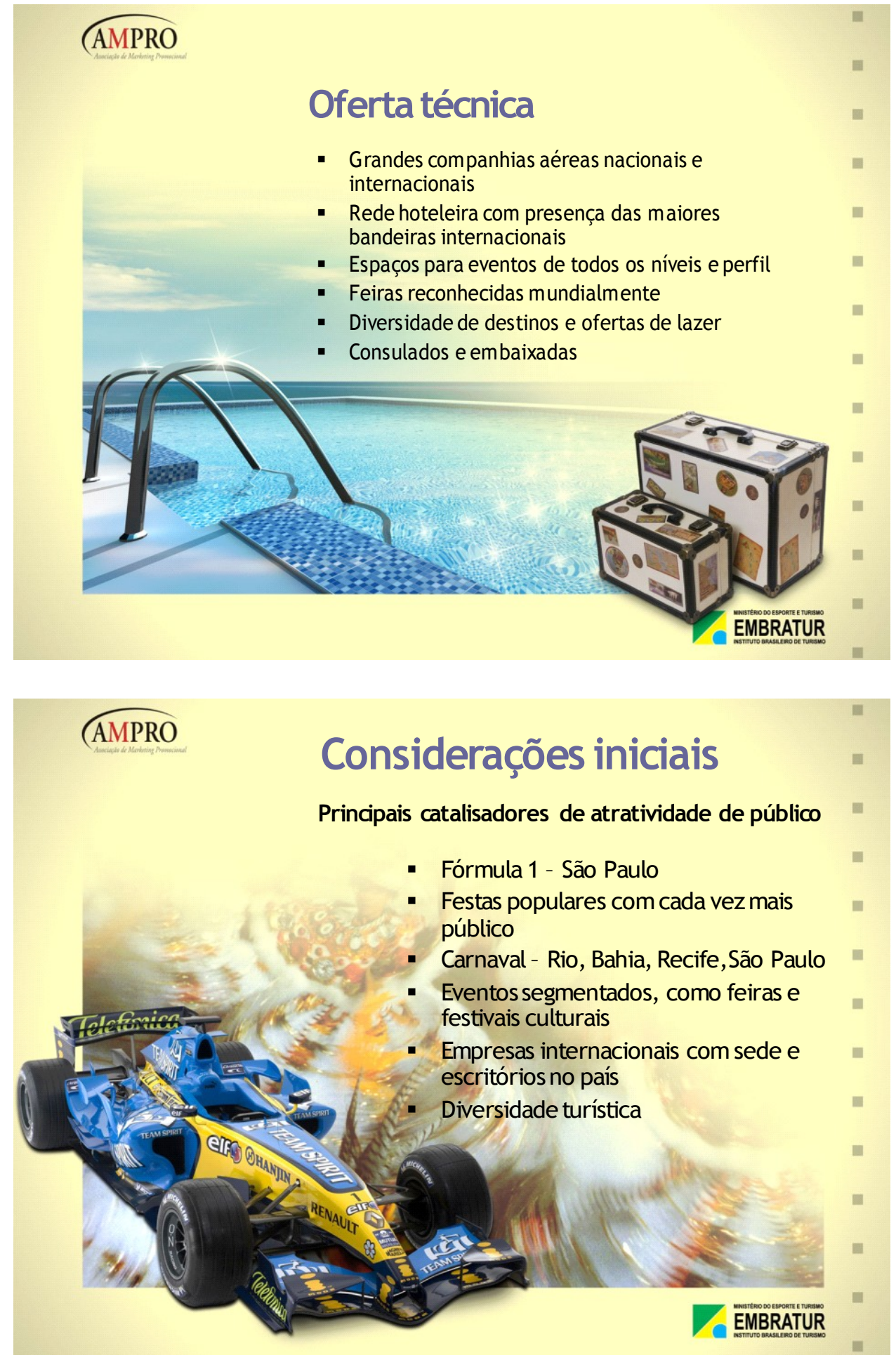

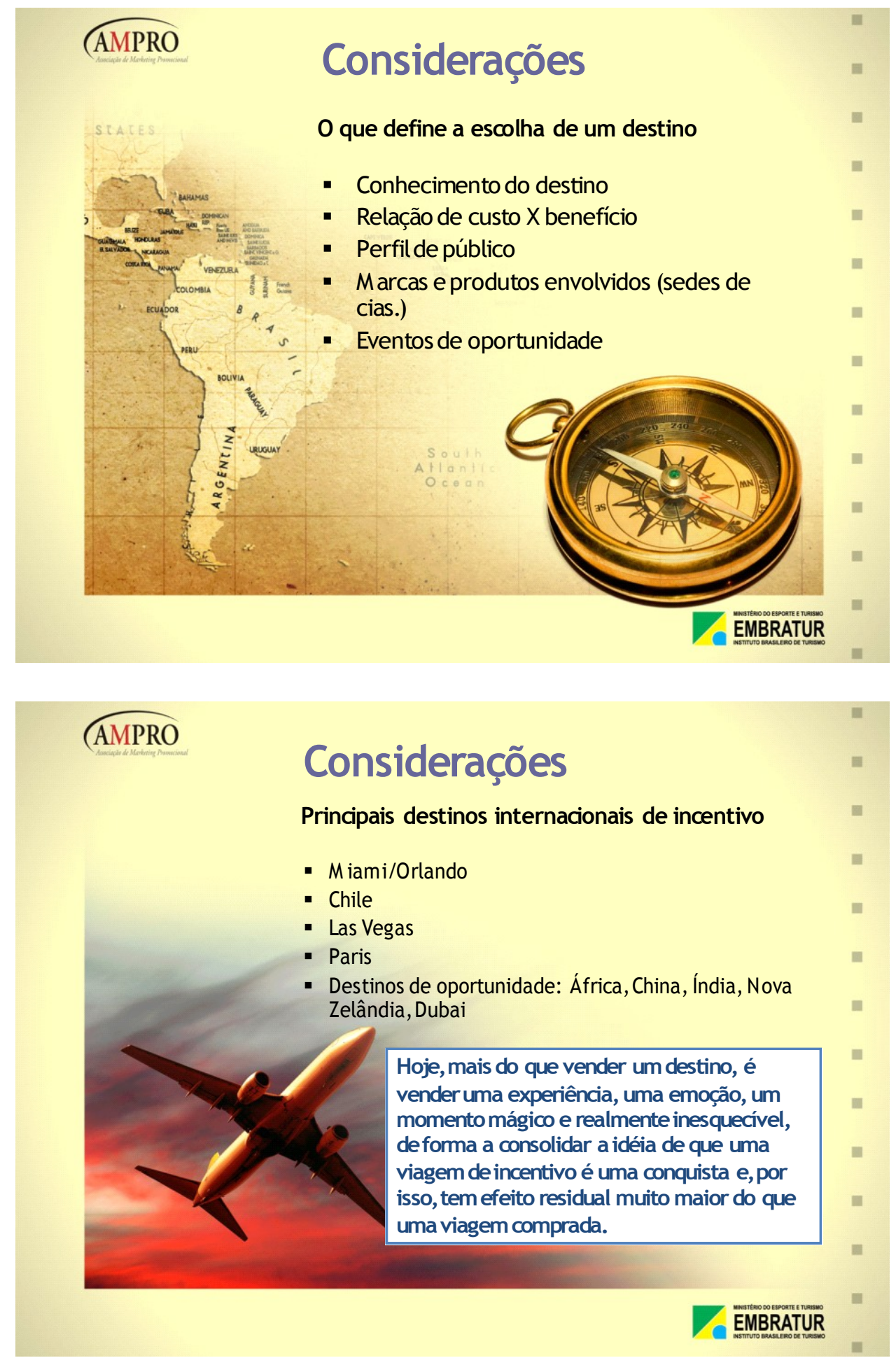

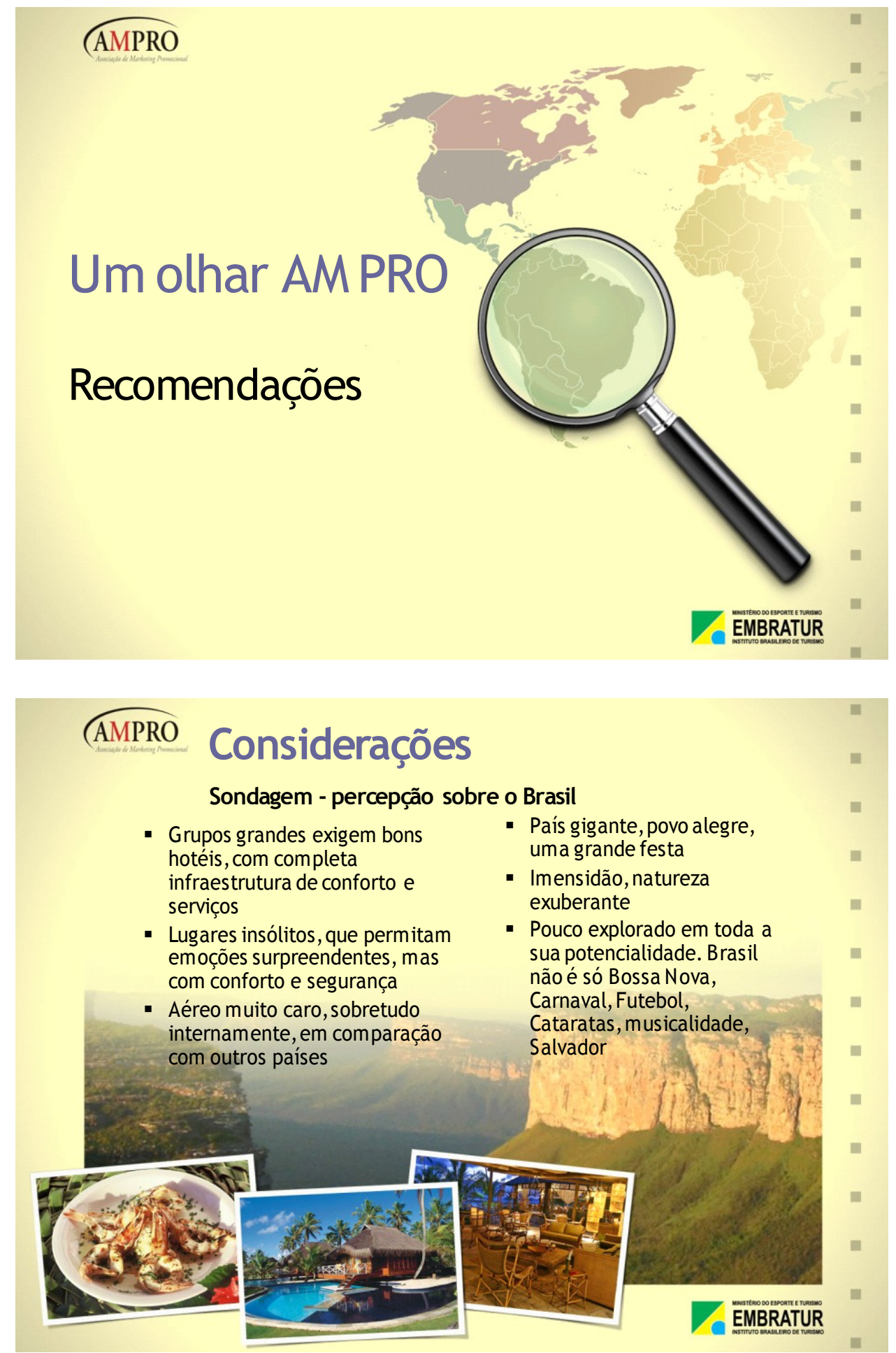

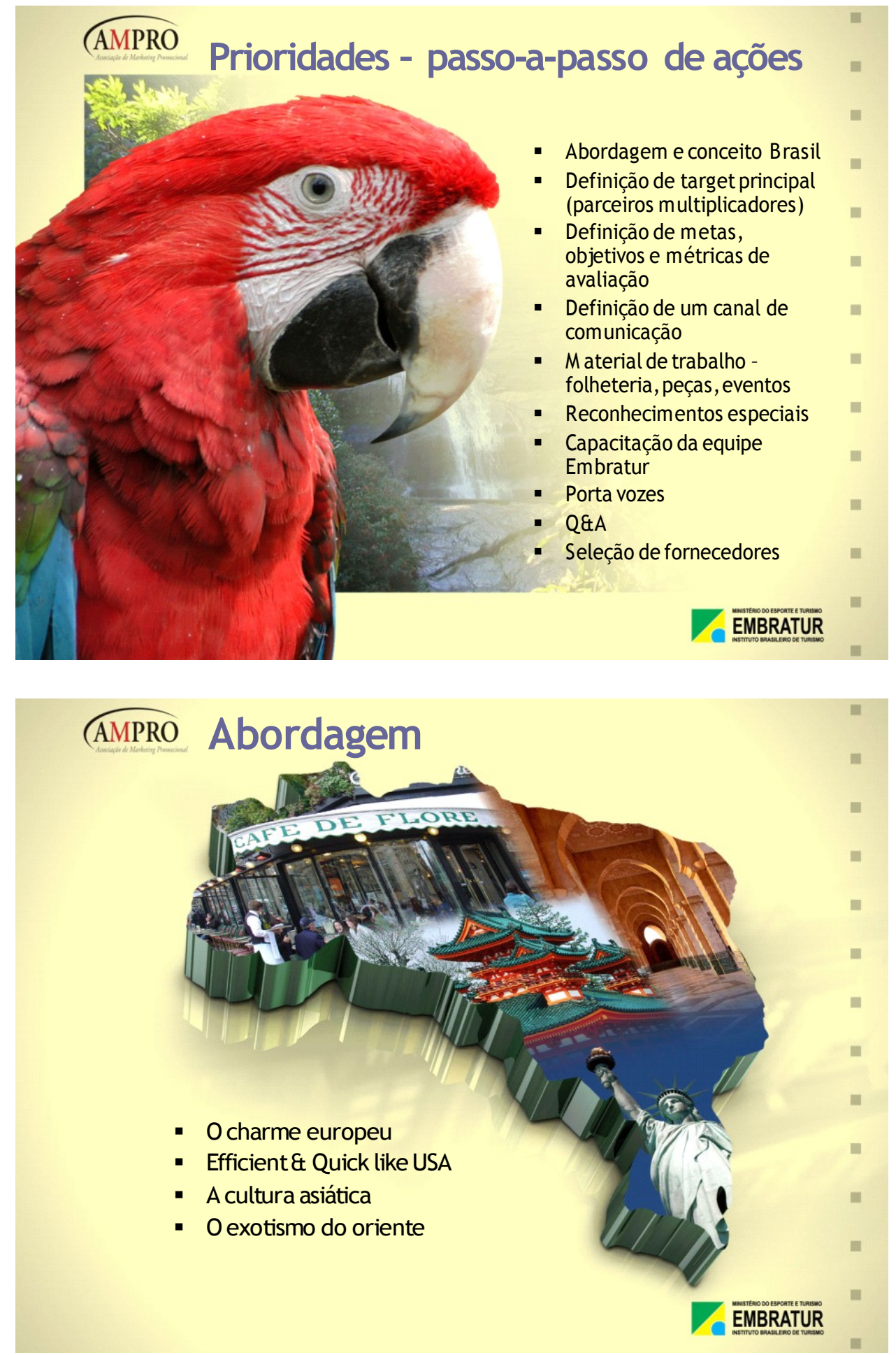


\section{АMPRO Conceito Criativo}

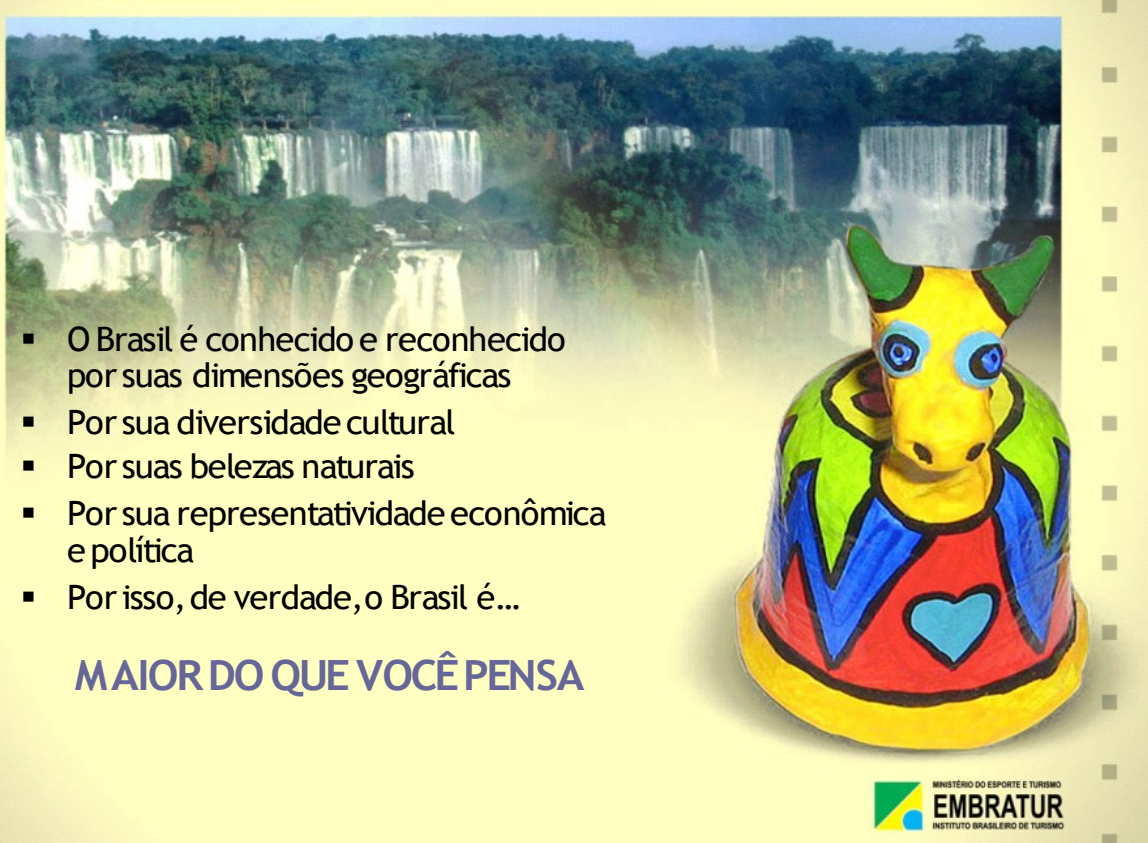

\section{AMPRO Justificativa do conceito}

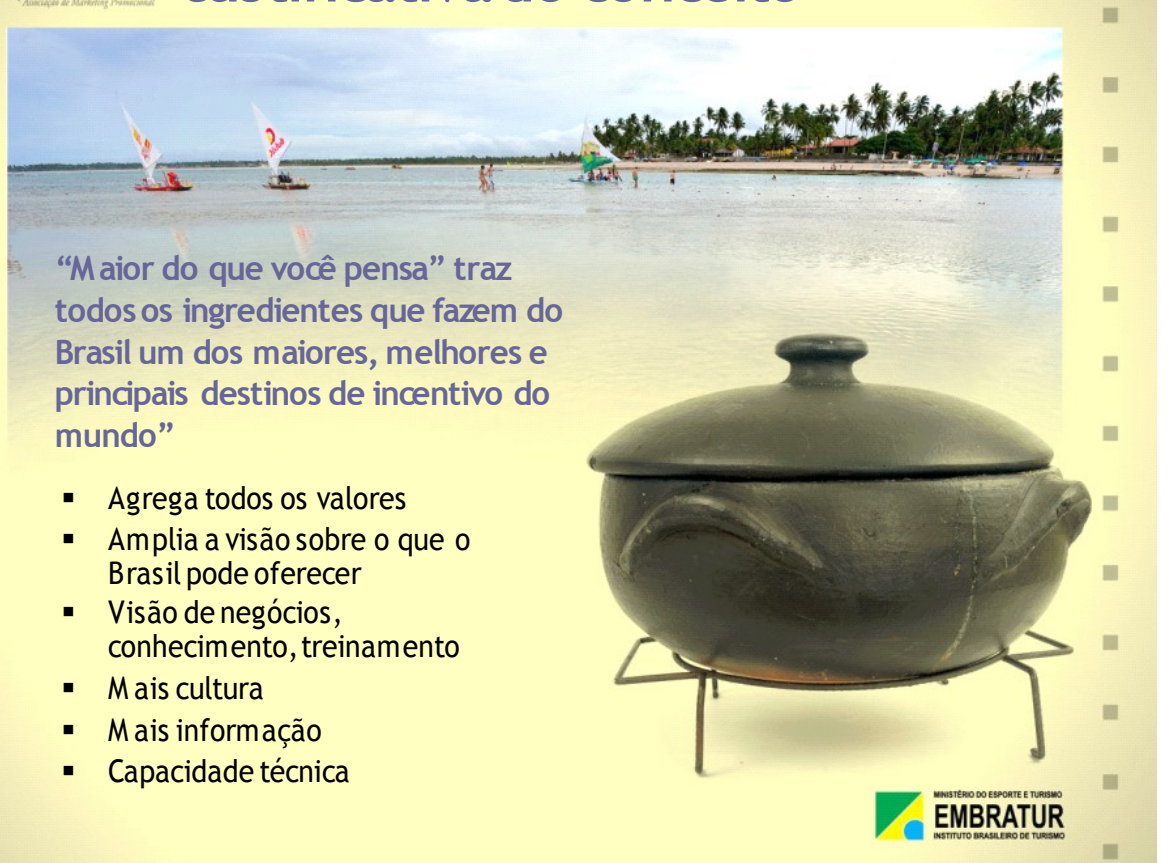




\section{AMPRO Estratégia de atuação}

AAM PRO vê 3 fases para um programa de parceria com a EM BRATUR

1. Capacitação M ICE (M eetings/ Incentives/ Congresses/ Exhibitions)

2. Programa de relacionamento/ ampliação de conhecimento com países-alvo

3. Programa de incentivo à ampliação de negócios com países-alvo

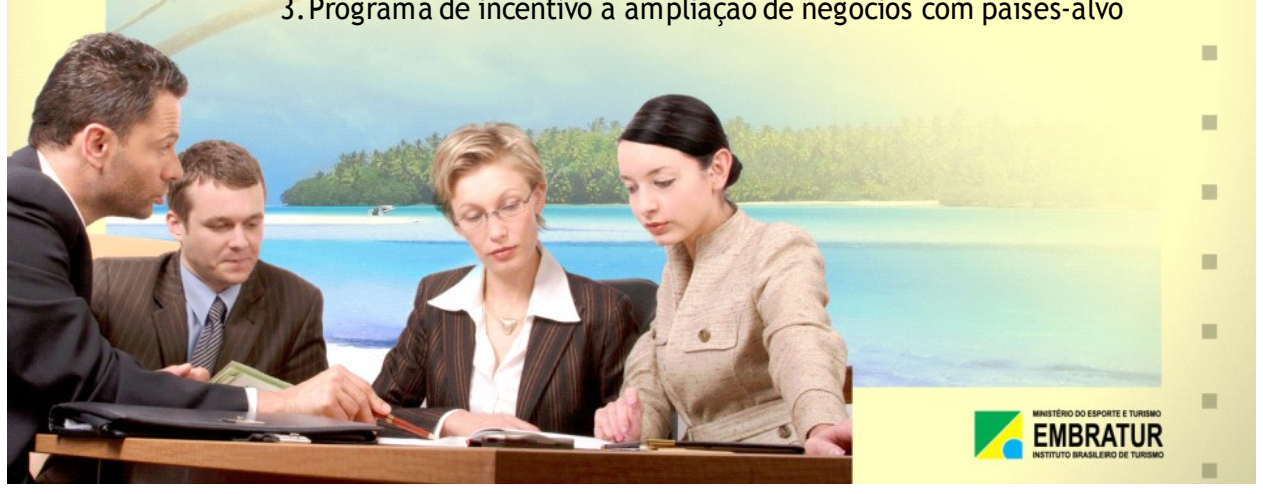

\section{AMPRO 1. Capacitação M ICE}

Programa liderado pela AMPRO visando capacitar pessoas-chave da EMBRATUR (Brasil e exterior), quanto aos fundamentos MICE, suas características e, técnicas de atração desse tipo de eventos parao Brasil.

-Workshops

- Palestras

-Treinamento

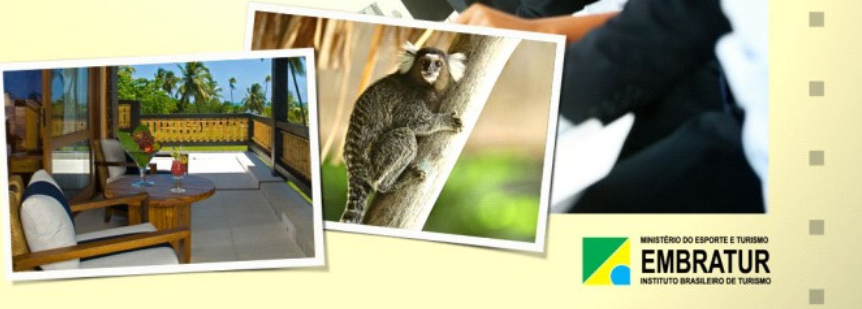




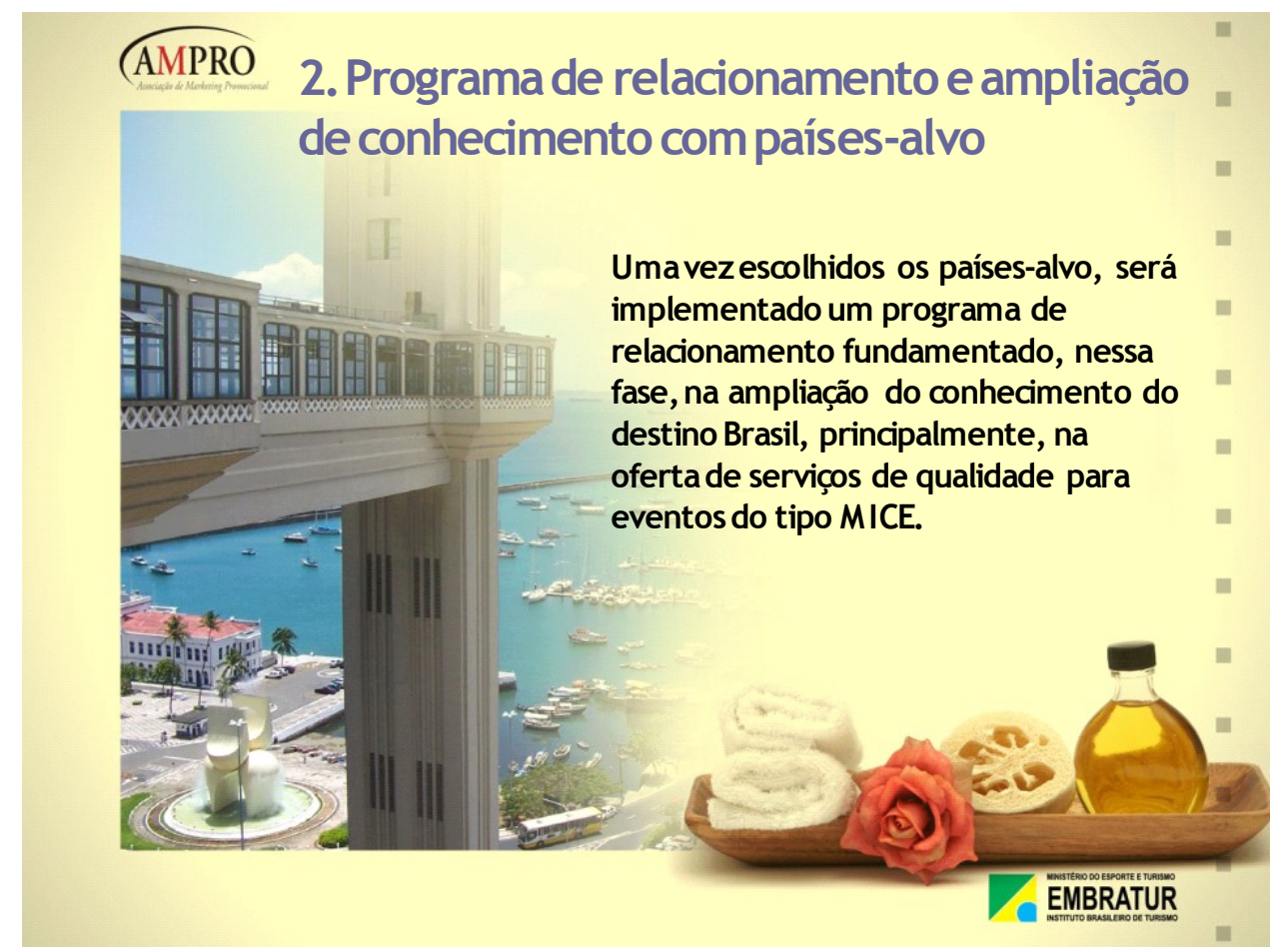

\section{AMPRO 2. Programa de relacionamento e ampliação de conhecimento com países-alvo}

As atividades compreenderão os seguintes pontos:

- Identificação dos target-groups principais (gestores de marketing e vendas de grandes empresas, agências especializadas em serviços de marketing, operadoras de outgoing especializadas em M ICE)

- Canais de comunicação (site, publicação especializada, blog)

- Desenvolvimento de instrumentos de comunicação (folheteria, kits, brindes)

- Criação e desenvolvimento do programa de relacionamento e motivação

- Premiação

- Road-shows, MICE FAM TRIP

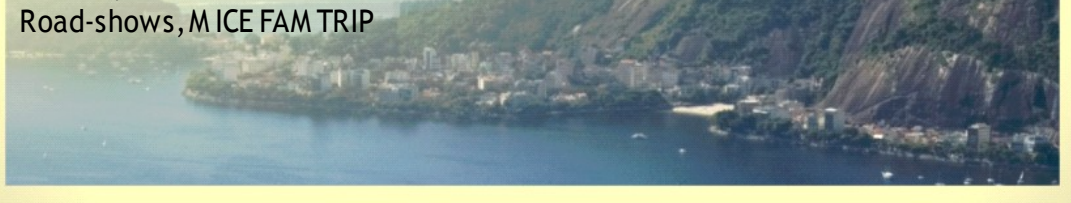




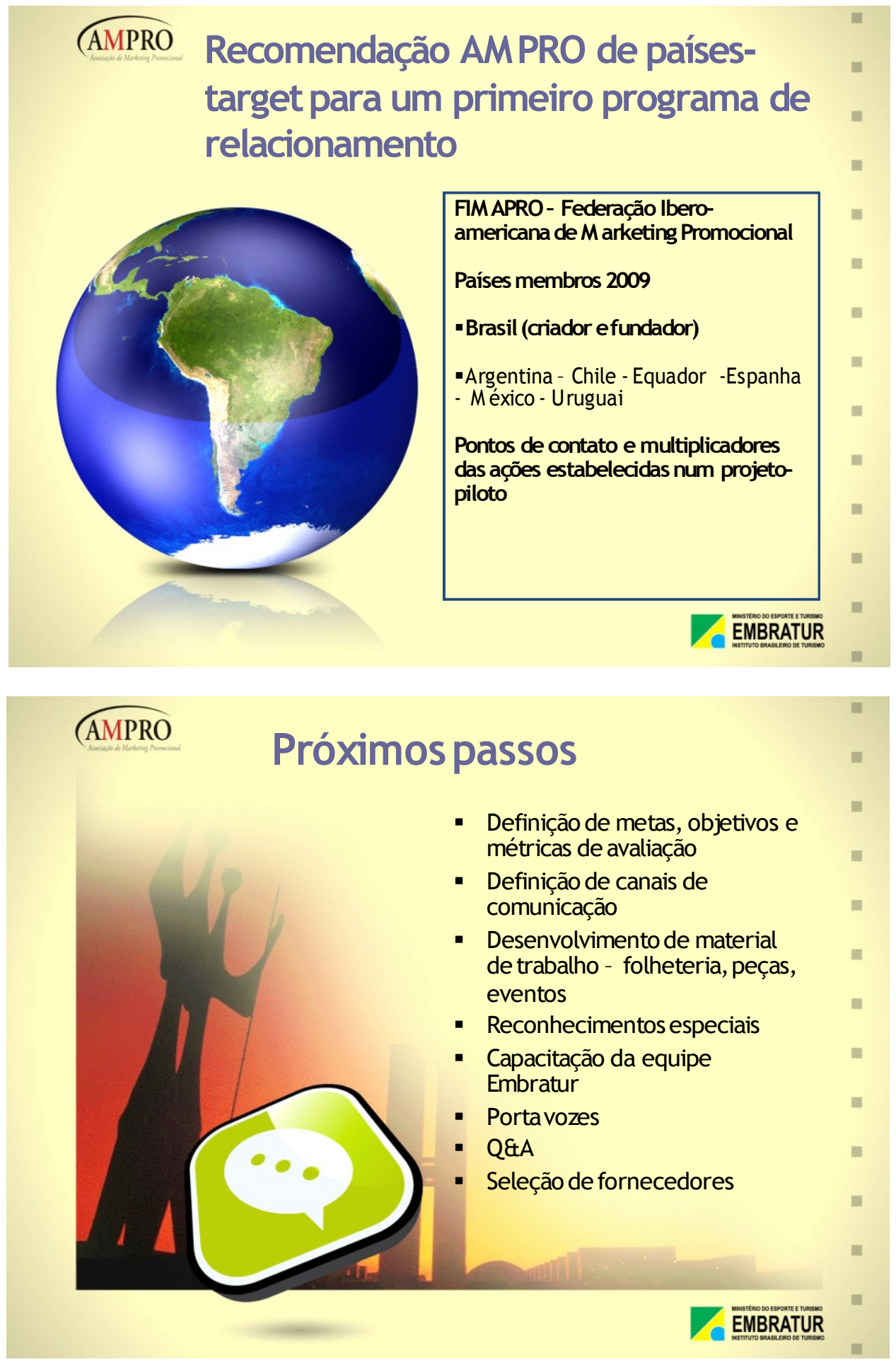



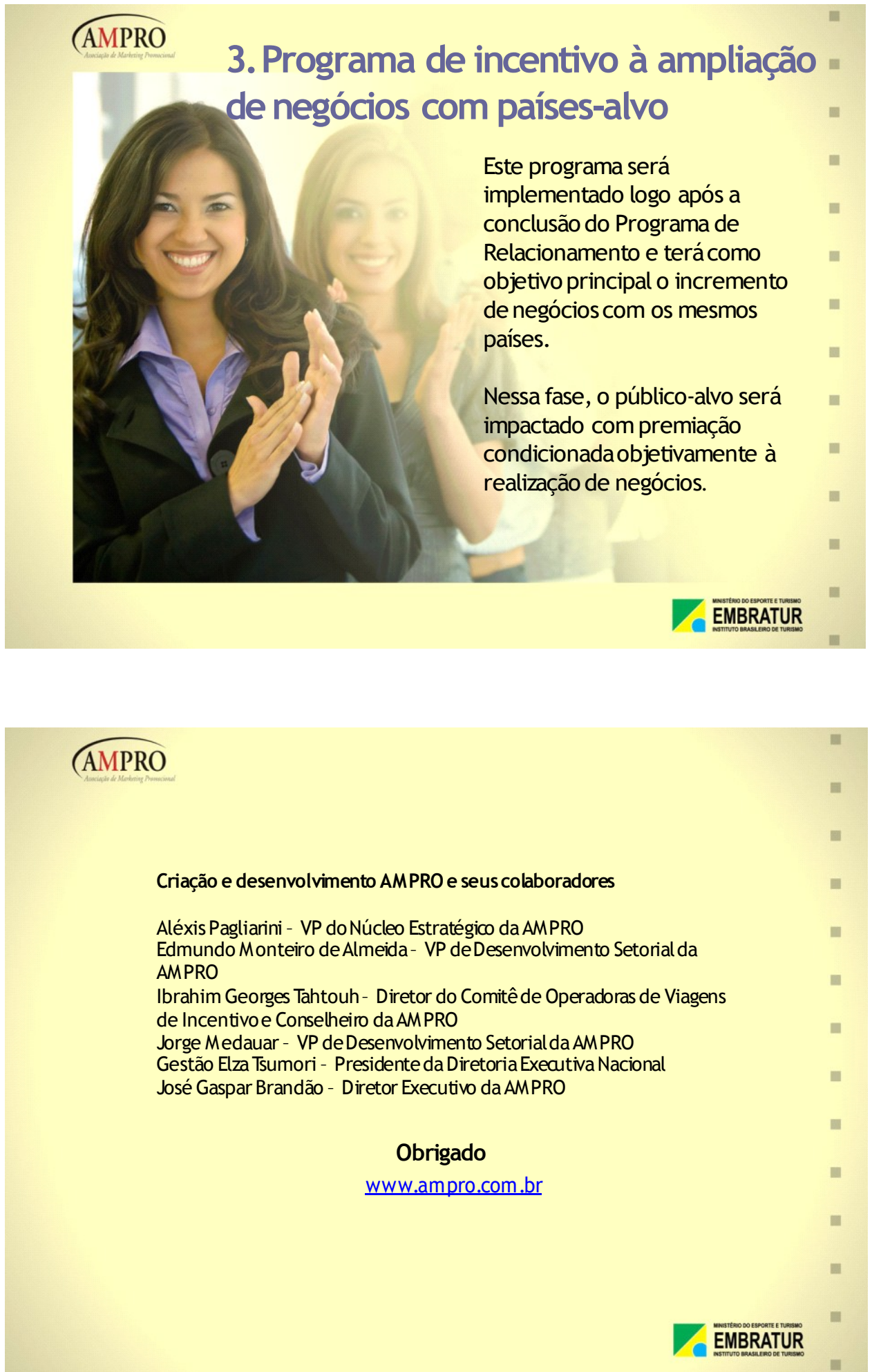


\section{Anexo B: Fotos com representantes da AMPRO no dia 19/05/2009}

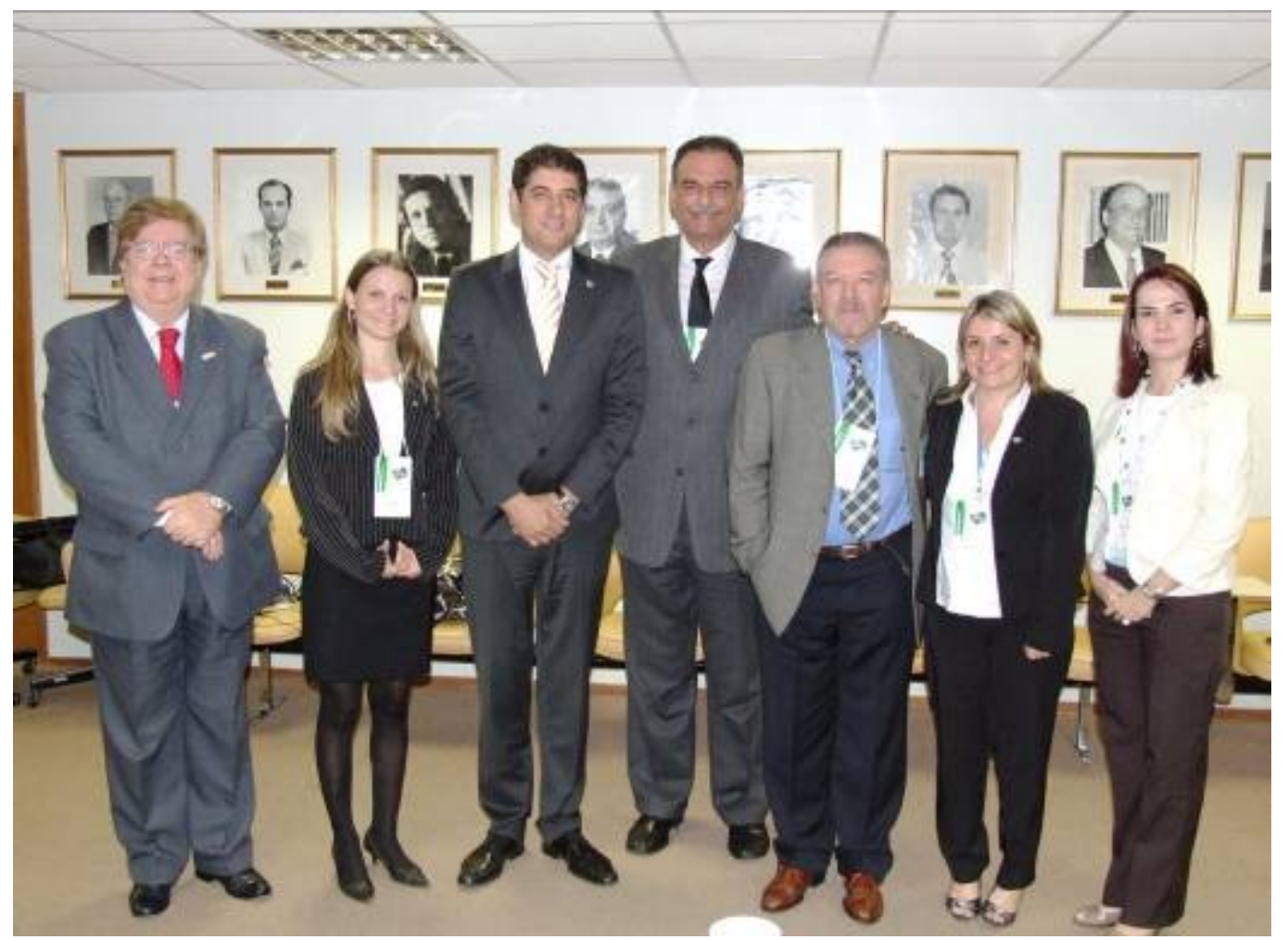

Da esquerda para direita: Gaspar Brandão, Cinthia Marques, Marcelo Pedroso, Ibrahim Tahtouh, Edmundo Monteiro, Maria Katavatis e Thais Del Ben. Crédito: Tony Maciel

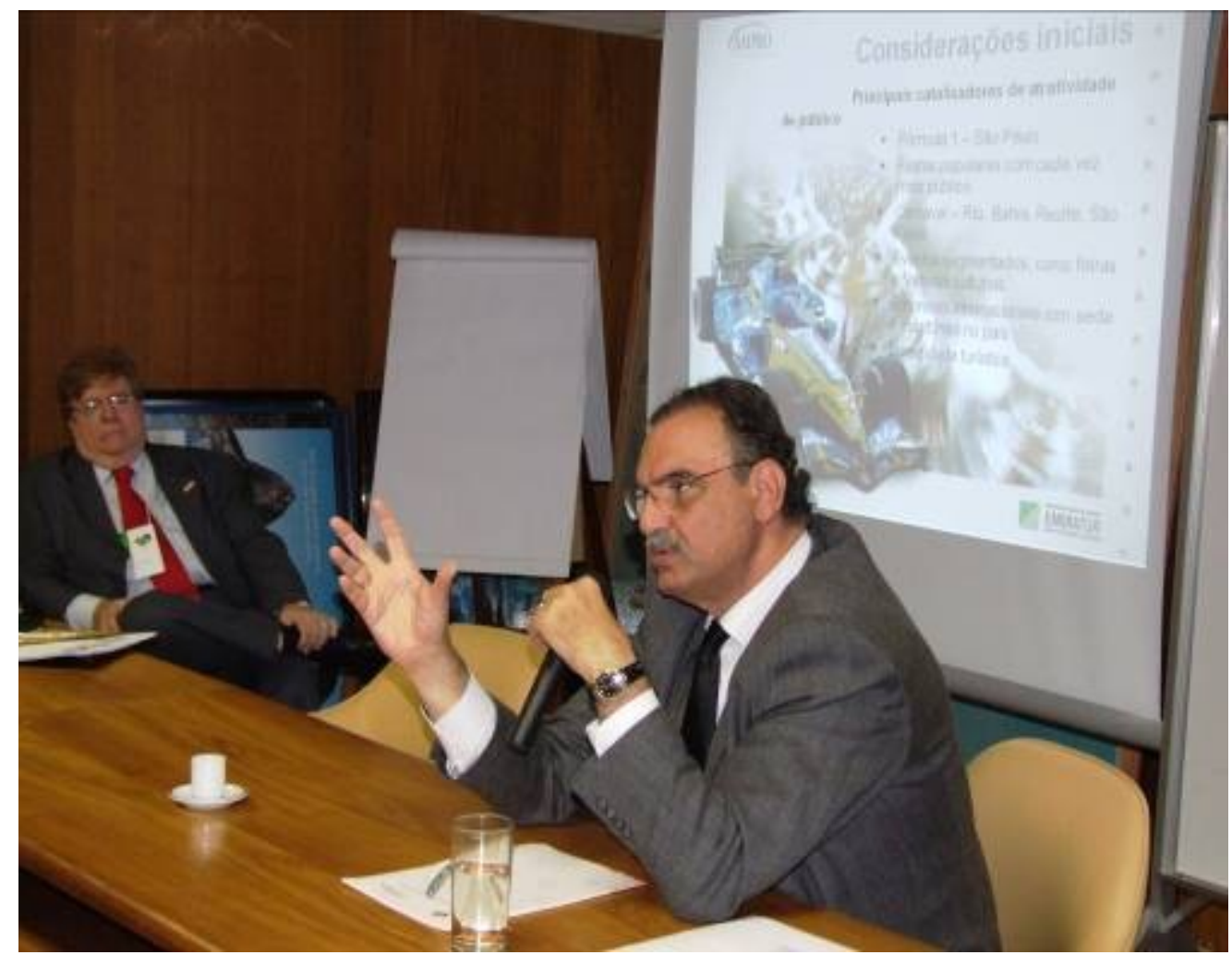

Sr. Ibrahim Tahtouh respondendo a questionamentos. Crédito: Tony Maciel 


\section{Anexo C: Lista das Principais Feiras de Turismo de Incentivo \\ $>$ Intenacionais \\ - CONFEX}

Data: fevereiro

A Confex é um encontro destinado somente aos profissionais do trade, organizadores de congressos, encontros, lançamento de produtos, viagens de incentivos e eventos especiais. O evento, que este ano celebrou sua $26^{a}$ edição foi o local ideal para os expositores trocarem informações, fazerem contatos profissionais e fecharem negócios.

A participação do Embratur nesta feira, nos últimos anos, foi de extrema importância por permitir ao trade local a constatação de que o Brasil além de promover segmento de negócios, eventos e incentivos também está totalmente capacitado e preparado para receber grandes grupos.

Perfil: Profissionais

Site do evento: http://www.international-confex.com/

Segmento: Negócios, eventos e incentivo

Local: Londres / Inglaterra

Público estimado: 15.000

- IMEX

Data: maio

A IMEX possui grande capacidade em promover encontros de incentivo com compradores qualificados da indústria turística mundial, reunindo mais de 3,000 expositores de 150 países e proporcionando seu contato por meio de um sistema de encontros pré-agendados de forma online.

O evento também oferece seminários e workshops organizados por renomadas associações e instituições que têm como principal objetivo identificar e apontar as principais inovações do ramo turístico. 
Perfil: Profissionais

Público estimado: 7.000

Site do evento: http://www.imex-frankfurt.com/

Segmento: Negócios, eventos e incentivo

Local: Frankfurt / Alemanha

- EMIF - European Meeting Industry Fair

Data: março

A EMIF - The European Meetings Industry Fair, evento que realizou sua $8^{a}$ edição no ano de 2009 e é destaque como feira de negócios, eventos e incentivos na região da Bélgica, Holanda e Luxemburgo.

A feira oferece a oportunidade de comparar novos produtos e serviços, a possibilidade de descobrir novas idéias, localidades e destinos e contato direto b2b (business to business) com mais de 400 fornecedores MICE (Meetings, Incentives, Congress and Exhibitions), além de seminários gratuitos. O evento possui uma plataforma que permite ao participante ficar atualizado quanto a novos produtos e serviços na Indústria de Turismo de Negócios.

Perfil: Profissionais

Site do evento: http://www.aboutemif.com/

Segmento: Negócios, Eventos e Incentivos

Local: Bruxelas / Bélgica

Público estimado: 4.000 visitantes

- Feria Internacional del Mercado de Reuniones e Incentivos de América Latina y el Caribe - FIEXPO Latino America

Data: Junho 
A FIEXPO é uma mostra que tem como objetivo a divulgação do potencial do mercado Latino Americano para a realização de eventos internacionais. Reúne os principais destinos turísticos deste mercado e conta com entrevistas diárias préprogramadas com os compradores internacionais possibilitando a realização de negócios com representantes de associações internacionais que realizam congressos por todo o continente.

Em sua $2^{\circ}$ edição, o evento já se constitui em uma excelente oportunidade para demonstração ao mundo do potencial, infra-estrutura e desenvolvimento dos serviços deste setor, criando um ambiente propício para a geração de contatos e um leque de opções para profissionais interessados em levar grupos corporativos e congressos para destinos da América do Sul.

Conforme dados divulgados pela organização da feira, em 2008 foram recebidos 528 compradores, resultando na realização de 1.359 reuniões e gerando aproximadamente 159 milhões de dólares na consolidação desses negócios. Esses participantes (compradores) são procedentes do Brasil, Argentina, Peru, Chile, Europa entre outros. De acordo com os perfis registrados, $18 \%$ são gestores de associações internacionais, 45\% gestores de associações na América Latina, 22\% corporativo e $15 \%$ agente de incentivos.

Perfil: Profissionais e Público Final

Site do evento: www.fiexpo-latam.com

Segmento: Negócios, eventos e incentivos

Local: Montevidéu - Uruguai

Público estimado: 600 pessoas

- MITM AMERICAS - Meetings \& Incentive Trade Market

Data: Novembro

Em sua 9a edição em 2009, a MITM Américas é um evento itinerante que visa promover destinos e serviços turísticos de empresas e organismos do continente americano, onde todos os tipos de compradores, organizadores de eventos e 
congressos, CVB's (Conventions \& Visitors Bureaux) e inclusive os expositores encontram-se com fornecedores de serviços e produtos turísticos, tanto públicos e privados. Focada em compradores, consumidores de viagens de incentivo e organizadores de convenções e congressos provenientes da América do Norte e Europa, funciona como um fórum interativo realizando a interação de expositores e compradores por meio de reuniões individuais previamente agendadas, sendo possível até 20 reuniões, de 15 minutos cada, por expositor. O Embratur participará pela $3^{\circ}$ vez do evento este ano. Em 2007, o Brasil sediou o evento e foi registrado um público de 197 profissionais.

Perfil: Profissionais

Site do evento: http://www.mitmamericas.com/

Segmento: Negócios, eventos e incentivos.

Público estimado: 300

- $\quad$ IT\&ME - The Motivation Show

Data: setembro

A IT\&ME é uma feira consolidado no cenário de eventos profissionais norteamericano voltado para o mercado de negócios, eventos e incentivo. O encontro destaca-se pela qualidade dos buyers (compradores), dos veículos especializados e dos expositores.

Em sua $68^{a}$ edição em 2009, serão convidados cerca de 2.500 entidades de classe, além de 10.000 buyers, ampliando a divulgação dos expositores e seus produtos diretamente aos compradores. A IT\&ME reúne os mais respeitados fornecedores de incentivo de mercadoria e serviços, conhecimento e incentivo de programas de viagens, produtos promocionais e conta com serviços de incentivo online objetivando maximizar oportunidades e assegurar a realização de negócios.

$\mathrm{Na}$ última edição o evento constatou a presença de mais de 500 expositores, representantes de 50 países. O Embratur participa desta feira há 14 anos.

Perfil: Profissionais 
Site do evento: www.motivationshow.com

Segmento: Negócios, eventos e incentivo.

Local: Chicago / EUA

Público estimado: 15.000 visitantes

- BTC International

Data: novembro

A BTC International, que em 2009 realizará a sua 25a edição em Roma, cidade considerada coração de encontros de negócios da Itália. Especializada no setor de negócios, eventos e incentivos, a feira oferece encontros pré-agendados de alta qualidade entre expositores e buyers, proporcionando maior liberdade para gerenciar sua participação no evento, além de ser uma ótima vitrine para avaliação das novas tendências e solicitações do mercado.

Perfil: Profissionais

Site do evento: www.btc.it

Segmento: Negócios, eventos e incentivos

Local: Roma/ Itália

Público estimado: 5.300

Nacionais

- LACIME: Latin America and Caribbean Incentive \& Meetings Exhibition

Data: junho

Esta feira foi especialmente desenvolvida para o mercado do turismo de incentivo, eventos e negócios que visa auxiliar as organizações no preparo de suas reuniões programa de conferências, viagens de negócios e campanhas de viagens de incentivo. 
A LACIME é o mais importante evento que apresenta a América Latina e o Caribe para a indústria mundial do turismo de eventos, congressos, incentivo e negócios. Mais de 250 empresas oferecem uma grande variedade de produtos e serviços para profissionais do mercado.

Local: São Paulo

Freqüência: Anual

Site do evento: www.lacimexpo.com

- LACTTE - Encontro Latino-Americano de Viagens Corporativas e Tecnologia

Data: janeiro ou fevereiro

A ABGEV (Associação Brasileira de Gestores de Viagens Corporativas) realiza anualmente o evento LACTTE em parceria com a NBTA (National Business Travel Association, EUA). Esta feira reúne o principal trade do mercado de viagens corporativas, dentre esses redes hoteleiras, companhias aéreas, agencias de viagens e incentivos, organizadora de eventos, empresas de tecnologia, etc. Local: São Paulo

Freqüência: Anual

Site do evento: www.abgev.org.br

- EBEI - Encontro Brasileiro de Empresas de Incentivos

Data: dezembro

O EBEI acontece dentro de um grande evento denominado Semana Nacional dos Eventos e traz para a discussão temas de interesse comum às empresas de viagens, de produtos de premiação e de marketing de incentivo. Se destina a empresários e profissionais de Marketing Promocional, empresas de incentivo, fornecedores, clientes, professores universitários e estudantes.

Local: São Paulo

Freqüência: Anual Site do evento: http://www.semanaeventos.com.br/ 